Supporting Information for

\title{
Reactive Ligand Influence on Initiation in Phenylene Catalyst-Transfer Polymerization
}

Ariana O. Hall, ${ }^{a}$ Se Ryeon Lee, ${ }^{a}$ Jacob W. G. Bloom, ${ }^{b}$ Andrea N. Bootsma, ${ }^{b}$ Steven E. Wheeler, ${ }^{b}$ and Anne J. McNeil ${ }^{\mathrm{a},}$

a Department of Chemistry and Macromolecular Science and Engineering Program, University of Michigan, 930 North University Avenue, Ann Arbor, Michigan 48109-1055

${ }^{b}$ Department of Chemistry, Texas A\&M University, PO Box 30012, College Station, Texas, 77842-3012

\section{Contents}

Page

I. Materials

S2

II. General Experimental

S2

III. Synthetic Procedures

S4

IV. Attempted Synthesis of [1,2-bis(diphenylphosphino)ethane](2-butenyl)nickel(II) Chloride S10

V. NMR Spectra

S13

VI. Initiation Rate Studies

S24

VII. Polymerization

S37

VIII. MALDI-TOF-MS data

S44

IX. Computational Studies

S49

X. References

S99 


\section{Materials}

iPrMgCl (2M in THF) was purchased in $100 \mathrm{~mL}$ quantities from Aldrich. Bis(cyclooctadiene)nickel $\left(\mathrm{Ni}(\mathrm{cod})_{2}\right)$ and 1,2-bis(diphenylphosphino)ethane (dppe) were purchased from Strem. All other reagent grade materials and solvents were purchased from Aldrich, Acros, EMD, or Fisher and used without further purification unless otherwise noted. THF was dried and deoxygenated using an Innovative Technology (IT) solvent purification system composed of activated alumina, copper catalyst, and molecular sieves. $\mathrm{N}$-Bromosuccinimide (NBS) was recrystallized from hot water and dried over $\mathrm{P}_{2} \mathrm{O}_{5}$. Flash chromatography was performed on SiliCycle silica gel $(40-63 \mu \mathrm{m})$ and thin layer chromatography was performed on Merck TLC plates pre-coated with silica gel 60 F254. Compounds $\mathbf{S 2},{ }^{1}$ and $\mathbf{2} \mathbf{b}-\mathbf{2} \mathbf{f}^{2}$ were prepared from modified literature procedures.

\section{General Experimental}

NMR Spectroscopy: Unless otherwise noted, ${ }^{1} \mathrm{H},{ }^{13} \mathrm{C},{ }^{19} \mathrm{~F}$ and ${ }^{31} \mathrm{P}$ NMR spectra for all compounds were acquired at it in $\mathrm{CD}_{2} \mathrm{Cl}_{2}$ or $\mathrm{CDCl}_{3}$ on a Varian vnmrs 700 operating at $700,176,660$, and $283 \mathrm{MHz}$ and Varian vnmrs 500 operating at $500,126,470$, and $202 \mathrm{MHz}$, respectively. For ${ }^{1} \mathrm{H}$ and ${ }^{13} \mathrm{C}$ spectra in deuterated solvents, the chemical shift data are reported in units of $\delta(\mathrm{ppm})$ relative to tetramethylsilane (TMS) and referenced with residual solvent. ${ }^{19} \mathrm{~F}$ NMR spectra were reported relative to $\mathrm{CFCl}_{3}$ and ${ }^{31} \mathrm{P}$ NMR spectra were relative to $\mathrm{H}_{3} \mathrm{PO}_{4}$. For ${ }^{1} \mathrm{H}$, ${ }^{19} \mathrm{~F}$ and ${ }^{31} \mathrm{P}$ NMR spectra in non-deuterated THF, the chemical shift data are reported in units of $\delta(\mathrm{ppm})$ and referenced with the THF peak at $3.58 \mathrm{ppm}$ in the ${ }^{1} \mathrm{H}$ NMR spectrum which is then applied to all nuclei. Multiplicities are reported as follows: singlet (s), doublet (d), doublet of doublets (dd), triplet $(\mathrm{t})$, quartet (q), multiplet (m), broad resonance (br), and apparent triplet (at).

Mass Spectrometry: HRMS data were obtained on a Micromass AutoSpec Ultima Magnetic Sector mass spectrometer.

IR Spectroscopy: Samples were recorded using a Mettler Toledo ReactIR iC10 fitted with a Mercury Cadmium Telluride (MCT) detector, and AgX probe $(9.5 \mathrm{~mm} \times 1.5 \mathrm{~mm})$ with a SiComp tip. The spectra were processed using iclR 4.0 software and raw absorbances were exported into Microsoft Excel or Sigma Plot 10 or 13 for analysis.

MALDI-TOF MS: MALDI-TOF mass spectra were recorded using a Bruker AutoFlex Speed in linear or reflectron mode at masses between 5000 and 15000. The matrix trans-2-[3-(4-tertbutylphenyl)-2-methyl-2-propenylidene]malononitrile (DCTB), was prepared at a concentration of $0.1 \mathrm{M}$ in $\mathrm{CHCl}_{3}$. The matrix sinapic acid was prepared as a saturated solution in a mixture of 30/70 ( $\mathrm{v} / \mathrm{v}) \mathrm{MeCN} / \mathbf{0 . 1 \%}$ TFA in $\mathrm{H}_{2} \mathrm{O}$. The instrument was calibrated with a mixture of peptides in the sinapic acid matrix or with a sample of polyphenylene with $\mathrm{H} / \mathrm{Br}$ endgroups. The polymer sample was dissolved in THF or $\mathrm{CH}_{2} \mathrm{Cl}_{2}$ to obtain a approx. $1 \mathrm{mg} / \mathrm{mL}$ solution. A $2.5 \mu \mathrm{L}$ aliquot of polymer solution was mixed with $2.5 \mu \mathrm{L}$ of the DCTB or sinapic acid matrix solution. This mixture $(1 \mu \mathrm{L})$ was placed on the target plate and then air-dried. The data was analyzed using flexAnalysis and the percentages refer to the relative area ratios for each DP. 
Gel-Permeation Chromatography: Polymer molecular weights were determined by comparison with polystyrene standards (Varian, EasiCal PS-2 MW 580-377,400) on a Waters 1515 HPLC instrument equipped with Waters Styrage ${ }^{\circledR}(7.8 \times 300 \mathrm{~mm})$ THF HR 0.5, THF HR 1, and THF HR 4 type columns in sequence and analyzed with Waters 2487 dual absorbance detector (254 nm) or on a Malvern Viscotek GPCMax VE2001 equipped with two Viscotek LT-5000L $8 \mathrm{~mm}$ (ID) $\times$ $300 \mathrm{~mm}$ (L) columns and analyzed with Viscotek TDA 305 (with R.I., UV-PDA Detector Model 2600 (190-500 nm), RALS/LALS, and viscometer). Samples were dissolved in THF (with mild heating) and passed through a $0.2 \mu \mathrm{m}$ PTFE filter prior to analysis.

Titrations of the Grignard Reagents: An accurately weighed sample of salicylaldehyde phenylhydrazone $^{3}$ (typically between 290-310 mg) was dissolved in $5.00 \mathrm{~mL}$ of THF. A $0.50 \mathrm{~mL}$ aliquot of this solution was stirred at rt while $\mathrm{ArMgCl}$ was added dropwise using a $500 \mu \mathrm{L}$ syringe. The initial solution is yellow and turns bright orange at the end-point.

Statistical Analysis: Reported quantitative data represents the average of 2-3 experiments and the error bars represent standard deviation. 


\section{Synthetic Procedures}

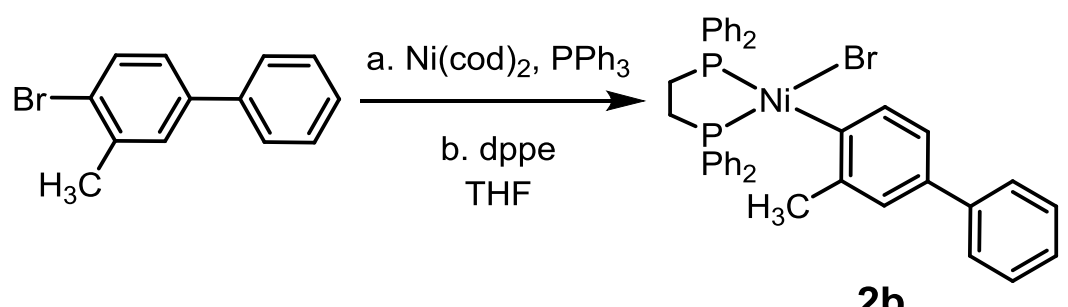

[1,2-bis(diphenylphosphino)ethane](2-methylbiphenyl)nickel(II) bromide (2d). In a glovebox, a $20 \mathrm{~mL}$ vial was equipped with a stir bar. Sequentially, Ni(cod) $)_{2}(83.5 \mathrm{mg}, 0.310 \mathrm{mmol}$, 1.00 equiv), $\mathrm{PPh}_{3}$ (161 mg, $0.615 \mathrm{mmol}, 2.00$ equiv) and THF (2 mL) were added. The solution was stirred for $5 \mathrm{~min}$ and 4-bromo-3-methylbiphenyl ( $86 \mathrm{mg}, 0.35 \mathrm{mmol}, 1.1$ equiv) and THF (2 $\mathrm{mL}$ ) were added. The solution was stirred at rt for $2 \mathrm{~h}$. To the deep red solution, dppe (134 $\mathrm{mg}$, $0.335 \mathrm{mmol}, 1.10$ equiv) and THF (2 mL) were added. The solution was stirred for another $2 \mathrm{~h}$. The orange solution was concentrated in vacuo until approx. $1 \mathrm{~mL}$ of solution was left. Addition of hexanes $(18 \mathrm{~mL})$ led to a yellow orange precipitate. The solid was filtered and washed with hexanes $(20 \mathrm{~mL})$. The resulting solid was recrystallized from approx. 1/3 (v/v) THF/hexanes (approx. $20 \mathrm{~mL}$ ), to give $106 \mathrm{mg}$ of $\mathbf{2 d}$ as an orange solid (50\% yield). Elemental Analysis: Calcd for $\mathrm{C}_{39} \mathrm{H}_{35} \mathrm{BrNiP}_{2}$, C, 66.51; $\mathrm{H}, 5.01$; found $\mathrm{C}, 66.57 ; \mathrm{H}, 5.16$.

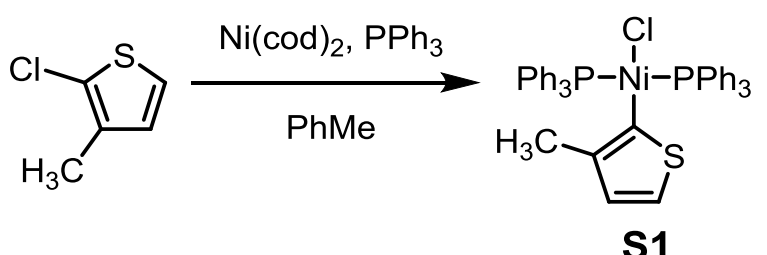

[Bis(triphenylphosphine)](3-methylthiophene)nickel(II) chloride (S1). A $20 \mathrm{~mL}$ vial was equipped with a stir bar in the glovebox. Sequentially, $\mathrm{Ni}(\operatorname{cod})_{2}(139 \mathrm{mg}, 0.506 \mathrm{mmol}, 1.00$ equiv), $\mathrm{PPh}_{3}$ (262 mg, $1.00 \mathrm{mmol}, 1.98$ equiv), toluene (4 mL), and 2-chloro-3-methylthiophene (82 $\mu \mathrm{L}$, $0.75 \mathrm{mmol}, 1.5$ equiv) were added. The solution was stirred at $\mathrm{rt}$ for $30 \mathrm{~min}$ and turned from dark red homogeneous solution to orange heterogeneous mixture. The reaction was removed from the glovebox. Addition of hexanes $(30 \mathrm{~mL})$ led to an orange precipitate. The solid was filtered and washed with hexanes $(20 \mathrm{~mL})$ and cold $\mathrm{MeOH}(5 \mathrm{~mL})$. The resulting solid was recrystallized from $1 / 3(\mathrm{v} / \mathrm{v}) \mathrm{THF} /$ hexanes (approx. $20 \mathrm{~mL}$ ), to give $299 \mathrm{mg}$ of $\mathbf{S} 1$ as an orange solid (84\% yield). Elemental analysis: Calcd for $\mathrm{C}_{41} \mathrm{H}_{35} \mathrm{CINiP}{ }_{2} \mathrm{~S}, \mathrm{C}, 68.79 ; \mathrm{H}, 4.93$; Found $\mathrm{C}, 68.49 ; \mathrm{H}, 4.88$. 


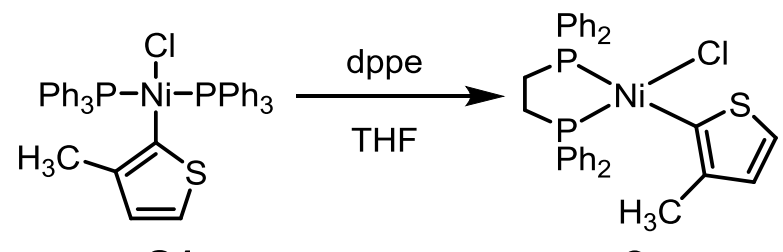

S1

2c

[1,2-bis(diphenylphosphino)ethane](3-methylthiophene)nickel(II) chloride (2c). In a glovebox, a $20 \mathrm{~mL}$ vial was equipped with a stir bar. Sequentially, $\mathbf{S 1}(144 \mathrm{mg}, 0.200 \mathrm{mmol}, 1.00$ equiv), dppe ( $89 \mathrm{mg}, 0.22 \mathrm{mmol}, 1.1$ equiv), and THF ( $4 \mathrm{~mL}$ ) were added. The solution was stirred at $\mathrm{rt}$ for $1 \mathrm{~h}$. The heterogeneous orange solution was concentrated in vacuo until approx. $1 \mathrm{~mL}$ of solution remained. Addition of hexanes $(18 \mathrm{~mL})$ led to an orange precipitate. The solid was collected by vacuum filtration and washed with hexanes $(20 \mathrm{~mL})$. The resulting solid was recrystallized from $1 / 3(\mathrm{v} / \mathrm{v}) \mathrm{THF} /$ hexanes (approx. $20 \mathrm{~mL}$ ), to give $78 \mathrm{mg}$ of $2 \mathrm{c}$ as an orange solid (66\% yield). The product is air-sensitive and prone to decomposition.<smiles>Cc1csc2ccccc12</smiles>

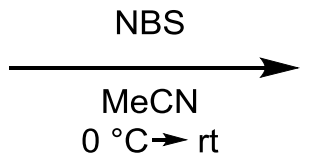<smiles>Cc1c(Br)sc2ccccc12</smiles>

S2

2-bromo-3-methylbenzo[b]thiophene (S2). A $10 \mathrm{~mL}$ round-bottom flask was equipped with a stir bar and cooled to $0{ }^{\circ} \mathrm{C}$ with an ice-water bath. Sequentially, 3-methylbenzothiophene (402 $\mu \mathrm{L}$, $3.00 \mathrm{mmol}, 1.00$ equiv), MeCN ( $3.5 \mathrm{~mL}$ ), and NBS (561 mg, $3.15 \mathrm{mmol}, 1.05$ equiv) were added. The ice-water bath was removed after $5 \mathrm{~min}$ and the solution was stirred at it for $30 \mathrm{~min}$. The reaction was quenched with water $(15 \mathrm{~mL})$ and extracted with $\mathrm{CH}_{2} \mathrm{Cl}_{2}(3 \times 10 \mathrm{~mL})$. The combined organic layers were dried over $\mathrm{MgSO}_{4}$, filtered, and concentrated in vacuo. The resulting oil was purified via silica gel chromatography, using $100 \%$ hexanes as the eluent, to give $618 \mathrm{mg}$ of $\mathbf{S 2}$ as a clear liquid (91\% yield). HRMS (EI): [M+] Calcd for $\mathrm{C}_{9} \mathrm{H}_{7} \mathrm{BrS}, 225.9452$; found, 225.9450.<smiles>Cc1c(Br)sc2ccccc12</smiles>

S2

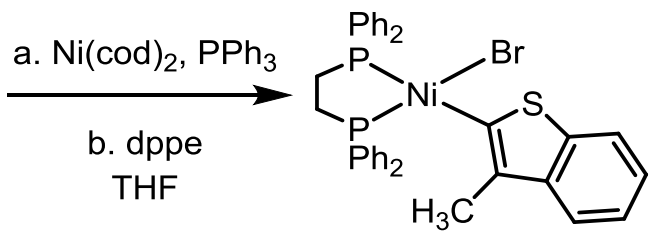

2d

[1,2-bis(diphenylphosphino)ethane](3-methylbenzo[b]thiophene)nickel(II) bromide (2d). A $20 \mathrm{~mL}$ vial was equipped with a stir bar in the glovebox. Sequentially, Ni(cod) 2 ( $82 \mathrm{mg}, 0.30 \mathrm{mmol}$, 1.0 equiv), $\mathrm{PPh}_{3}(158 \mathrm{mg}, 0.602 \mathrm{mmol}, 2.00$ equiv) and THF $(3 \mathrm{~mL})$ were added. The solution was stirred for $5 \mathrm{~min}$ and $\mathbf{S 2}(1.04 \mathrm{~mL}, 0.460 \mathrm{mmol}, 1.5$ equiv) and THF (1 mL) were added. The 
solution was stirred at rt for $1.5 \mathrm{~h}$. To the deep red solution, dppe $(2.0 \mathrm{~mL}, 0.17 \mathrm{M}$ in THF, 0.33 mmol, 1.1 equiv) were added. The solution was stirred for another $2 \mathrm{~h}$. The orange solution was concentrated in vacuo until approx. $1 \mathrm{~mL}$ of solution was left. Addition of hexanes $(18 \mathrm{~mL})$ led to a yellow precipitate. The solid was filtered and washed with hexanes $(5 \mathrm{~mL})$. The resulting solid was recrystallized from approx.1/3 (v/v) THF/hexanes (approx. $20 \mathrm{~mL}$ ), to give $133 \mathrm{mg}$ of $\mathbf{2 d}$ as a dark orange solid (65\% yield). Elemental Analysis: Calcd for $\mathrm{C}_{35} \mathrm{H}_{31} \mathrm{BrNiP}_{2} \mathrm{~S}, \mathrm{C}, 61.44 ; \mathrm{H}, 4.57$; Found C, 61.33; H, 4.68.

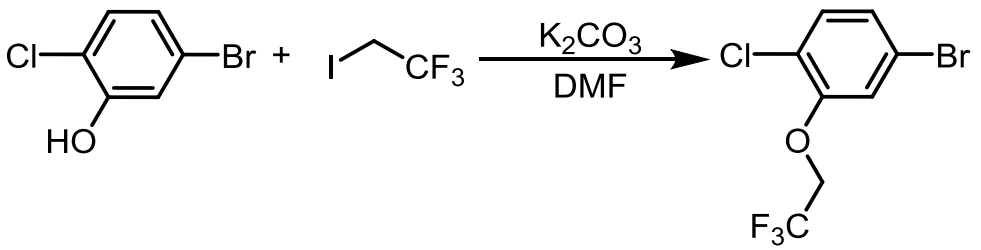

S3

4-bromo-1-chloro-2-(2,2,2-trifluoroethoxy)benzene (S3). A $250 \mathrm{~mL}$ bomb flask was equipped with a stir bar. Sequentially, 5-bromo-2-chlorophenol (3.41 g, $16.4 \mathrm{mmol}, 1.00$ equiv), $\mathrm{K}_{2} \mathrm{CO}_{3}(6.80$ g, $49.2 \mathrm{mmol}, 3.00$ equiv), DMF (35 mL), and 2-iodo-1,1,1-trifluoroethane $(6.5 \mathrm{~mL}, 65 \mathrm{mmol}, 4.0$ equiv) were added. The mixture was stirred for $6 \mathrm{~d}$ at $65^{\circ} \mathrm{C}$. The mixture was poured into water $(70 \mathrm{~mL})$ and extracted with $\mathrm{CH}_{2} \mathrm{Cl}_{2}(3 \times 50 \mathrm{~mL})$. The organic layers were combined, washed with brine $(25 \mathrm{~mL})$, dried over $\mathrm{MgSO}_{4}$, and concentrated in vacuo. The resulting oil was purified by silica gel chromatography using 5:95 (v/v) $\mathrm{CH}_{2} \mathrm{Cl}_{2} /$ hexanes as the eluent to give $2.26 \mathrm{~g}$ of $\mathrm{S} 3$ as a colorless oil (48\% yield). HRMS (El): [M+] Calcd for $\mathrm{C}_{8} \mathrm{H}_{5} \mathrm{BrClF}_{3} \mathrm{O}, 287.9164$; found, 287.9170.
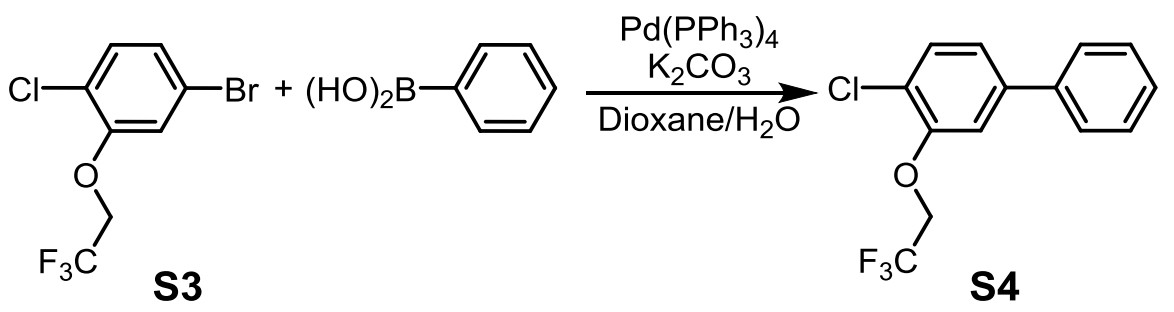

4-chloro-3-(2,2,2-trifluoroethoxy)-1,1'-biphenyl (S4). In a glovebox under a $\mathrm{N}_{2}$ atmosphere, a $25 \mathrm{~mL}$ Schlenk flask was equipped with a stir bar and charged with $\mathrm{Pd}\left(\mathrm{PPh}_{3}\right)_{4}(139 \mathrm{mg}, 0.120$ $\mathrm{mmol}, 0.030$ equiv). The flask was sealed with a septum, removed from the glovebox and charged with phenyl boronic acid (740 mg, $6.00 \mathrm{mmol}, 1.50$ equiv) and $\mathrm{K}_{2} \mathrm{CO}_{3}$ (1.66 g, $12.0 \mathrm{mmol}, 3.00$ equiv). A solution of 1,4-dioxane and water (9:1) was sparged with $\mathrm{N}_{2}$ for $30 \mathrm{~min}$, and $8 \mathrm{~mL}$ was added to the Schlenk flask. Then, S3 (1.18 g, $4.07 \mathrm{mmol}, 1.00$ equiv) was dissolved in the dioxane/water solution $(5.0 \mathrm{~mL})$ and added to the reaction mixture. The reaction mixture was heated to $90{ }^{\circ} \mathrm{C}$ overnight. The reaction was quenched with satd. aq. $\mathrm{NaHCO}_{3}(30 \mathrm{~mL})$ and extracted with EtOAc $(3 \times 30 \mathrm{~mL})$. The organic layers were combined and washed with brine $(25$ $\mathrm{mL}$ ), dried over $\mathrm{MgSO}_{4}$, and concentrated in vacuo. The product was purified by silica gel chromatography using 5/95 (v/v) EtOAc/hexanes to give $866 \mathrm{mg}$ of $\mathbf{S 4}$ as a colorless oil, which 
slowly crystallized into a white solid (76\% yield). HRMS (El): $[\mathrm{M}+]$ Calcd for $\mathrm{C}_{14} \mathrm{H}_{10} \mathrm{ClF}_{3} \mathrm{O}$, 286.0372; found, 286.0383 .<smiles>FC(F)(F)COc1cc(-c2ccccc2)ccc1N(P)P(Cl)N(CC(F)(F)F)c1ccc(-c2ccccc2)cc1OCC(F)(F)F</smiles>

S4

S5

[Bis(triphenylphosphine)](3-(2,2,2-trifluoroethoxy)-1,1'-biphenyl)nickel(II) chloride (S5). In a glovebox, $\mathrm{Ni}(\mathrm{cod})_{2}(68.8 \mathrm{mg}, 0.250 \mathrm{mmol}, 1.00$ equiv) and triphenylphosphine (131 $\mathrm{mg}, 0.490$ mmol, 2.00 equiv) and $\mathbf{S 4}$ (94.6 $\mathrm{mg}, 0.330 \mathrm{mmol}, 1.30$ equiv) were dissolved in toluene $(2.5 \mathrm{~mL})$ in a $20 \mathrm{~mL}$ vial. The reaction mixture was stirred at $\mathrm{rt}$ for $2.5 \mathrm{~h}$, then concentrated until approx. $0.5 \mathrm{~mL}$ toluene remained. Hexanes (approx. $15 \mathrm{~mL}$ ) was added, and the yellow precipitate was isolated by vacuum filtration, giving $149 \mathrm{mg}$ of a yellow powder (68\% crude yield) which was carried on without further purification.<smiles>FC(F)(F)COc1cc(-c2ccccc2)ccc1N(CC(F)(F)F)P(c1ccccc1)(c1ccccc1)(c1ccccc1)N(c1ccccc1)P(Cl)c1ccccc1</smiles>

\section{[1,2-bis(diphenylphosphino)ethane](3-(2,2,2-trifluoroethoxy)-1,1'-biphenyl)nickel(II)}

chloride (2e). In a glovebox, S5 (149 mg, $0.170 \mathrm{mmol}, 1.00$ equiv) and dppe (76.5 mg, 0.187 mmol, 1.10 equiv) were dissolved in THF $(2.5 \mathrm{~mL})$ in a $20 \mathrm{~mL}$ vial. The solution was stirred at $\mathrm{rt}$ for $1 \mathrm{~h}$, then concentrated until approx. $0.5 \mathrm{~mL}$ THF remained. Hexanes (approx. $15 \mathrm{~mL}$ ) was added, and the yellow precipitate was isolated by vacuum filtration. The product was recrystallized from approx. 1/3 (v/v) THF/hexanes (approx. $20 \mathrm{~mL})$, giving $100 \mathrm{mg}$ of a yellow powder $(79 \%$ yield.) Elemental Analysis: Calcd for $\mathrm{C}_{40} \mathrm{H}_{34} \mathrm{ClF}_{3} \mathrm{NiOP}_{2}, \mathrm{C}, 64.59 ; \mathrm{H}, 4.61$; Found $\mathrm{C}, 64.37 ; \mathrm{H}, 4.65$. 


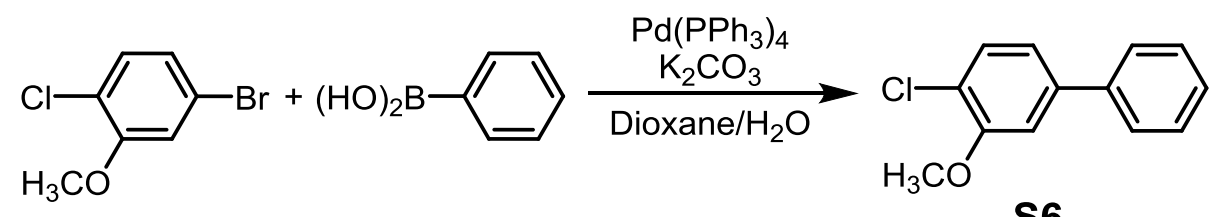

56

4-chloro-3-methoxy-1,1'-biphenyl (S6). A $25 \mathrm{~mL}$ Schlenk flask was equipped with a stir bar in the glovebox and charged with $\mathrm{Pd}\left(\mathrm{PPh}_{3}\right)_{4}(104 \mathrm{mg}, 0.0900 \mathrm{mmol}, 0.0600$ equiv). The Schlenk flask was then removed from the glovebox and charged with phenylboronic acid (274 mg, 2.30 mmol, 1.50 equiv) and $\mathrm{K}_{2} \mathrm{CO}_{3}(622 \mathrm{mg}, 4.50 \mathrm{mmol}, 3.00$ equiv). A solution of 1,4-dioxane and water (9:1) was sparged with $\mathrm{N}_{2}$ for $30 \mathrm{~min}$, and $7 \mathrm{~mL}$ were added to the Schlenk flask. Then, 4bromo-1-chloro-2-methoxy-benzene (332 mg, $1.50 \mathrm{mmol}, 1.00$ equiv) was dissolved in the dioxane/water solution $(5 \mathrm{~mL})$ and added to the reaction mixture. The reaction mixture was heated to $90{ }^{\circ} \mathrm{C}$ for $6 \mathrm{~h}$. The reaction was quenched with saturated $\mathrm{NH}_{4} \mathrm{Cl}(35 \mathrm{~mL})$, extracted with EtOAc $(3 \times 35 \mathrm{~mL})$, washed with brine $(35 \mathrm{~mL})$, dried over $\mathrm{MgSO}_{4}$, and concentrated in vacuo. The product was purified by silica gel chromatography using 10/90 (v/v) toluene/hexanes to give 232 mg of a colorless oil (71\% yield). HRMS (El): [M+] Calcd for $\mathrm{C}_{13} \mathrm{H}_{11} \mathrm{ClO}$, 218.0498; found, 286.0500 .<smiles>COc1cc(-c2ccccc2)ccc1Cl</smiles>

56

S7

[Bis(triphenylphosphine)](3-methoxy-1,1'-biphenyl)nickel(II) chloride (S7). In the glovebox, $\mathrm{Ni}(\mathrm{cod})_{2}$ (138 mg, $0.502 \mathrm{mmol}, 1.0$ equiv), and triphenyl phosphine $\left(\mathrm{Ph}_{3} \mathrm{P}\right)(262 \mathrm{mg}, 1.00 \mathrm{mmol}$, 2.0 equiv) were dissolved in THF ( $3 \mathrm{~mL})$ in a $20 \mathrm{~mL}$ vial with stirring. In a separate $4 \mathrm{~mL}$ vial, 1 chloro-2-methoxy-4-phenyl-benzene (142 mg, $0.650 \mathrm{mmol}, 1.3$ equiv) was dissolved in THF (2 $\mathrm{mL}$ ). This solution was then added to the vial containing the $\mathrm{Ni} / \mathrm{Ph}_{3} \mathrm{P}$ and stirred at rt for $4 \mathrm{~h}$, during which time a yellow precipitate formed. The solvent was removed under vacuum until approx. 0.5 $\mathrm{mL}$ remained. Hexanes (approx. $15 \mathrm{~mL}$ ) were then added, and the yellow precipitate was collected by vacuum filtration, giving $157 \mathrm{mg}$ of $\mathbf{S 7}$ as a yellow powder (79\% crude yield). The product was used immediately without further purification. 


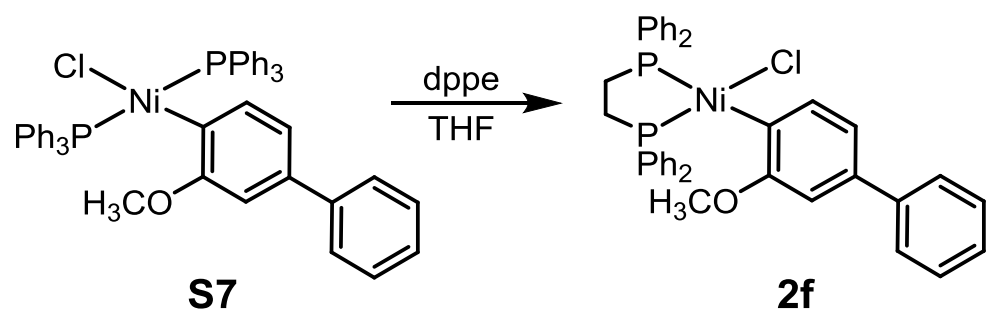

[1,2-bis(diphenylphosphino)ethane](3-methoxy-1,1'-biphenyl)nickel(II) chloride (2f). In a glovebox, in a $20 \mathrm{~mL}$ vial, $\mathbf{S 7}$ (157 mg, $0.196 \mathrm{mmol}, 1.0$ equiv) and dppe (94 mg, $0.24 \mathrm{mmol}, 1.2$ equiv) were dissolved in THF ( $2.5 \mathrm{~mL})$ in a $20 \mathrm{~mL}$ vial. The reaction mixture was stirred at $\mathrm{rt}$ for 1 h. (Note: a yellow precipitate was observed after 5 min.) After $1 \mathrm{~h}$, hexanes (approx. $15 \mathrm{~mL}$ ) was added, and the solution was cooled in a freezer at $-30^{\circ} \mathrm{C}$ overnight. The product was collected by vacuum filtration, giving $100 \mathrm{mg}$ of $\mathbf{2 f}$ as a yellow powder (59\% yield). Elemental Analysis: Calcd for $\mathrm{C}_{39} \mathrm{H}_{35} \mathrm{CINiOP}_{2}, \mathrm{C}, 69.31 ; \mathrm{H}, 5.22$; Found C, 67.96; H, 5.22. 


\section{Attempted Synthesis of [1,2-bis(diphenylphosphino)ethane](2-butenyl)nickel(II) Chloride}

Precatalyst synthetic procedure:

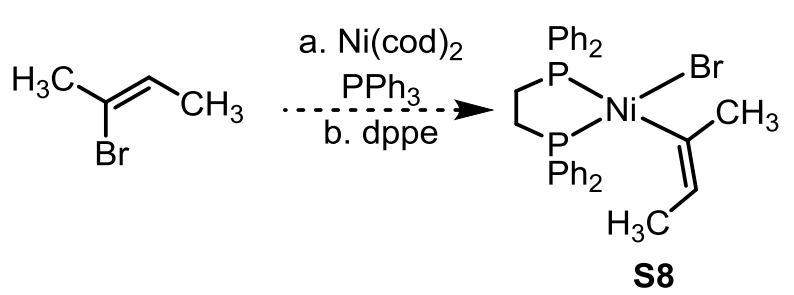

[1,2-bis(diphenylphosphino)ethane](2-butenyl)nickel(II) chloride (S8). In a glovebox, $\mathrm{Ni}(\mathrm{cod})_{2}(37.1 \mathrm{mg}, 0.125 \mathrm{mmol})$ and $\mathrm{PPh}_{3}(76.2 \mathrm{mg}, 0.250 \mathrm{mmol})$ were dissolved in THF $(1.0 \mathrm{~mL})$. In a separate vial, $Z$-2-bromo-2-butene $(24 \mu \mathrm{L}, 0.24 \mathrm{mmol})$ was dissolved in THF $(0.2 \mathrm{~mL})$, and the vial was sealed with a septum. The Ni solution $\left(0.80 \mathrm{~mL}\right.$, containing $0.10 \mathrm{mmol} \mathrm{Ni}(\operatorname{cod})_{2}$ and $0.20 \mathrm{mmol} \mathrm{PPh}_{3}$ ) was transferred to a J. Young NMR tube which was sealed with a septum and removed from the glovebox along with the vial containing Z-2-bromo-2-butene. The alkene solution $\left(0.10 \mathrm{~mL}, 0.12 \mathrm{mmol}, 1.2\right.$ equiv relative to $\left.\mathrm{Ni}(\operatorname{cod})_{2}\right)$ was added to the NMR tube, and a ${ }_{31} \mathrm{P}$ NMR spectrum was immediately acquired, showing $\mathrm{Ni}\left(\mathrm{PPh}_{3}\right)_{2}(\mathrm{cod})$ and a singlet at $20 \mathrm{ppm}$. A second ${ }^{31} \mathrm{P}$ NMR spectrum was acquired 5 min later, showing formation of several other peaks, as well as $\mathrm{Ni}\left(\mathrm{PPh}_{3}\right)_{2}(\mathrm{cod})$. After $1 \mathrm{hr}$, another ${ }^{31} \mathrm{P} \mathrm{NMR}$ spectrum was acquired, showing complete consumption of $\mathrm{Ni}\left(\mathrm{PPh}_{3}\right)_{2}(\mathrm{cod})$. Then, a solution of dppe in THF $(0.20 \mathrm{~mL}, 0.57 \mathrm{M}, 1.1$ equiv) was added and a final ${ }^{31} \mathrm{P}$ NMR spectrum was acquired, showing primarily $\mathrm{Ni}(\mathrm{dppe})_{2}$. The product was analyzed by GCMS, showing a peak with $\mathrm{m} / \mathrm{z}=110$, the mass of 3,4-dimethylhexa-2,4-diene (the expected organic product from a ligand disproportionation reaction followed by reductive elimination). 


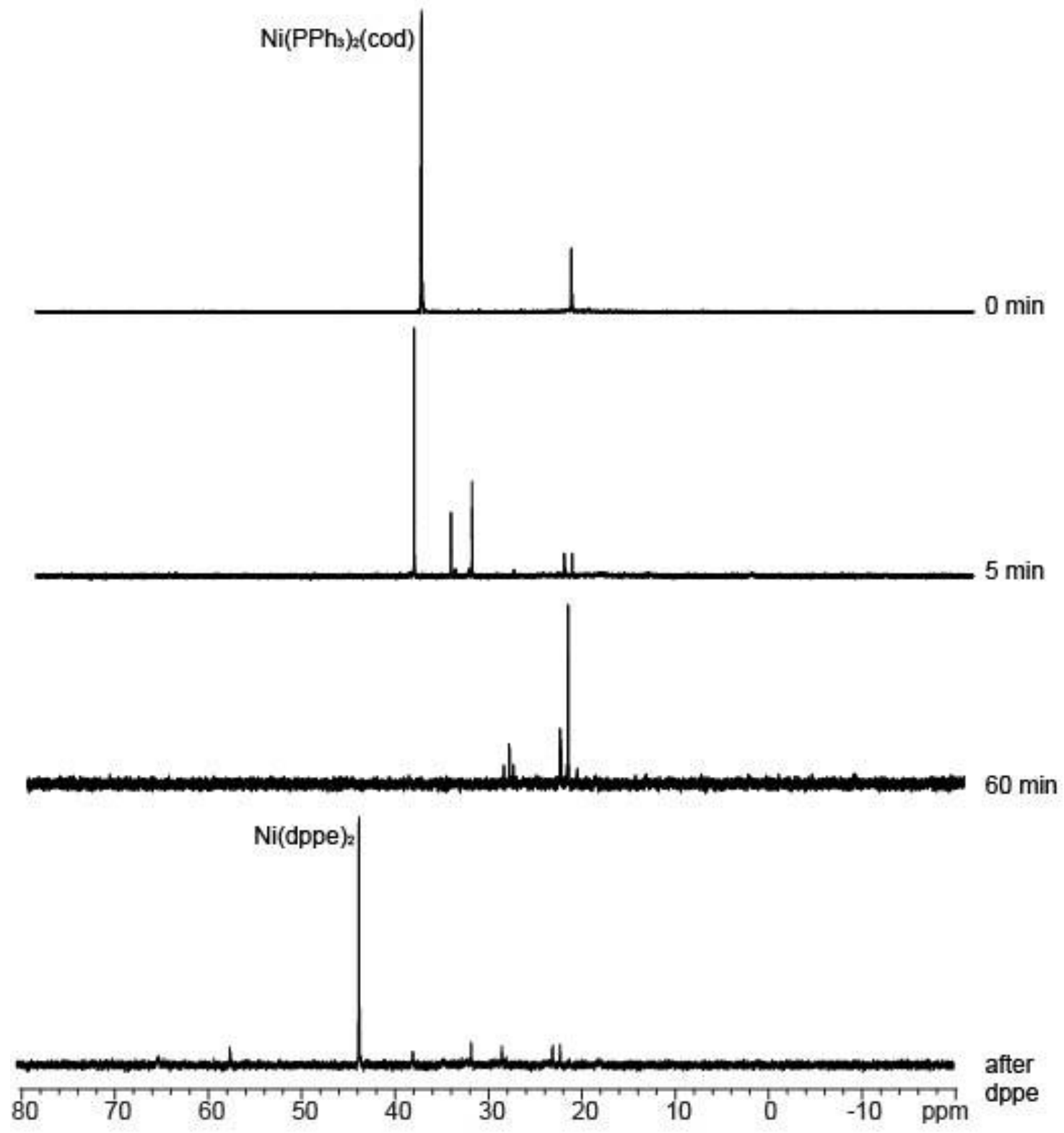

Figure S1. ${ }^{31} \mathrm{P}$ NMR spectra acquired during the attempted synthesis of S8 
a.
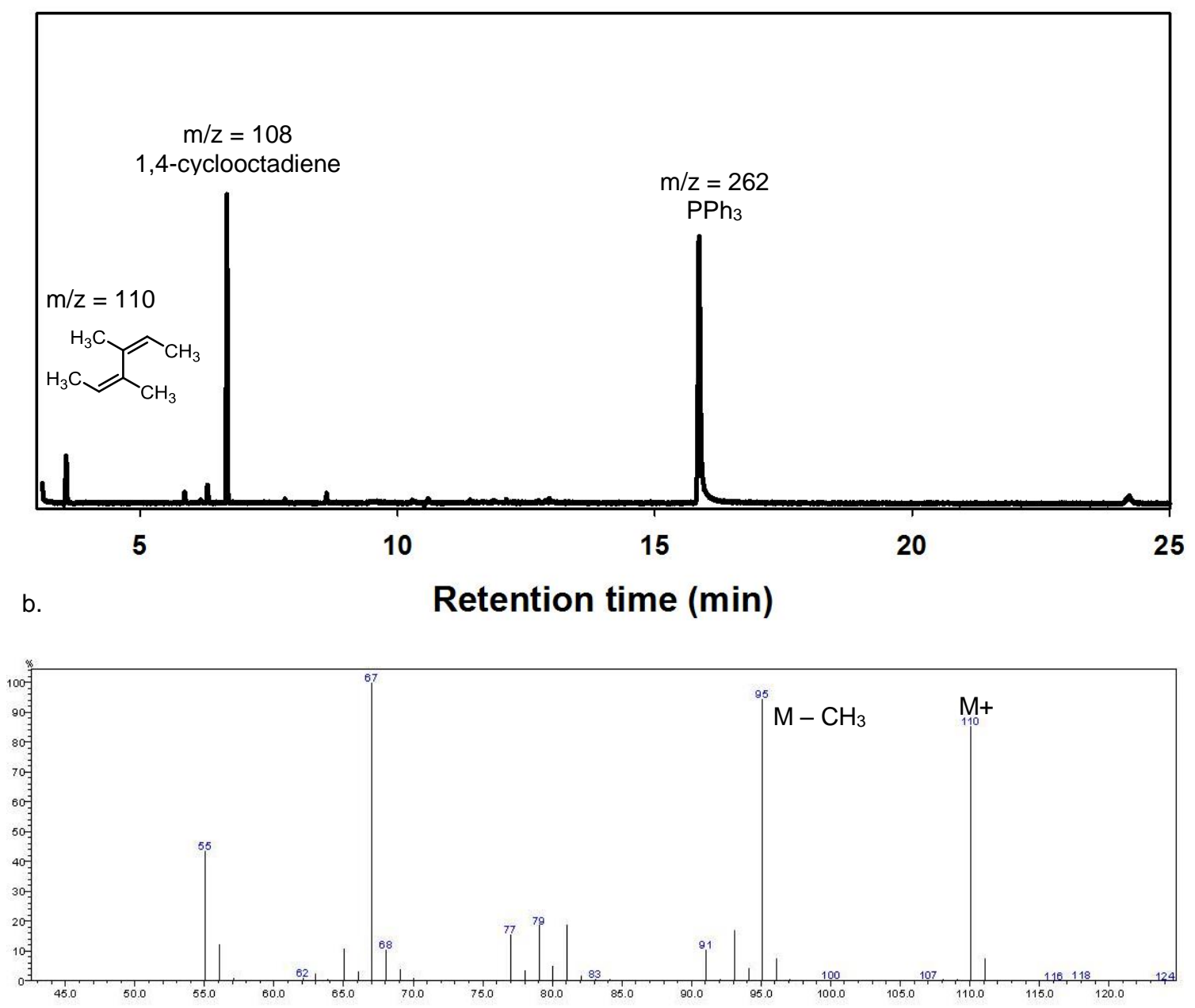

Figure S2. Gas chromatogram (a) for the attempted synthesis of S8 and mass spectrum (b) for peak at $3.4 \mathrm{~min}$ 


\section{NMR Spectra}
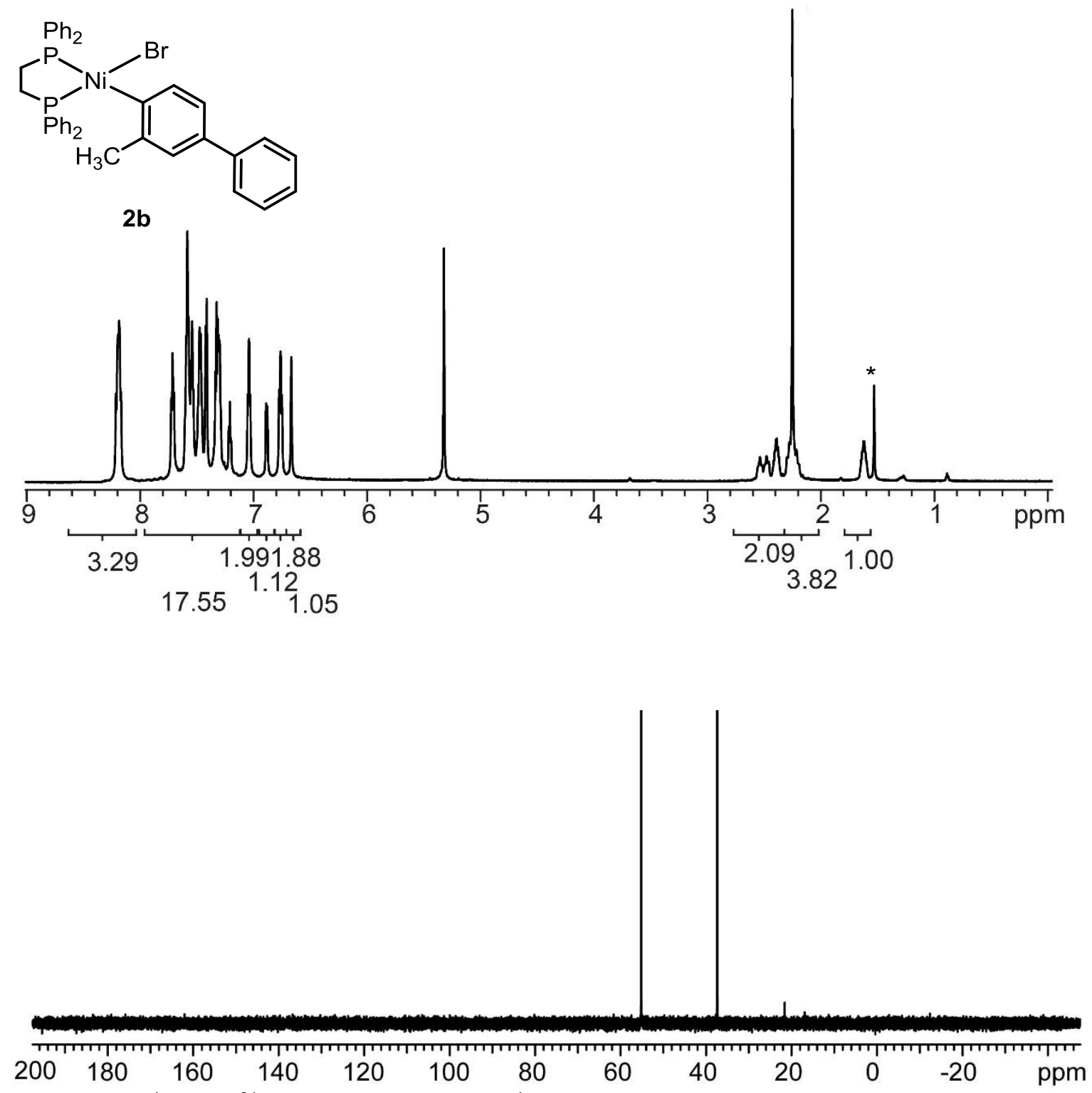

Figure S3. ${ }^{1} \mathrm{H}$ and ${ }^{31} \mathrm{P}$ NMR spectra of $2 \mathbf{b}{ }^{1} \mathrm{H}$ NMR $\left(700 \mathrm{MHz}, \mathrm{CD}_{2} \mathrm{Cl}_{2}\right) \delta 8.21-8.17(\mathrm{~m}, 4 \mathrm{H}), 7.71-$ $7.21(\mathrm{~m}, 18 \mathrm{H}), 7.04($ at, $J=6.3 \mathrm{~Hz}, 2 \mathrm{H}), 6.88(\mathrm{~d}, J=7.7 \mathrm{~Hz}, 1 \mathrm{H}), 6.76($ at, $J=9.8 \mathrm{~Hz}, 2 \mathrm{H}), 6.68$ (s, 1H), 2.51 (dt, $J=40.6,13.3 \mathrm{~Hz}, 1 \mathrm{H}), 2.41-2.37(\mathrm{~m}, 1 \mathrm{H}), 2.28-2.22(\mathrm{~m}, 1 \mathrm{H}), 2.25(\mathrm{~s}, 3 \mathrm{H}), 1.63-$ $1.62(\mathrm{~m}, 1 \mathrm{H})$. ${ }^{*}$ denotes residual $\mathrm{H}_{2} \mathrm{O}$

${ }^{31} \mathrm{P}$ NMR (283 MHz, $\left.\mathrm{CD}_{2} \mathrm{Cl}_{2}\right) \delta 55.16(\mathrm{~d}, J=19.0 \mathrm{~Hz}), 37.4(\mathrm{~d}, J=20.1 \mathrm{~Hz})$. 
<smiles>Cc1ccsc1N(P(Cl)c1ccccc1)[Pb](P)(Cl)c1ccccc1</smiles>
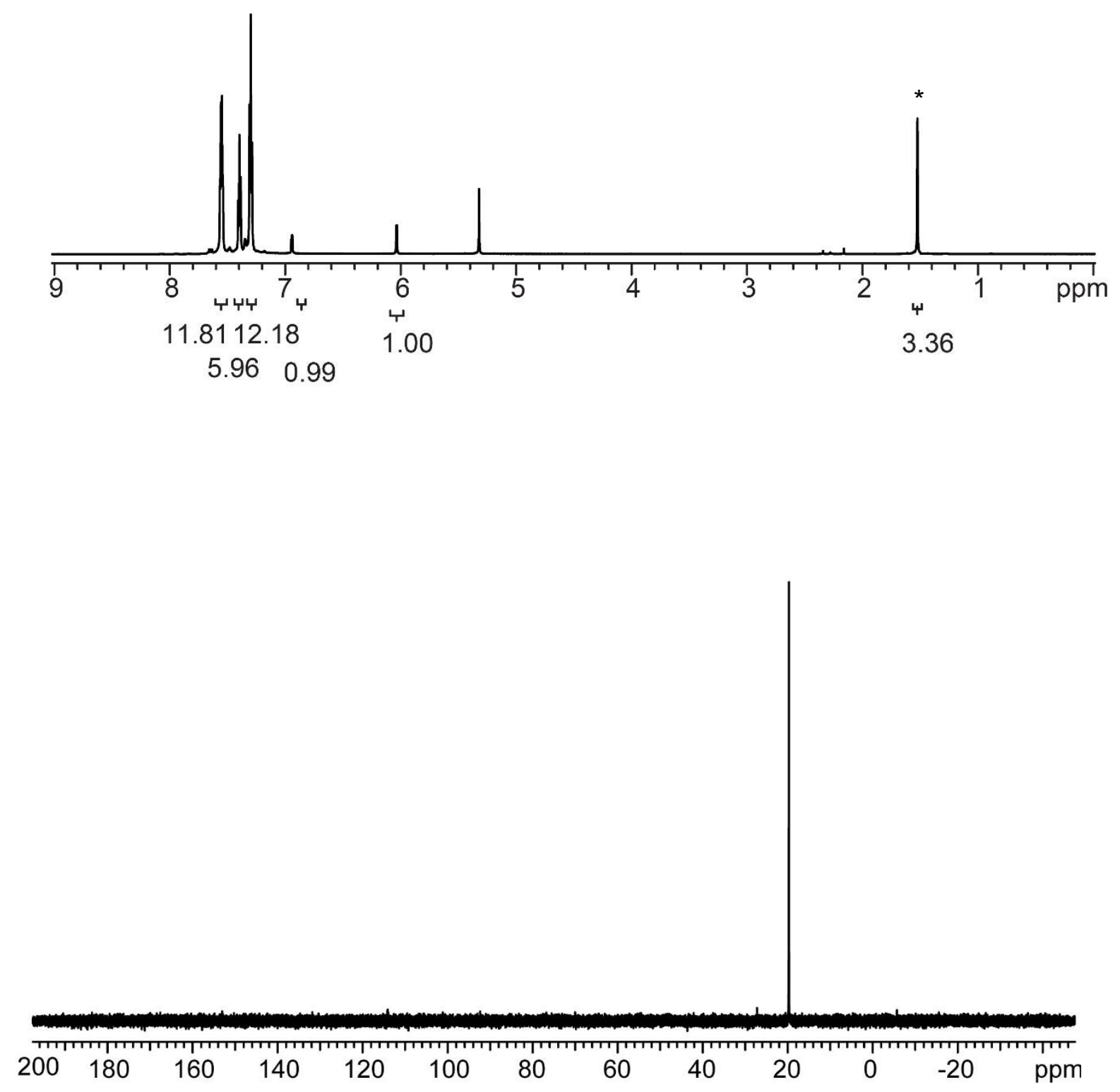

Figure S4. ${ }^{1} \mathrm{H}$ and ${ }^{31} \mathrm{P}$ NMR spectra of S1. ${ }^{1} \mathrm{H} \mathrm{NMR}\left(700 \mathrm{MHz}, \mathrm{CD}_{2} \mathrm{Cl}_{2}\right) \delta 7.55(\mathrm{dd}, \mathrm{J}=6.6 \mathrm{~Hz}$, $5.5 \mathrm{~Hz}, 12 \mathrm{H}$ ), 7.40 (t, $J=7.4 \mathrm{~Hz}, 6 \mathrm{H}$ ), 7.30 (at, $J=7.4 \mathrm{~Hz}, 12 \mathrm{H}), 6.94(\mathrm{~d}, J=4.2 \mathrm{~Hz}, 1 \mathrm{H}), 6.04$ $(\mathrm{d}, J=4.2 \mathrm{~Hz}, 1 \mathrm{H}), 1.52(\mathrm{~s}, 3 \mathrm{H})$. *denotes residual $\mathrm{H}_{2} \mathrm{O}$ ${ }^{31} \mathrm{P}$ NMR (283 MHz, $\left.\mathrm{CD}_{2} \mathrm{Cl}_{2}\right) \delta 19.69$. 
<smiles>Cc1ccsc1N(Cl)P1CCP(c2ccccc2)C1</smiles>
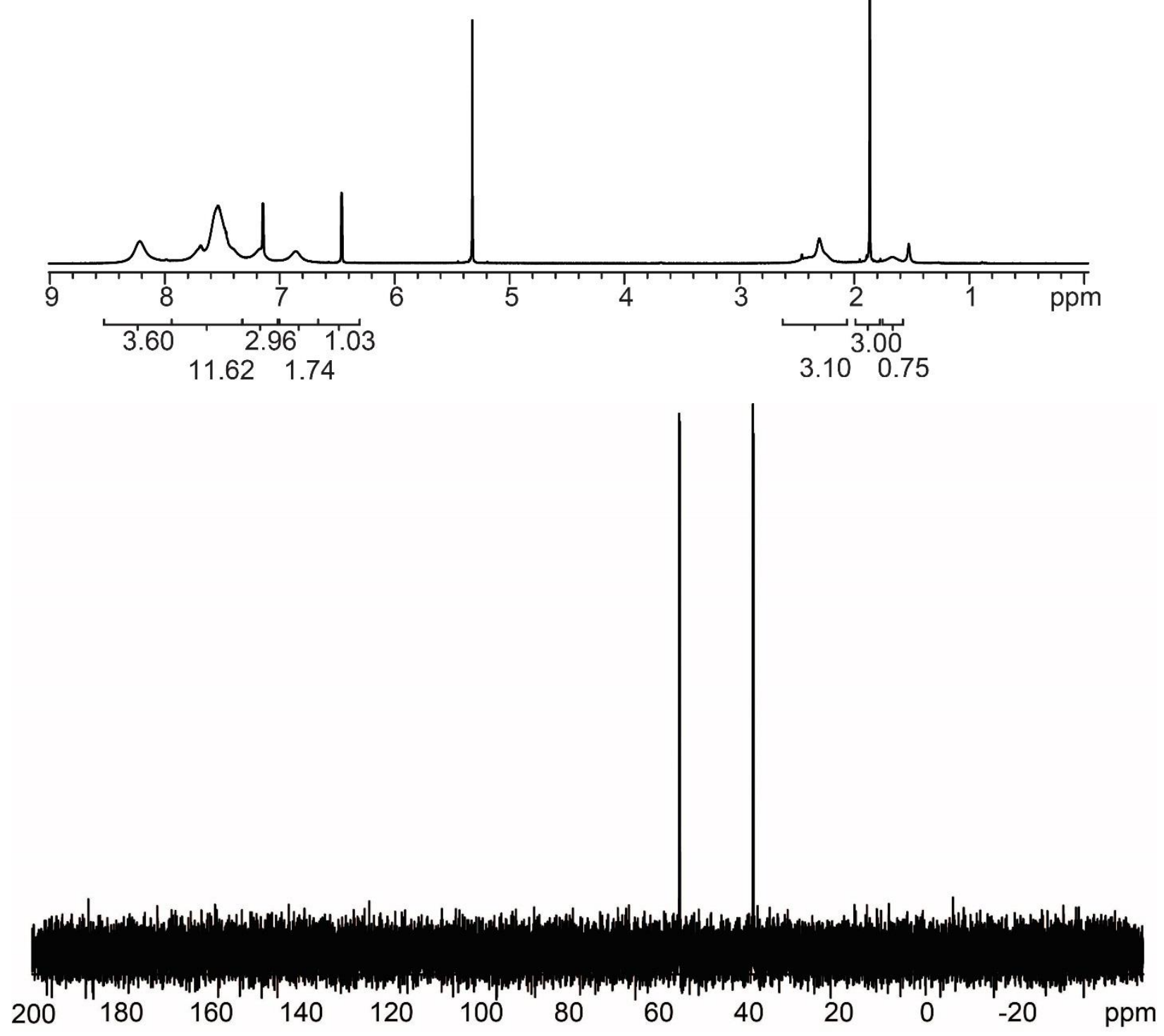

Figure S5. ${ }^{1} \mathrm{H}$ and ${ }^{31} \mathrm{P}$ NMR spectra of 2c. ${ }^{1} \mathrm{H}$ NMR (500 MHz, $\left.\mathrm{C}_{6} \mathrm{D}_{6}\right) \delta 8.05(\mathrm{bs}, 4 \mathrm{H}), 7.69-7.47$ $(\mathrm{m}, 12 \mathrm{H}), 7.15-7.14(\mathrm{~m}, 3 \mathrm{H}), 7.20-6.96(\mathrm{~m}, 3 \mathrm{H}), 6.89(\mathrm{bs}, 2 \mathrm{H}), 6.46(\mathrm{~s}, 1 \mathrm{H}), 3.60-3.56(\mathrm{~m}, 1 \mathrm{H})$, 2.33 (s, 3H), 1.73 (bs, 2H), 1.44-1.41 (m, 1H).

${ }^{31} \mathrm{P}$ NMR (202 MHz, $\left.\mathrm{C}_{6} \mathrm{D}_{6}\right) \delta 54.59(\mathrm{~d}, J=33.5 \mathrm{~Hz}), 38.20(\mathrm{~d}, J=33.5 \mathrm{~Hz})$. This compound is unstable and prone to decomposition. 


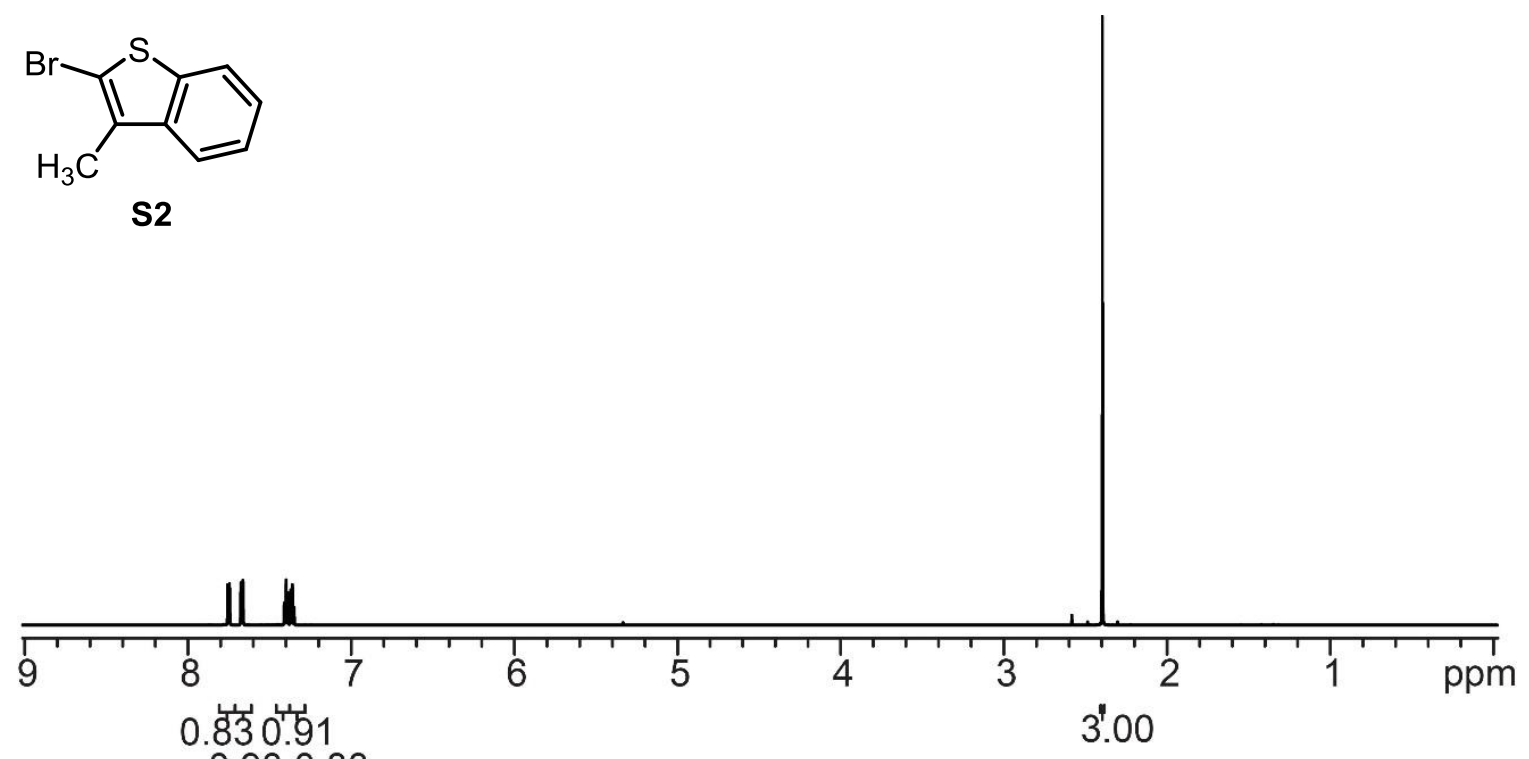

0.900 .88

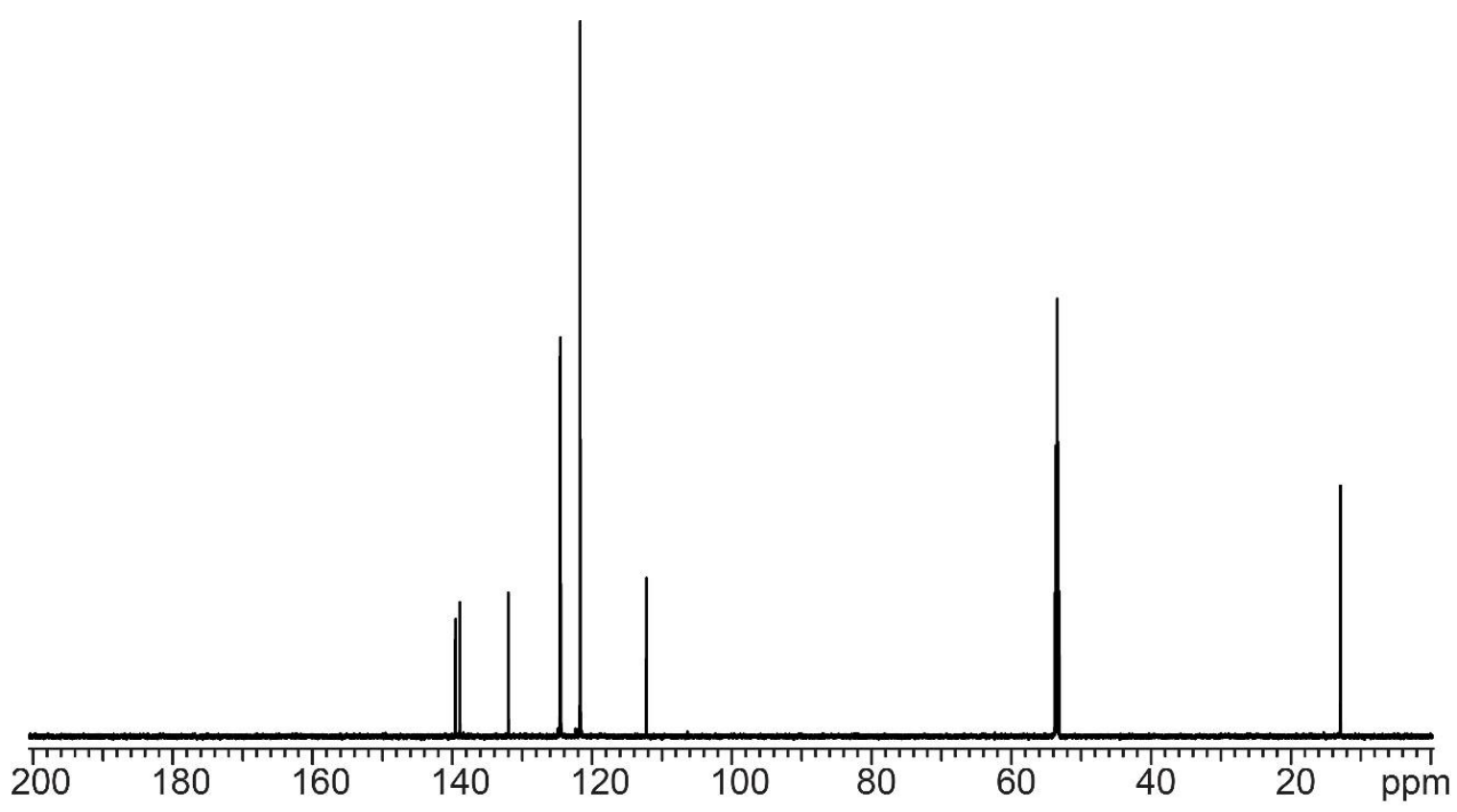

Figure S6. ${ }^{1} \mathrm{H}$ and ${ }^{13} \mathrm{C}$ NMR spectra of S2. ${ }^{1} \mathrm{H}$ NMR $\left(700 \mathrm{MHz}, \mathrm{CD}_{2} \mathrm{Cl}_{2}\right) \delta 7.75(\mathrm{dd}, J=7.5 \mathrm{~Hz}$, $0.85 \mathrm{~Hz}, 1 \mathrm{H}$ ), 7.66 (dd, $J=7.5 \mathrm{~Hz}, 0.51 \mathrm{~Hz}, 1 \mathrm{H}$ ), 7.39 (at, $J=7.7 \mathrm{~Hz}, 1 \mathrm{H}), 7.36$ (at, $J=7.7 \mathrm{~Hz}$, $1 \mathrm{H}), 2.40(\mathrm{~s}, 3 \mathrm{H})$.

${ }^{13} \mathrm{C}$ NMR $\left(176 \mathrm{MHz}, \mathrm{CD}_{2} \mathrm{Cl}_{2}\right) \delta 139.53,138.89,131.97,124.57,124.49,121.68$ (2 C), 112.20, 12.86 . 

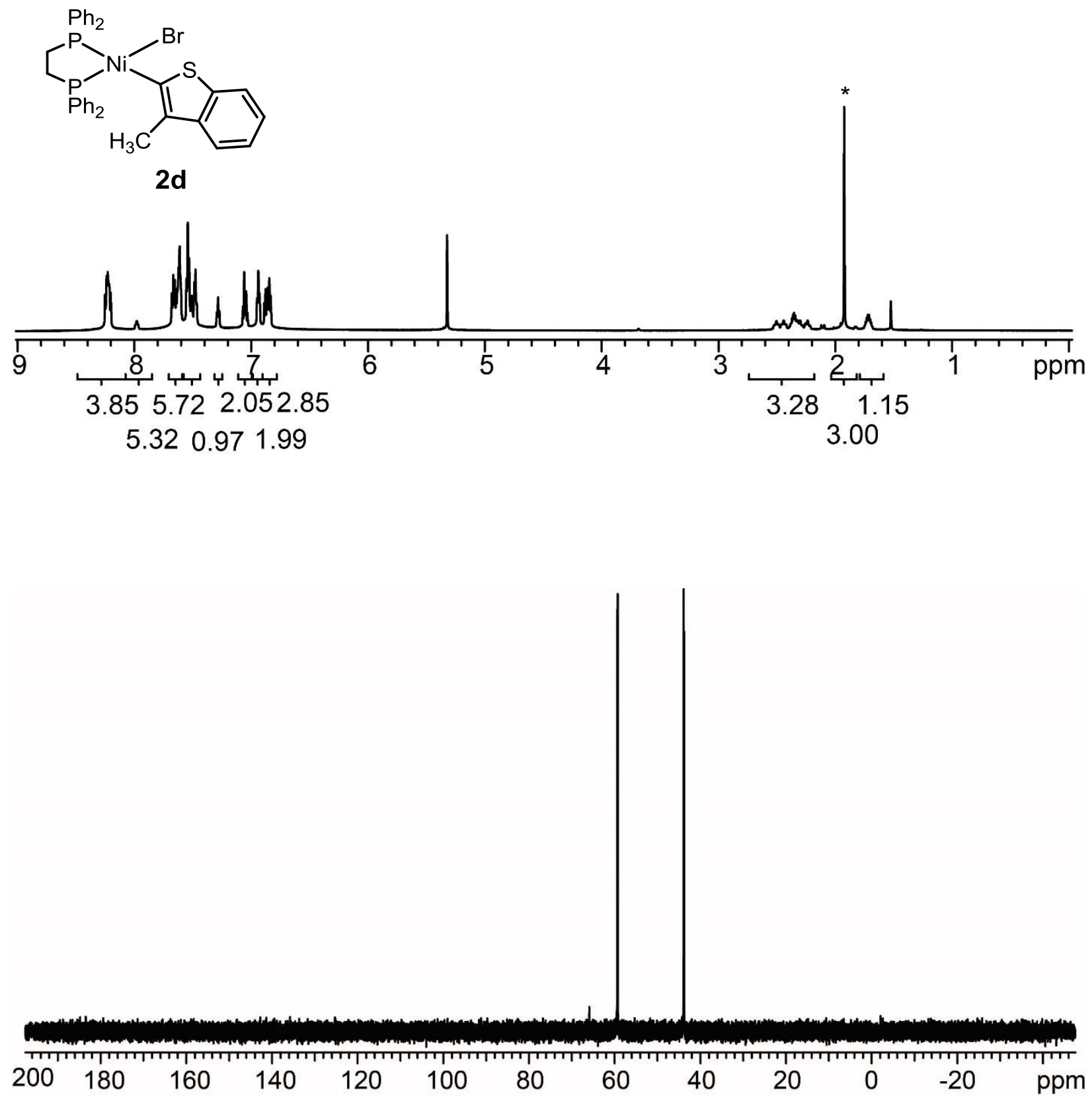

Figure S7. ${ }^{1} \mathrm{H}$ and ${ }^{31} \mathrm{P}$ NMR spectra of $2 \mathrm{~d} .{ }^{1} \mathrm{H}$ NMR $\left(700 \mathrm{MHz}, \mathrm{CD}_{2} \mathrm{Cl}_{2}\right) \delta 8.25-8.20(\mathrm{~m}, 4 \mathrm{H}), 7.68-$ $7.61(\mathrm{~m}, 5 \mathrm{H}), 7.55-7.46(\mathrm{~m}, 6 \mathrm{H}), 7.28($ at, $J=7.3 \mathrm{~Hz}, 1 \mathrm{H}), 7.07-7.03(\mathrm{~m}, 2 \mathrm{H}), 6.94$ (at, $J=7.7$ $\mathrm{Hz}, 2 \mathrm{H}), 6.89-6.83(\mathrm{~m}, 3 \mathrm{H}), 2.47(\mathrm{td}, J=42.7,11.2 \mathrm{~Hz}, 1 \mathrm{H}), 2.38-2.22(\mathrm{~m}, 2 \mathrm{H}), 1.92(\mathrm{~s}, 3 \mathrm{H})$, 1.74-1.69 $(\mathrm{m}, 1 \mathrm{H})$. *denotes residual $\mathrm{H}_{2} \mathrm{O}$

${ }^{31} \mathrm{P}$ NMR (283 MHz, $\left.\mathrm{CD}_{2} \mathrm{Cl}_{2}\right) \delta 59.32(\mathrm{~d}, J=35.9 \mathrm{~Hz}), 43.82(\mathrm{~d}, J=35.9 \mathrm{~Hz})$. 

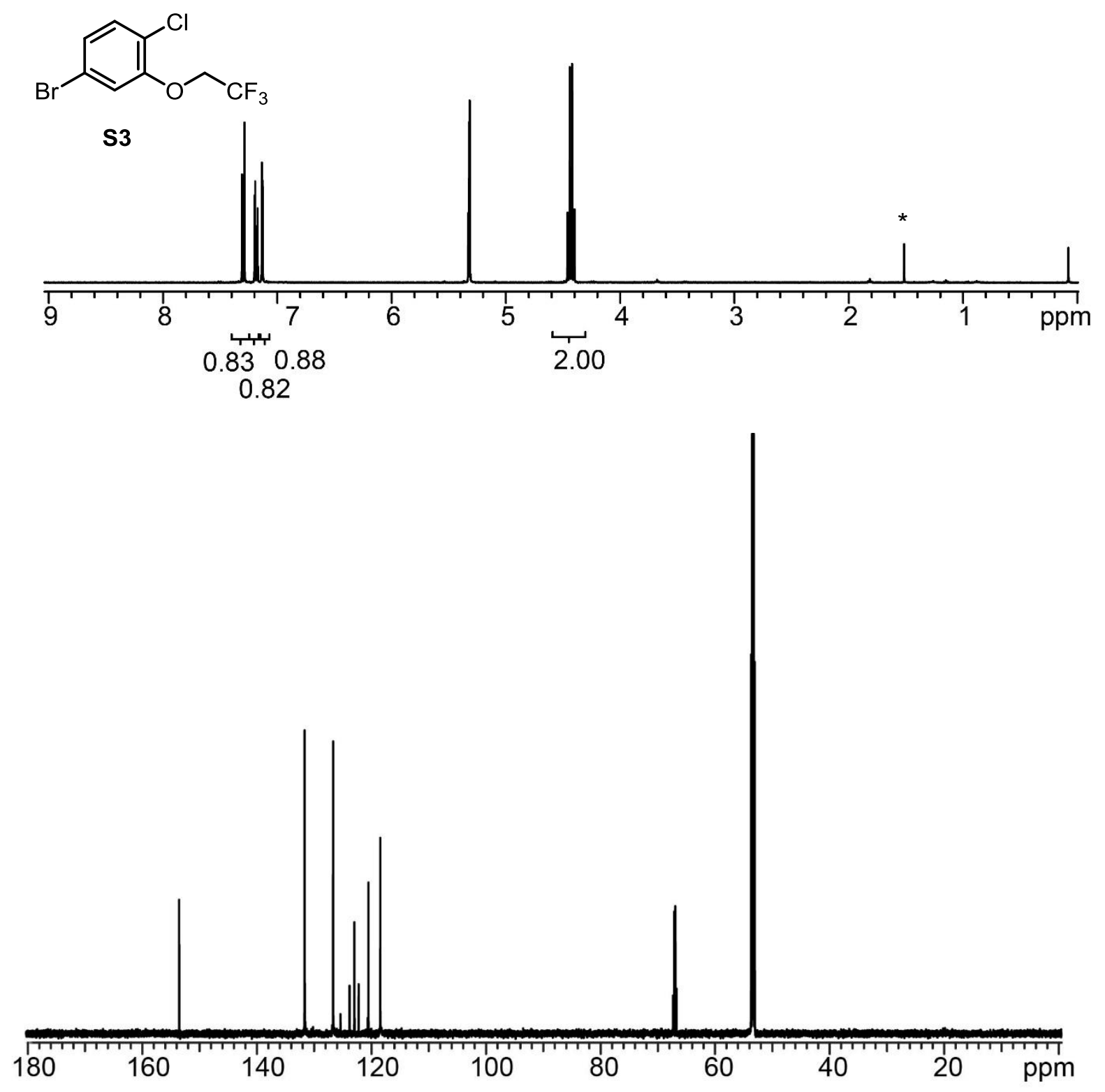

Figure S8. ${ }^{1} \mathrm{H}$ and ${ }^{13} \mathrm{C}$ NMR spectra of S3. ${ }^{1} \mathrm{H}$ NMR $\left(400 \mathrm{MHz}, \mathrm{CD}_{2} \mathrm{Cl}_{2}\right) \delta 7.30(\mathrm{~d}, J=8.4 \mathrm{~Hz}, 1 \mathrm{H})$, $7.19(\mathrm{dd}, J=8.4 \mathrm{~Hz}, 2.1 \mathrm{~Hz}, 1 \mathrm{H}), 7.13(\mathrm{~d}, J=2.1 \mathrm{~Hz}, 1 \mathrm{H}), 4.43\left(\mathrm{q}, J_{H-F}=8.0 \mathrm{~Hz}\right){ }^{*}$ denotes residual $\mathrm{H}_{2} \mathrm{O}$

${ }^{31} \mathrm{C}$ NMR $\left(176 \mathrm{MHz}, \mathrm{CD}_{2} \mathrm{Cl}_{2}\right) \delta 153.56,131.66,126.87,123.02$ (q, $\left.J_{C-F}=278.6 \mathrm{~Hz}\right), 122.97$, 120.51, 118.45, 67.04 (q, $\left.J_{C-F}=72.3 \mathrm{~Hz}\right)$ 

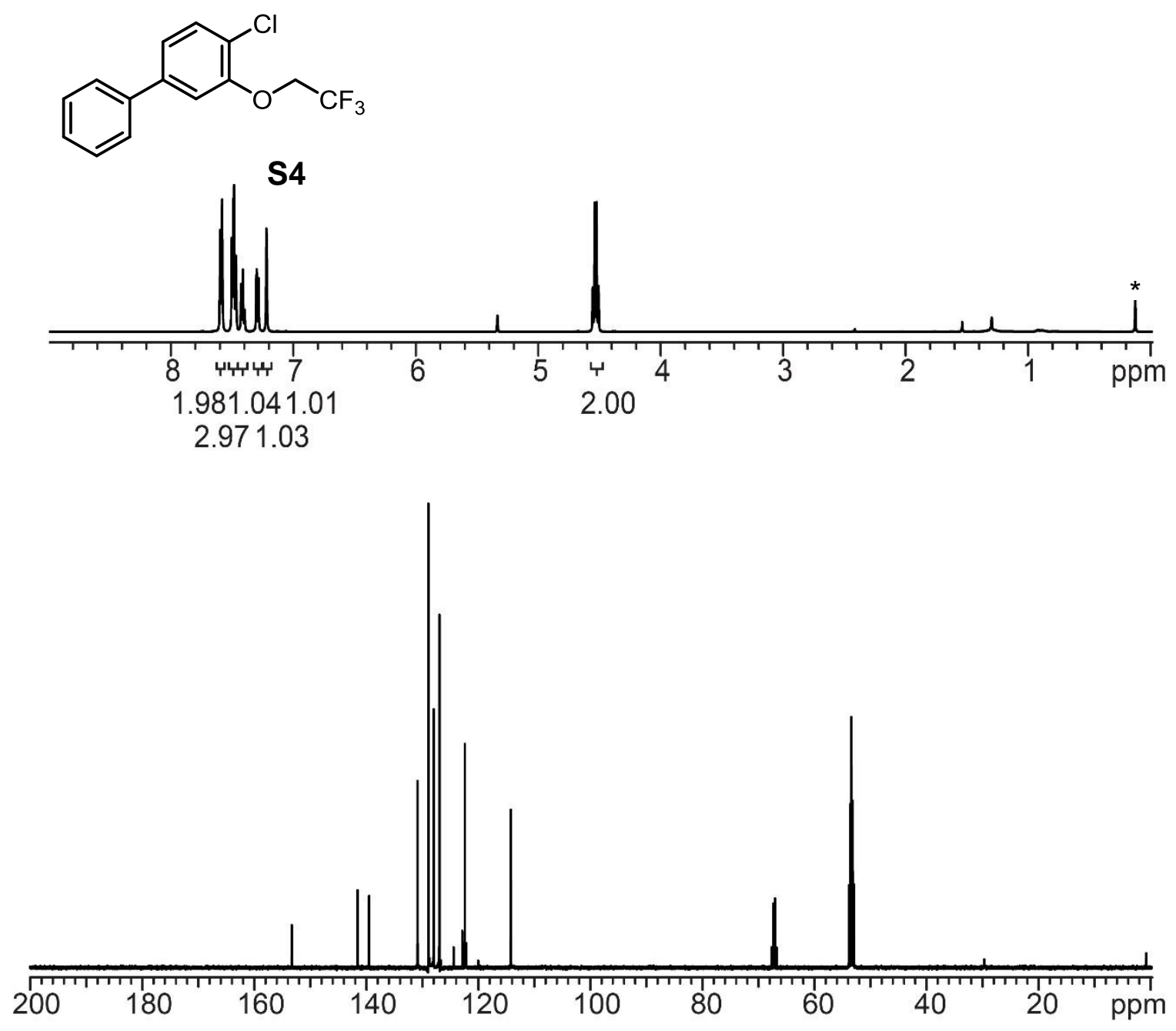

Figure S9. ${ }^{1} \mathrm{H}$ and ${ }^{13} \mathrm{C}$ NMR spectra of $\mathbf{S} 4 .{ }^{1} \mathrm{H}$ NMR $\left(700 \mathrm{MHz}, \mathrm{CD}_{2} \mathrm{Cl}_{2}\right) \delta 7.59(\mathrm{~d}, J=7.8 \mathrm{~Hz}, 2 \mathrm{H})$, $7.50-7.47(\mathrm{~m}, 3 \mathrm{H}), 7.41(\mathrm{t}, J=7.3 \mathrm{~Hz}, 1 \mathrm{H}), 7.28(\mathrm{dd}, J=8.2 \mathrm{~Hz}, 1.7 \mathrm{~Hz}, 1 \mathrm{H}) 7.20(\mathrm{~d}, J=1.5 \mathrm{~Hz}$, $1 \mathrm{H}), 4.53\left(\mathrm{q}, \mathrm{J}_{\mathrm{H}-\mathrm{F}}=8.2 \mathrm{~Hz}, 2 \mathrm{H}\right)$, *denotes residual grease.

${ }^{13} \mathrm{C}$ NMR $\left(176 \mathrm{MHz}, \mathrm{CD}_{2} \mathrm{Cl}_{2}\right) \delta$ 153.31, 141.56, 139.49, 130.84, 128.92, 127.98, 123.31 (q, JC-F= $278.2 \mathrm{~Hz}), 122.89,122.42,114.19,67.18\left(\mathrm{q}, J_{C-F}=36.2 \mathrm{~Hz}\right)$. 

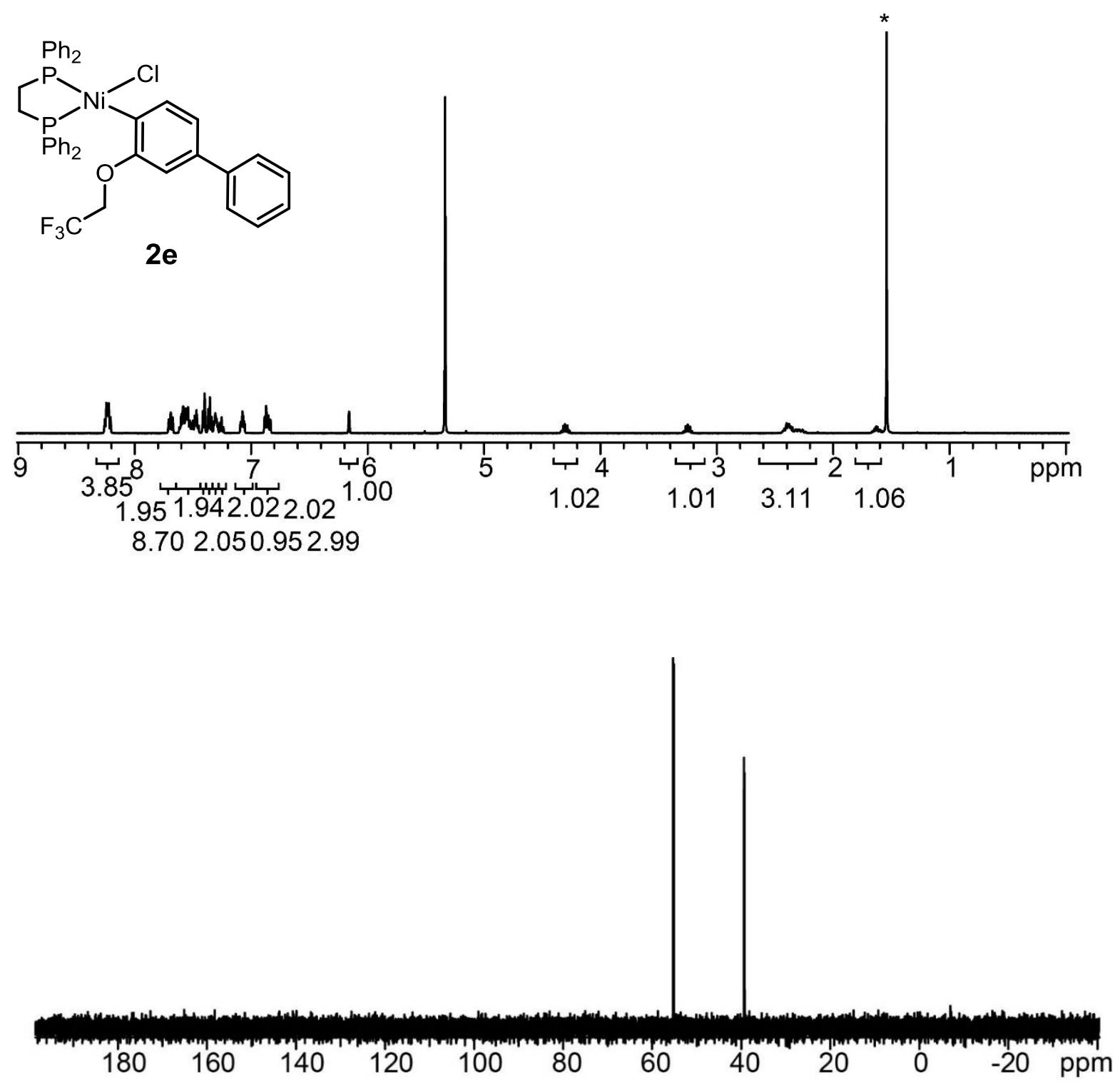

Figure S10. ${ }^{1} \mathrm{H}$ and ${ }^{31} \mathrm{P}$ NMR spectra of $2 \mathrm{e} .{ }^{1} \mathrm{H}$ NMR $\left(500 \mathrm{MHz}, \mathrm{CD}_{2} \mathrm{Cl}_{2}\right) \delta 8.23(\mathrm{~m}, 4 \mathrm{H}) 7.69$ (dd, $J=9.8,1.7 \mathrm{~Hz}, 2 \mathrm{H}), 7.60-7.47(\mathrm{~m}, 9 \mathrm{H}), 7.41(\mathrm{~d}, J=7.5 \mathrm{~Hz}, 2 \mathrm{H}), 7.35($ at, $J=7.5 \mathrm{~Hz}, 2 \mathrm{H}), 7.32-$ $7.29(\mathrm{~m}, 2 \mathrm{H}), 7.27-7.24(\mathrm{~m}, 2 \mathrm{H}), 7.09-7.06(\mathrm{~m}, 2 \mathrm{H}), 6.88-6.83(\mathrm{~m}, 3 \mathrm{H}), 6.16(\mathrm{~s}, 1 \mathrm{H}), 4-34-4.26$ $(\mathrm{m}, 1 \mathrm{H}), 3.28-3.21(\mathrm{~m}, 1 \mathrm{H}) 2.43-2.24(\mathrm{~m}, 3 \mathrm{H}), 1.66-1.59(\mathrm{~m}, 1 \mathrm{H}) .{ }^{*}$ denotes residual $\mathrm{H}_{2} \mathrm{O}$ ${ }^{31} \mathrm{P}$ NMR (202 MHz, $\mathrm{CD}_{2} \mathrm{Cl}_{2}$ ) $\delta 55.20$ (d, $J=30.3 \mathrm{~Hz}$ ), 39.31 (d, $J=28.9 \mathrm{~Hz}$ ). 

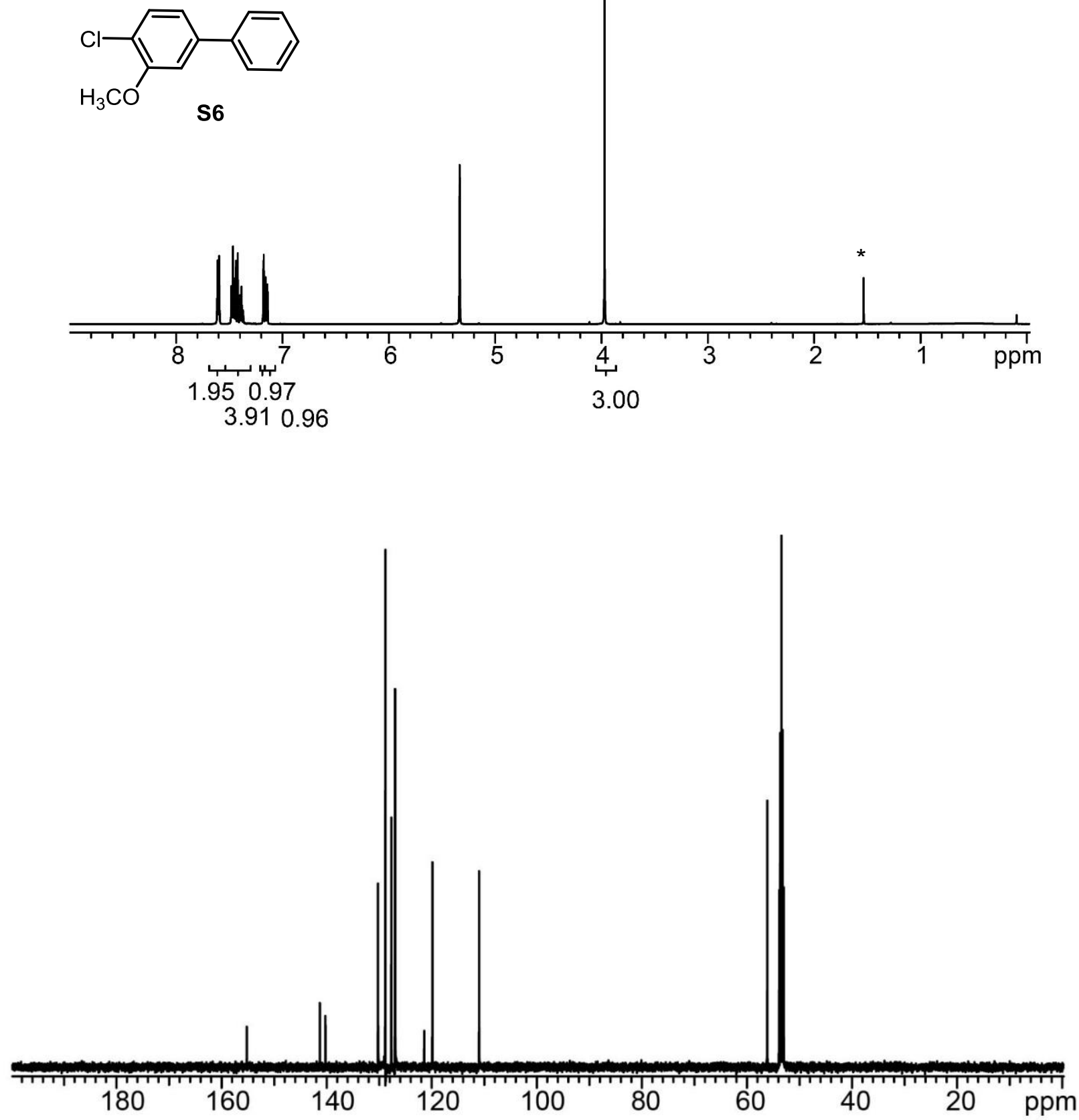

Figure S11. ${ }^{1} \mathrm{H}$ and ${ }^{13} \mathrm{C}$ NMR spectra of $\mathbf{S 6}{ }^{1} \mathrm{H}$ NMR $\left(500 \mathrm{MHz}, \mathrm{CD}_{2} \mathrm{Cl}_{2}\right) \delta 7.61-7.59(\mathrm{~m}, 2 \mathrm{H})$, 7.48-7.37 (m, 4H), 7.18 (d, $J=2.0 \mathrm{~Hz}, 2 \mathrm{H}), 7.15$ (dd, $J=8.1 \mathrm{~Hz}, 2.0 \mathrm{~Hz}, 1 \mathrm{H}) 3.97$ (s, 3H), "denotes residual $\mathrm{H}_{2} \mathrm{O}$. ${ }^{*}$ denotes residual $\mathrm{H}_{2} \mathrm{O}$ ${ }^{13} \mathrm{C}$ NMR $\left(176 \mathrm{MHz}, \mathrm{CD}_{2} \mathrm{Cl}_{2}\right)$ 155.18, 141.28, 140.23, 130.23, 126.82, 128.79, 127.70, 126.97, $121.41,119.86,110.98,56.11$. 

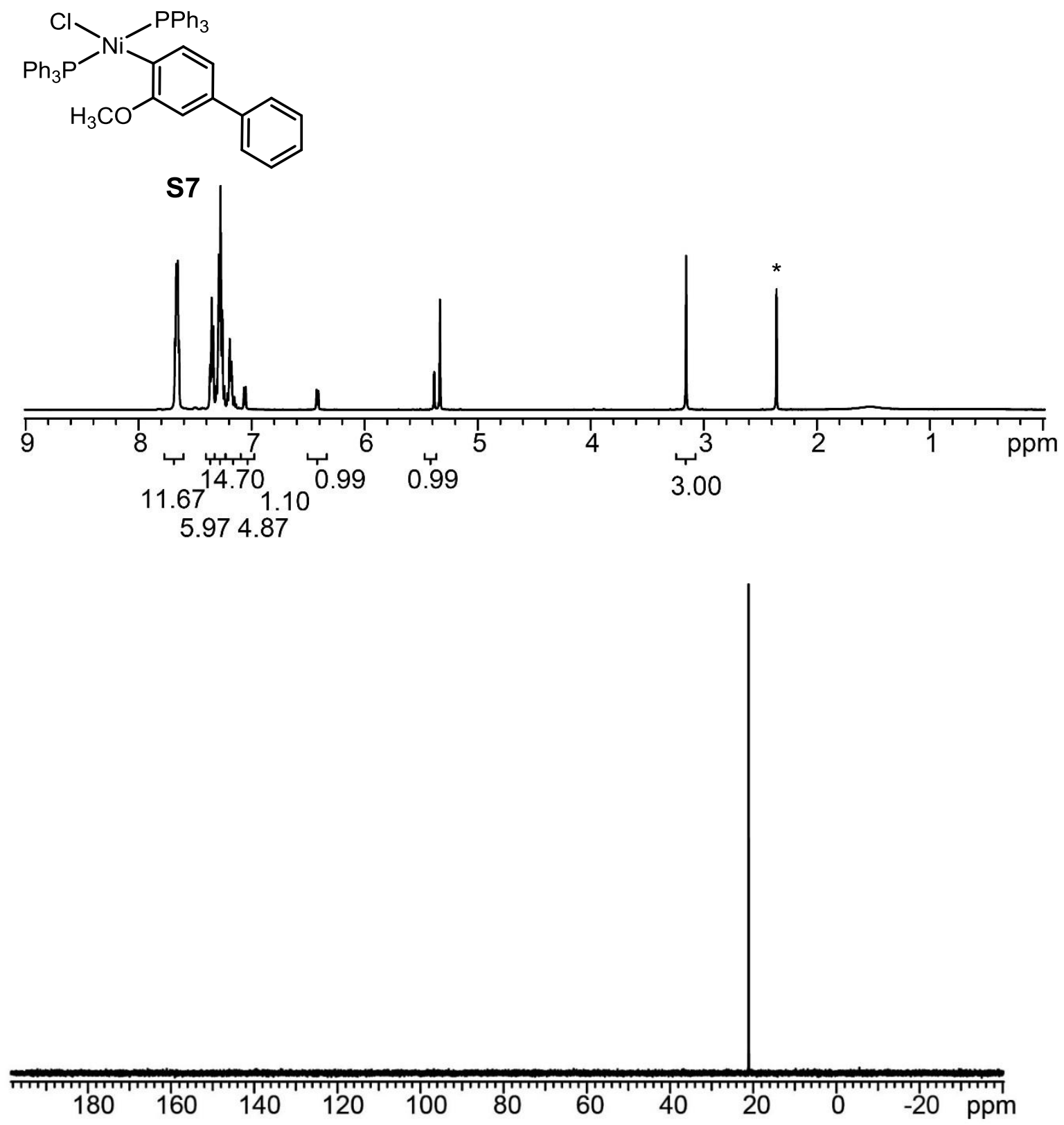

Figure S12. ${ }^{1} \mathrm{H}$ and ${ }^{31} \mathrm{P}$ NMR spectra of $\mathbf{S 7} .{ }^{1} \mathrm{H}$ NMR $\left(500 \mathrm{MHz}, \mathrm{CD}_{2} \mathrm{Cl}_{2}\right) \delta 7.66(\mathrm{dd}, \mathrm{J}=12.0,5.1$, $12 \mathrm{H}) 7.35$ (at, $J=7.2,6 \mathrm{H}) 7.31-7.24(\mathrm{~m}, 15 \mathrm{H}), 7.21-7.15(\mathrm{~m}, 5 \mathrm{H}), 7.06(\mathrm{~d}, J=7.5 \mathrm{~Hz}, 1 \mathrm{H}), 6.41$ $(\mathrm{d}, J=7.5 \mathrm{~Hz}, 1 \mathrm{H}), 5.38(\mathrm{~s}, 1 \mathrm{H}), 3.12(\mathrm{~s}, 3 \mathrm{H}){ }^{*}$ denotes residual toluene ${ }^{31} \mathrm{P}$ NMR $\left(202 \mathrm{MHz}, \mathrm{CD}_{2} \mathrm{Cl}_{2}\right) \delta 21.08$. 

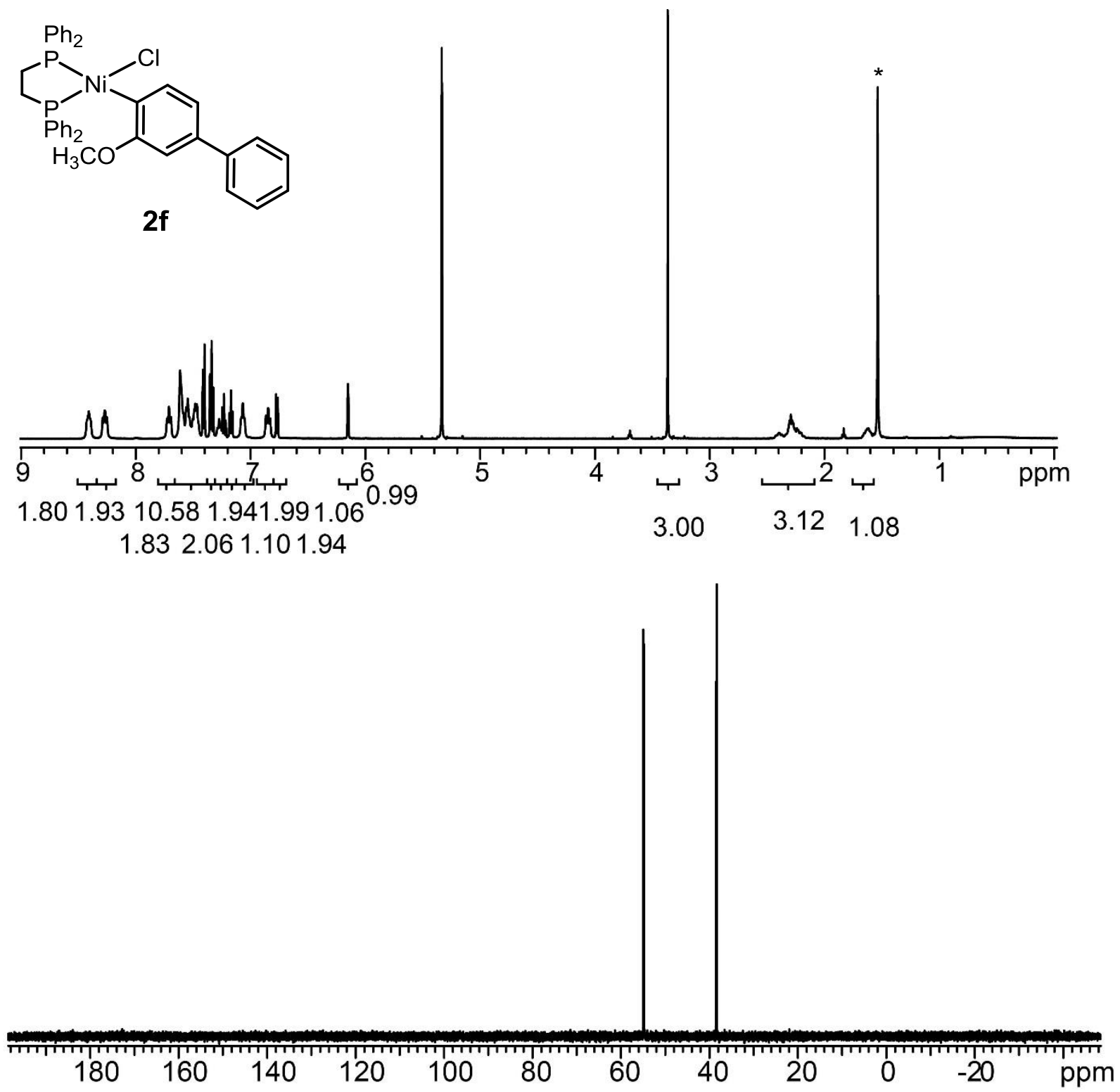

Figure S13. ${ }^{1} \mathrm{H}$ and ${ }^{31} \mathrm{P}$ NMR spectra of $2 \mathrm{2f} .{ }^{1} \mathrm{H}$ NMR $\left(500 \mathrm{MHz}, \mathrm{CD}_{2} \mathrm{Cl}_{2}\right) \delta 8.41(\mathrm{br}, 2 \mathrm{H}) 8.27$ (at, $J=9.0 \mathrm{~Hz}, 2 \mathrm{H}), 7.71$ (at, $J=8.5 \mathrm{~Hz}, 2 \mathrm{H}), 7.61-7.40(\mathrm{~m}, 11 \mathrm{H}), 7.34$ (at, $J=7.5 \mathrm{~Hz}, 2 \mathrm{H}), 7.27-$ $7.22(\mathrm{~m}, 2 \mathrm{H}), 7.17($ at, $J=7.0 \mathrm{~Hz}, 2 \mathrm{H}), 7.07$ (at, $J=6.6,2 \mathrm{H}) 6.85$ (at, $J=9.1 \mathrm{~Hz}, 2 \mathrm{H}$ ), 6.77 (dt, $J$ $=6.1 \mathrm{~Hz}, 1.5 \mathrm{~Hz}, 1 \mathrm{H}), 6.15(\mathrm{at}, J=2.1 \mathrm{~Hz}, 1 \mathrm{H}), 3.37(\mathrm{~s}, 3 \mathrm{H}), 2.39-2.21(\mathrm{~m}, 3 \mathrm{H}), 1.63-1.62(\mathrm{~m}$, $1 \mathrm{H})$. *denotes residual $\mathrm{H}_{2} \mathrm{O}$

${ }^{31} \mathrm{P}$ NMR (202 MHz, $\mathrm{CD}_{2} \mathrm{Cl}_{2}$ ) $\delta 59.85$ (d, $J=27.5 \mathrm{~Hz}$ ), 38.37 (d, $\left.J=27.5 \mathrm{~Hz}\right)$. 


\section{Initiation Rate Studies}

\section{Representative Procedure for Performing React IR Propagation Rate Studies:}

The IR probe was inserted through an O-ring sealed 14/20 ground glass adapter (custom-made) into an oven-dried $50 \mathrm{~mL}$ 2-neck flask equipped with a stir bar. The other neck was fitted with a three-way flow control adapter with a septum for injections/aliquot sampling and an $\mathrm{N}_{2}$ line. The oven-dried flask was cooled under vacuum. The flask was then filled with $\mathrm{N}_{2}$ and evacuated again for a total of three cycles. The flask was charged with a solution of precatalyst $2 \mathrm{f}(3.0 \mathrm{~mL}, 0.005 \mathrm{M}$ in THF, 1.00 equiv) and cooled to $0^{\circ} \mathrm{C}$ over $20 \mathrm{~min}$. After recording a background spectrum, monomer $(0.42 \mathrm{~mL}, 0.35 \mathrm{M}$ in THF, 10 equiv) was added by syringe and the reaction was stirred at $0{ }^{\circ} \mathrm{C}$ until monomer consumption stalled for $10 \mathrm{~min}$. Then, THF $(3.8 \mathrm{~mL})$ and a second portion of monomer solution ( $2.8 \mathrm{~mL}, 0.35 \mathrm{M}$ in THF, 65 equiv) were injected and spectra were recorded every $15 \mathrm{~s}$ over the entire reaction. To account for mixing and temperature equilibration, spectra recorded in the first $60 \mathrm{~s}$ of the reaction were not analyzed. The propagation rate constant $\left(\mathrm{k}_{\mathrm{p}}\right)$ was calculated by plotting [monomer] versus time over the first $10 \%$ conversion of monomer (the second addition). When $\mathrm{PPh}_{3}$ was included, 2 equiv relative to precatalyst was added in the precatalyst stock solution.

Table S1. Table of $k_{p}$ values

\begin{tabular}{cc}
\hline $\begin{array}{c}k_{p} \text { without } \mathrm{PPh}_{3} \\
\left(\mathrm{~s}^{-1} \times 10^{-3}\right)\end{array}$ & $\begin{array}{c}k_{p} \text { with } \mathrm{PPh}_{3} \\
\left(\mathrm{~s}^{-1} \times 10^{-3}\right)\end{array}$ \\
\hline 10.9 & 6.7 \\
8.9 & 8.4 \\
12.0 & 9.0 \\
11.4 & 6.7 \\
7.28 & 6.66 \\
Average $=10 \pm 2$ & Average $=7.5 \pm 1$ \\
\hline
\end{tabular}


Representative Procedure for Performing React IR Initiation Rate Studies:

The IR probe was inserted through an O-ring sealed 14/20 ground glass adapter (custom-made) into an oven-dried $50 \mathrm{~mL}$ 2-neck flask equipped with a stir bar. The other neck was fitted with a three-way flow control adapter with a septum for injections/aliquot sampling and an $\mathrm{N}_{2}$ line. The oven-dried flask was cooled under vacuum. The flask was then filled with $\mathrm{N}_{2}$ and evacuated again for a total of three cycles. The flask was charged with THF $(6.7 \mathrm{~mL})$ and cooled to $0{ }^{\circ} \mathrm{C}$ for $15 \mathrm{~min}$. After recording a background spectrum, monomer (2.3 mL, 0.44M in THF, 1.0 equiv) was added by syringe and allowed to equilibrate at $0{ }^{\circ} \mathrm{C}$ for at least 5 min before proceeding. The catalyst solution ( $1.0 \mathrm{~mL}, 0.015 \mathrm{M}, 0.015$ equiv) was then injected and spectra were recorded every $15 \mathrm{~s}$ over the entire reaction. To account for mixing and temperature equilibration, spectra recorded in the first $60 \mathrm{~s}$ of the reaction were not analyzed.

\section{Representative Procedure for $k_{o b s}$ Calculation:}

The absorbance was converted to concentration using the appropriate calibration curves. The initial rate was obtained from $10 \%$ conversion and converted to the observed rate constant $\left(k_{o b s}\right)$ using equation $\mathrm{S} 1$ :

initial rate $=-\frac{d[\text { monomer }]}{d t}=k_{o b s}[N i]_{\text {total }}$

\section{Derivation and Representative Procedure for $k_{i}$ Calculation:}

The observed rate constant $\left(k_{o b s}\right)$ is a weighted average of rate constant of initiation $\left(k_{i}\right)$ and propagation $\left(k_{p}\right)$ during the beginning of polymerization.

$$
k_{\text {obs }}=k_{i} \frac{[\mathrm{Ni}]_{i}}{[\mathrm{Ni}]_{\text {total }}}+k_{p} \frac{[\mathrm{Ni}]_{p}}{[\mathrm{Ni}]_{\text {total }}}
$$

The concentration of nickel precatalyst undergoing initiation $\left([\mathrm{Ni}]_{\mathrm{i}}\right)$ is determined by an exponential decay dependent on $\mathrm{k}_{\mathrm{i}}$, time, and the initial concentration of nickel ([Ni] $\left.]_{(0)}\right)$ :

$$
[N i]_{i}=[N i]_{i(0)} e^{-k_{i} t}
$$

Assuming that all precatalyst undergoes initiation, $[\mathrm{Ni}]_{i(0)}=[\mathrm{Ni}]_{\text {total }}$, so we rearranged the exponential decay as follows:

$$
\frac{[N i]_{i}}{[N i]_{\text {total }}}=e^{-k_{i} t}
$$

We assume all nickel species in solution are undergoing initiation or propagation; therefore, 
$[N i]_{\text {total }}=[N i]_{i}+[N i]_{p}$

By dividing each side by $[\mathrm{Ni}]_{\text {total, }}$, we reach

$\frac{[N i]_{\text {total }}}{[N i]_{\text {total }}}=\frac{[N i]_{i}}{[N i]_{\text {total }}}+\frac{[N i]_{p}}{[N i]_{\text {total }}}$

and by rearranging and plugging in the exponential decay equation, we derive:

$\frac{[N i]_{p}}{[N i]_{\text {total }}}=1-\frac{[N i]_{i}}{[N i]_{\text {total }}}=1-e^{-k_{i} t}$

By substituting the new definitions for $\mathrm{k}_{\mathrm{i}}$ and $\mathrm{k}_{\mathrm{p}}$ into the equation defining $\mathrm{k}_{\mathrm{obs}}$, we arrive at equation 2:

$k_{o b s}=k_{i}\left(e^{-k_{i} t}\right)+k_{p}\left(1-e^{-k_{i} t}\right)$

The solve function of Mathematica was utilized to calculate $k_{i}$ for each catalyst, using reaction time for $10 \%$ monomer conversion, and $k_{\text {obs }}$ obtained from the initiation study. The propagation rate constant $\left(k_{p}\right)$ was measured experimentally as described in the previous section. 

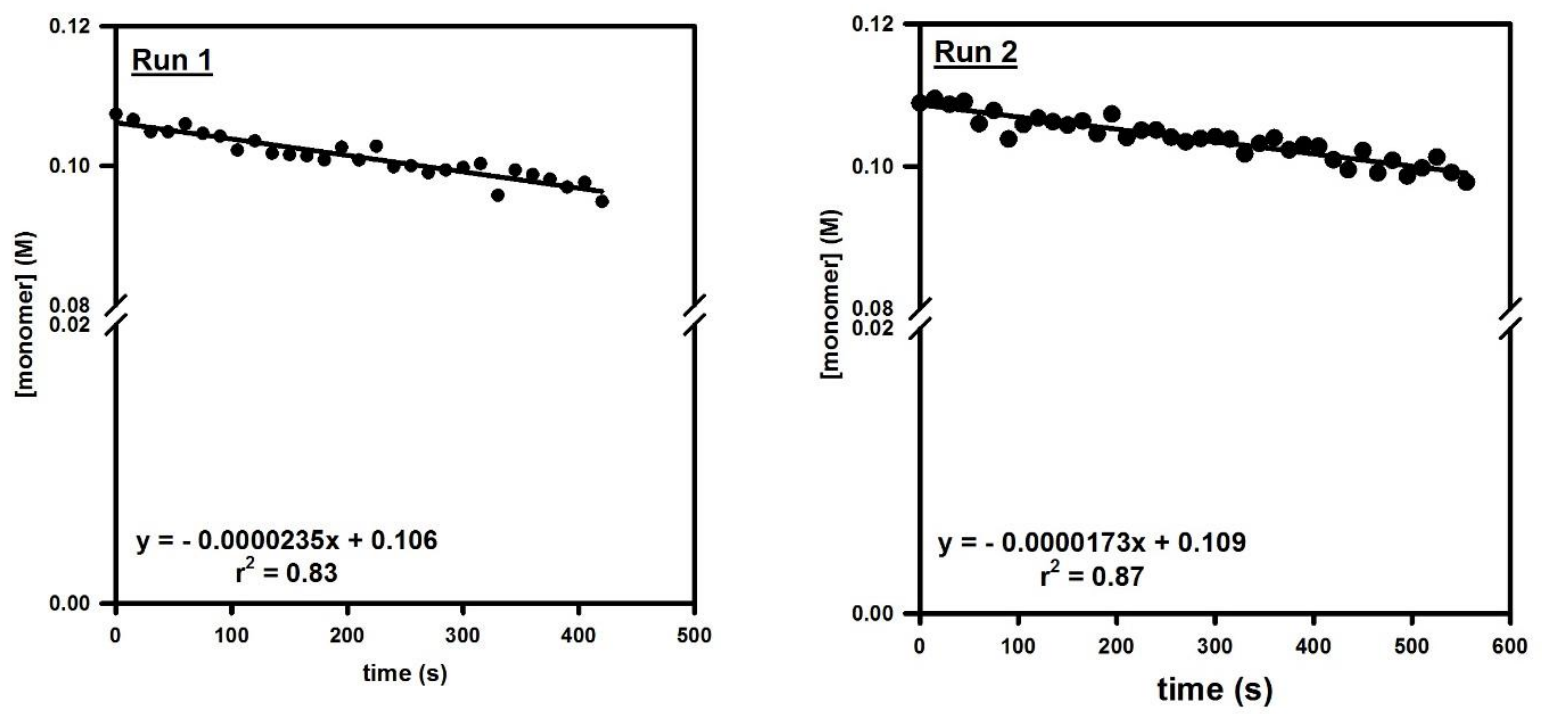

Figure S14. Plot of [monomer] versus for the polymerization of monomer $\mathbf{1}$ catalyzed by $\mathbf{2 b}$. $\left(\right.$ temp $=0{ }^{\circ} \mathrm{C},[2 \mathrm{~b}]=0.0015 \mathrm{M},[$ monomer $]=0.11 \mathrm{M}($ Run 1), $0.11 \mathrm{M}$ (Run 2)). The initiation rate constant $k_{i}$ was not calculated for run 1 because equation 1 fails when $k_{\text {obs }}>k_{p}$.

Table S2. Table of data for the plots in Figure S14.

\begin{tabular}{ccccc}
\hline Run & $\begin{array}{c}\text { Initial rate } \\
\left(10^{-6} \times \mathrm{M} \mathrm{s}^{-1}\right)\end{array}$ & $\begin{array}{c}k_{\text {obs }} \\
\left(10^{-3} \mathrm{x} \mathrm{s}^{-1}\right)\end{array}$ & $\begin{array}{c}\text { Time at 10\% conversion } \\
(\mathrm{s})\end{array}$ & $\begin{array}{c}\text { Calculated } k_{i} \\
\left(10^{-3} \mathrm{x} \mathrm{s}^{-1}\right)\end{array}$ \\
\hline 1 & 23.5 & 15.7 & 420 & $\mathrm{n} / \mathrm{a}$ \\
2 & 17.3 & 11.5 & 555 & 3.1 \\
average & $20 \pm 4$ & $13 \pm 3$ & & \\
\hline
\end{tabular}



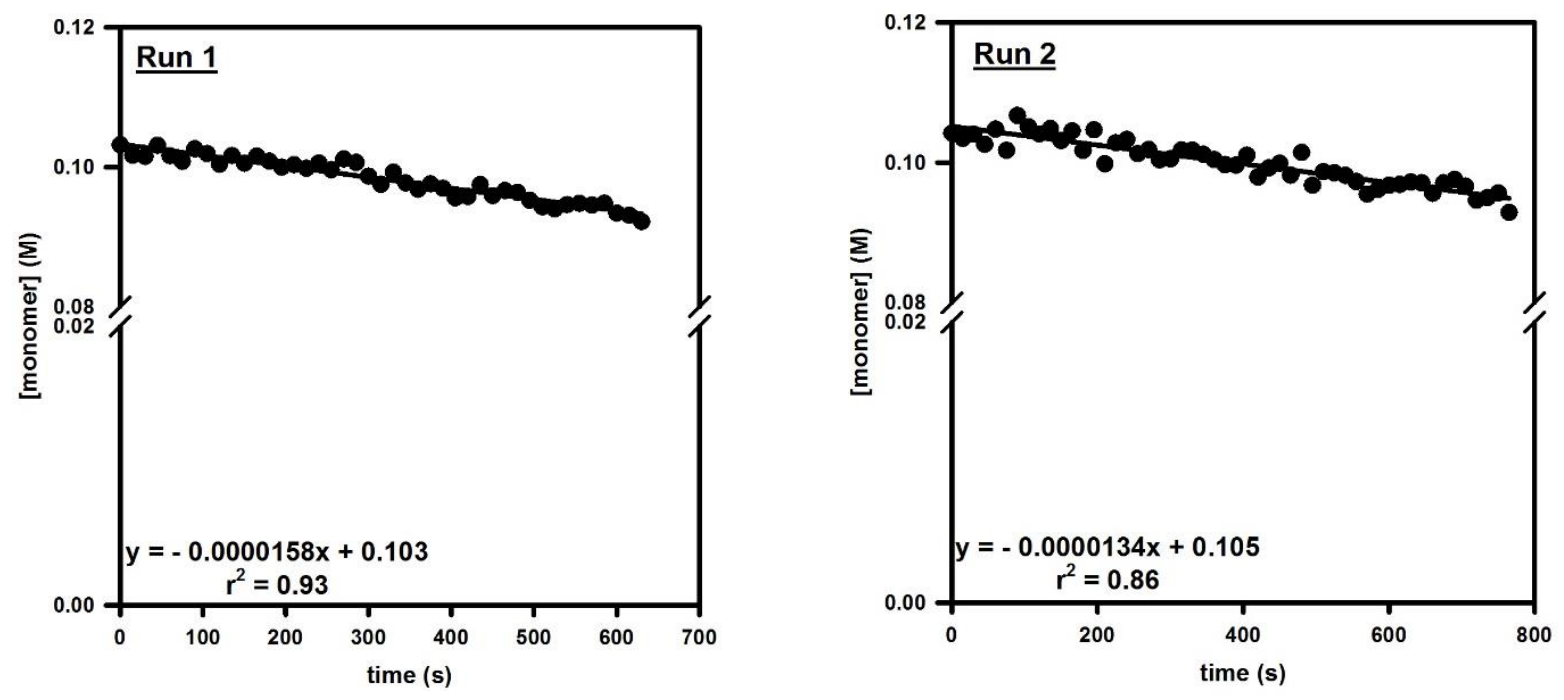

Figure S15. Plot of [monomer] versus time the polymerization catalyzed by $\mathbf{2 c}$. $\left(\right.$ temp $=0{ }^{\circ} \mathrm{C},[\mathbf{2 c}]$ $=0.0015 \mathrm{M}$, [monomer] $=0.10 \mathrm{M}$ (Run 1), 0.11M (Run 2)).

Table S3. Table of data for the plots in Figure S15.

\begin{tabular}{ccccc}
\hline Run & $\begin{array}{c}\text { Initial rate } \\
\left(10^{-6} \times \mathrm{M} \mathrm{s}^{-1}\right)\end{array}$ & $\begin{array}{c}k_{\text {obs }} \\
\left(10^{-3} \mathrm{x} \mathrm{s}^{-1}\right)\end{array}$ & $\begin{array}{c}\text { Time at } 10 \% \text { conversion } \\
(\mathrm{s})\end{array}$ & $\begin{array}{c}\text { Calculated } k_{i} \\
\left(10^{-3} \mathrm{x} \mathrm{s}^{-1}\right)\end{array}$ \\
\hline 1 & 15.8 & 10.5 & 630 & 2.35 \\
2 & 13.4 & 8.93 & 735 & 1.39 \\
average & $14 \pm 2$ & $9 \pm 1$ & & $1.9 \pm 0.6$ \\
\hline
\end{tabular}



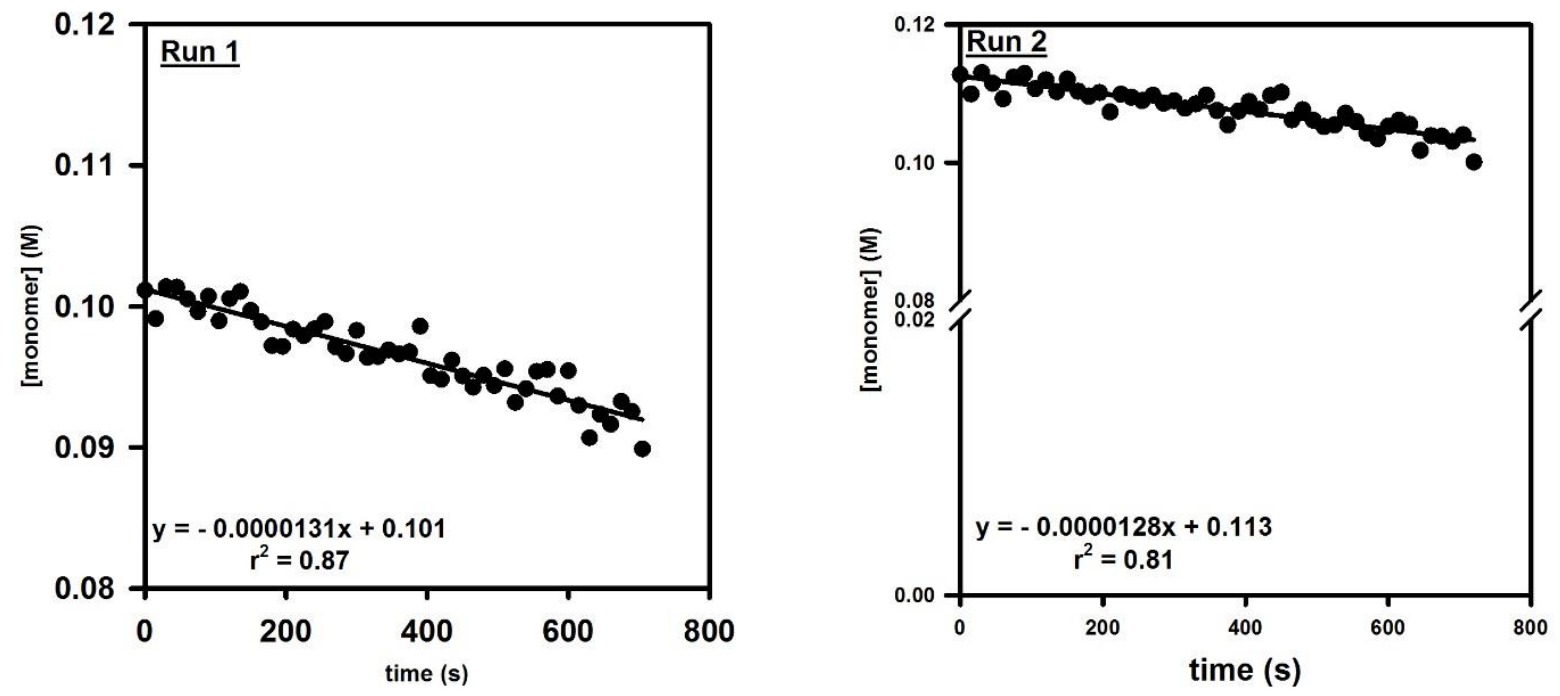

Figure S16. Plots of [monomer] versus time for the polymerization catalyzed by $2 \mathbf{d}$. (temp $=0{ }^{\circ} \mathrm{C}$, [2d] $=0.0015 \mathrm{M}$, [monomer] $=0.10 \mathrm{M}$ (Run 1), 0.10M (Run 2)). ${ }^{*}$ Due to low solubility of precatalyst 2d, a more dilute catalyst solution $(2.0 \mathrm{~mL}, 0.0075 \mathrm{M}, 0.015$ equiv) was used.

Table S4. Table of data for the plots in Figure S16.

\begin{tabular}{ccccc}
\hline Run & $\begin{array}{c}\text { Initial rate } \\
\left(10^{-6} \times \mathrm{M} \mathrm{s}^{-1}\right)\end{array}$ & $\begin{array}{c}k_{\text {obs }} \\
\left(10^{-3} \mathrm{x} \mathrm{s}^{-1}\right)\end{array}$ & $\begin{array}{c}\text { Time at } 10 \% \text { conversion } \\
(\mathrm{s})\end{array}$ & $\begin{array}{c}\text { Calculated } k_{i} \\
\left(10^{-3} \mathrm{x} \mathrm{s}^{-1}\right)\end{array}$ \\
\hline 1 & 13.1 & 8.56 & 705 & 1.38 \\
2 & 12.8 & 8.74 & 720 & 1.41 \\
average & $13.0 \pm 0.2$ & $8.7 \pm 0.1$ & & $1.40 \pm 0.02$ \\
\hline
\end{tabular}



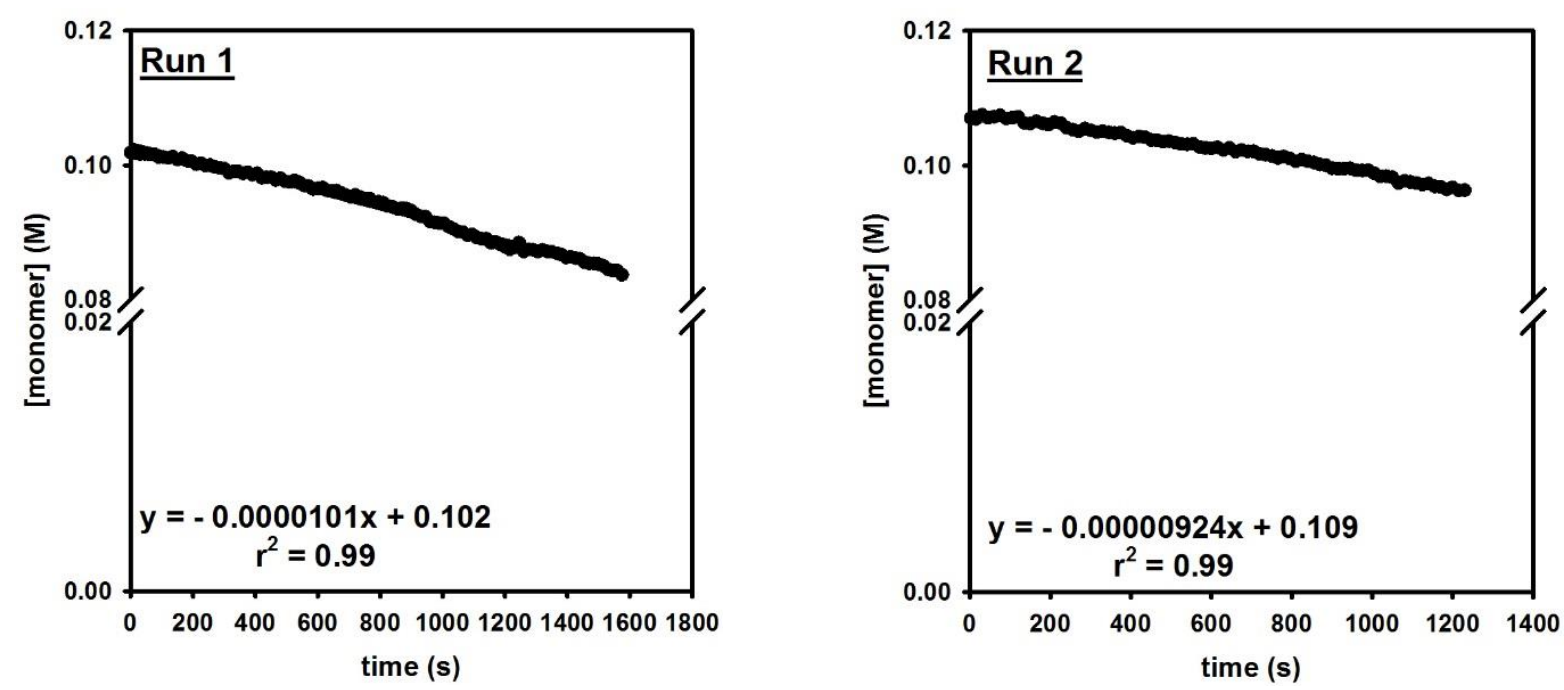

Figure S17. Plot of [monomer] versus time for the polymerization catalyzed by $2 \mathbf{e}$. (temp $=0{ }^{\circ} \mathrm{C}$, $[2 \mathrm{e}]=0.0015 \mathrm{M}$, [monomer] $=0.10 \mathrm{M}$ (Run 1), 0.11M (Run 2)).

Table S5. Table of data for the plot in Figure S17.

\begin{tabular}{ccccc}
\hline Run & $\begin{array}{c}\text { Initial rate } \\
\left(10^{-6} \times \mathrm{M} \mathrm{s}^{-1}\right)\end{array}$ & $\begin{array}{c}k_{\text {obs }} \\
\left(10^{-3} \times \mathrm{s} \mathrm{s}^{-1}\right)\end{array}$ & $\begin{array}{c}\text { Time at 10\% conversion } \\
(\mathrm{s})\end{array}$ & $\begin{array}{c}\text { Calculated } k_{i} \\
\left(10^{-3} \times \mathrm{x} \mathrm{s}^{-1}\right)\end{array}$ \\
\hline 1 & 10.08 & 7.95 & 990 & 0.656 \\
2 & 9.24 & 6.16 & 1260 & 0.616 \\
average & $9.7 \pm 0.6$ & $7 \pm 1$ & & $0.64 \pm 0.03$ \\
\hline
\end{tabular}



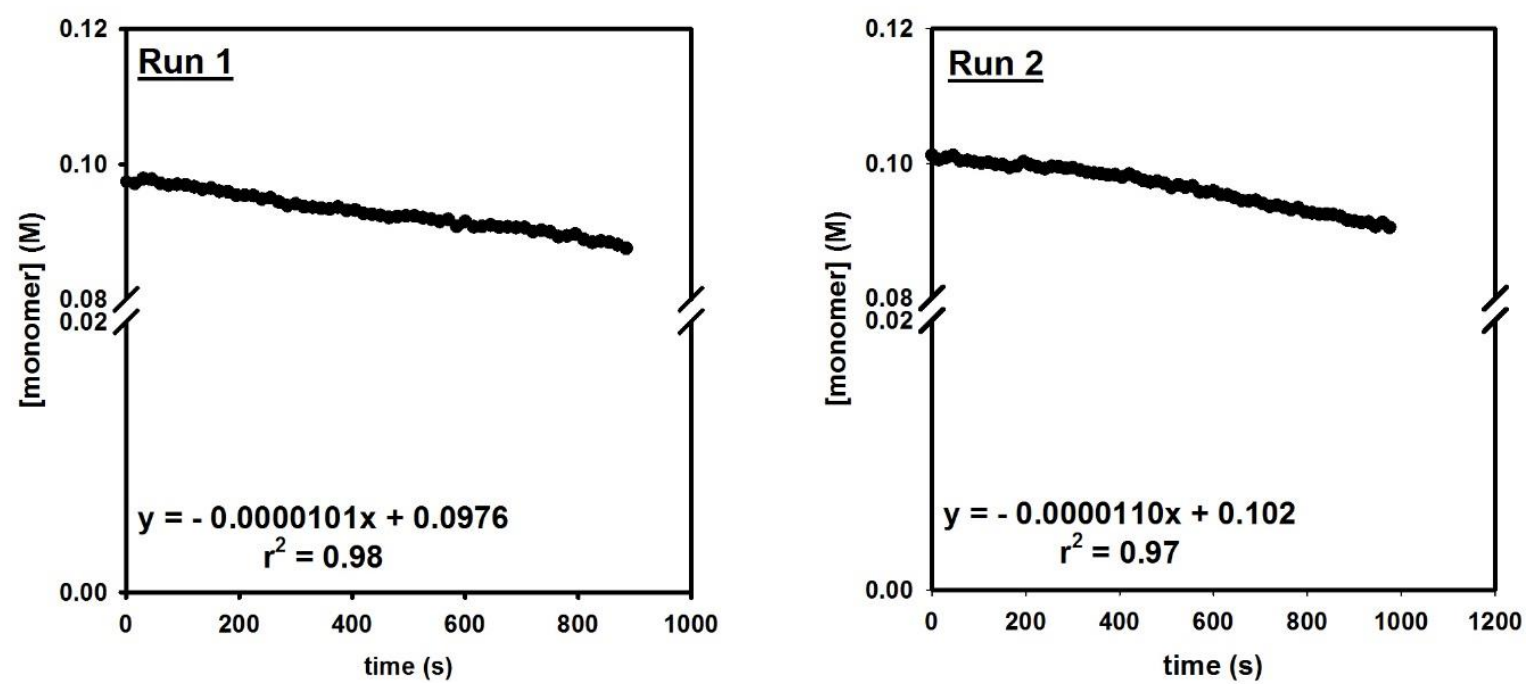

Figure S18. Plot of [monomer] versus time for the polymerization catalyzed by $\mathbf{2 e}$ with $\mathrm{PPh}_{3}$. $\left(\right.$ temp $=0{ }^{\circ} \mathrm{C},[2 \mathrm{e}]=0.0015 \mathrm{M},\left[\mathrm{PPh}_{3}\right]=0.0030$ [monomer] $=0.096 \mathrm{M}$ (Run 1), 0.11M (Run 2)).

Table S6. Table of data for the plot in Figure S18.

\begin{tabular}{ccccc}
\hline Run & $\begin{array}{c}\text { Initial rate } \\
\left(10^{-6} \times \mathrm{M} \mathrm{s}^{-1}\right)\end{array}$ & $\begin{array}{c}k_{\text {obs }} \\
\left(10^{-3} \mathrm{x} \mathrm{s}^{-1}\right)\end{array}$ & $\begin{array}{c}\text { Time at } 10 \% \text { conversion } \\
(\mathrm{s})\end{array}$ & $\begin{array}{c}\text { Calculated } k_{i} \\
\left(10^{-3} \mathrm{x} \mathrm{s}^{-1}\right)\end{array}$ \\
\hline 1 & 10.1 & 7.18 & 885 & 1.28 \\
2 & 11.0 & 7.35 & 975 & 1.00 \\
average & $10.6 \pm 0.7$ & $7.3 \pm 0.1$ & & $1.1 \pm 0.1$ \\
\hline
\end{tabular}



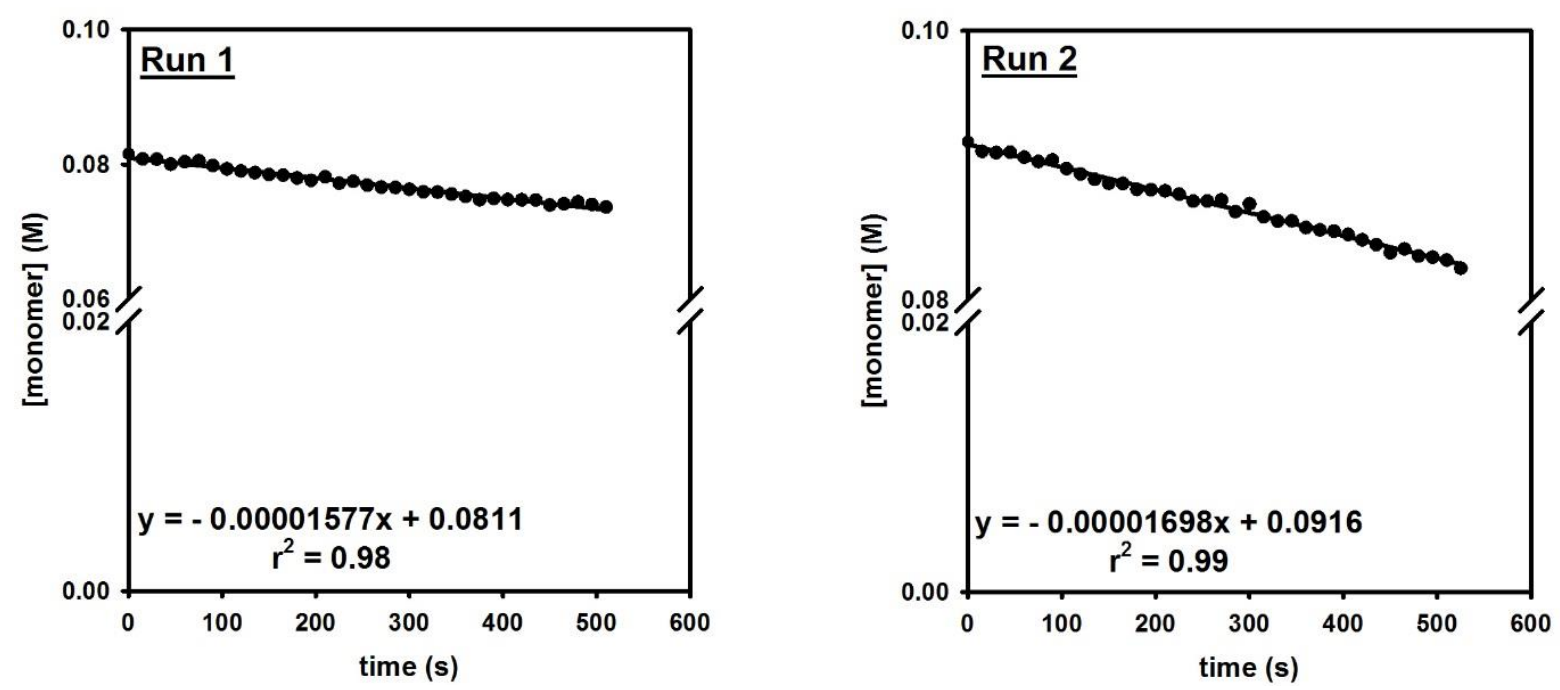

Figure S19. Plot of [monomer] versus time for the polymerization catalyzed by $2 \mathrm{f}$. (temp $=0{ }^{\circ} \mathrm{C}$, [2f] $=0.0015 \mathrm{M}$, [monomer] $=0.08 \mathrm{M}$ (Run 1), 0.09M (Run 2)). *Due to low solubility of precatalyst 2f, a more dilute catalyst solution $(3.0 \mathrm{~mL}, 0.005 \mathrm{M}, 0.015$ equiv) was used.

Table S6. Table of data for the plot in Figure S19. The initiation rate constant $k_{i}$ was not calculated because equation 1 fails when $k_{o b s}>k_{p}$.

\begin{tabular}{ccccc}
\hline Run & $\begin{array}{c}\text { Initial rate } \\
\left(10^{-6} \times \mathrm{M} \mathrm{s}^{-1}\right)\end{array}$ & $\begin{array}{c}k_{\text {obs }} \\
\left(10^{-3} \mathrm{x} \mathrm{s}^{-1}\right)\end{array}$ & $\begin{array}{c}\text { Time at } 10 \% \text { conversion } \\
(\mathrm{s})\end{array}$ & $\begin{array}{c}\text { Calculated } k_{i} \\
\left(10^{-3} \mathrm{x} \mathrm{s}^{-1}\right)\end{array}$ \\
\hline 1 & 15.77 & 10.5 & 570 & $\mathrm{n} / \mathrm{a}$ \\
2 & 16.98 & 11.3 & 465 & $\mathrm{n} / \mathrm{a}$ \\
average & $16.4 \pm 0.9$ & $10.9 \pm 0.6$ & & $\mathrm{n} / \mathrm{a}$ \\
\hline
\end{tabular}


In a glovebox under an $\mathrm{N}_{2}$ atmosphere a stock solution of precatalyst $2 \mathbf{e}(19.8 \mathrm{mg}, 0.0265 \mathrm{mmol})$ and $\mathrm{PPh}_{3}(15.1 \mathrm{mg}, 0.0557 \mathrm{mmol})$ was prepared in THF $(1 \mathrm{~mL})$. To this stock solution, $\alpha, \alpha, \alpha-$ trifluoromethyltoluene ( $26 \mu \mathrm{L}, 1.0 \mathrm{M}$ in THF) was added as an internal standard. A J. Young NMR tube was charged with this solution $(0.8 \mathrm{~mL})$, sealed with a septum, and cooled to $0{ }^{\circ} \mathrm{C}$ in the spectrometer for approx. $45 \mathrm{~min}$. A solution of (4-chloro-2,5-dimethoxyphenyl)magnesium chloride ( $0.2 \mathrm{~mL}, 0.2 \mathrm{M}$ in THF, 2.0 equiv) was added, and the tube was inverted once to mix. The final solution contained $0.02 \mathrm{mmol}$ precatalyst, $0.04 \mathrm{mmol} \mathrm{PPh}_{3}, 0.02 \mathrm{mmol} \alpha, \alpha, \alpha-$ trifluoromethyltoluene, and $0.04 \mathrm{mmol}$ (4-chloro-2,5-dimethoxyphenyl)magnesium chloride. All ${ }^{19} \mathrm{~F}$ NMR spectra were acquired with acquisition time $=1.5 \mathrm{~s}$, relaxation time $=3 \mathrm{~s}$, scan size $=4$.

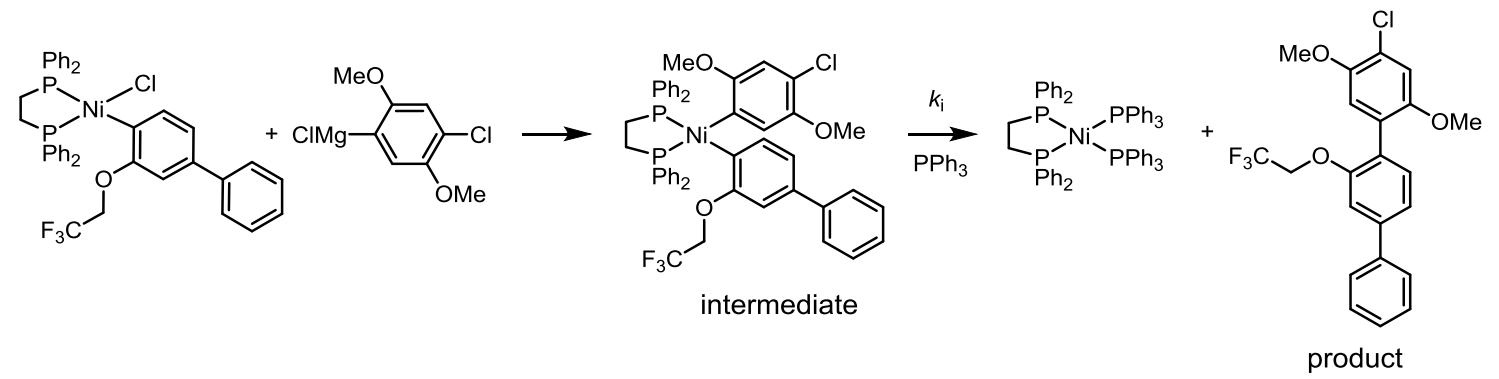

Scheme 1. Initiation of precatalyst $2 e$ 
${ }^{19}$ F NMR spectra

${ }^{31}$ P NMR spectra
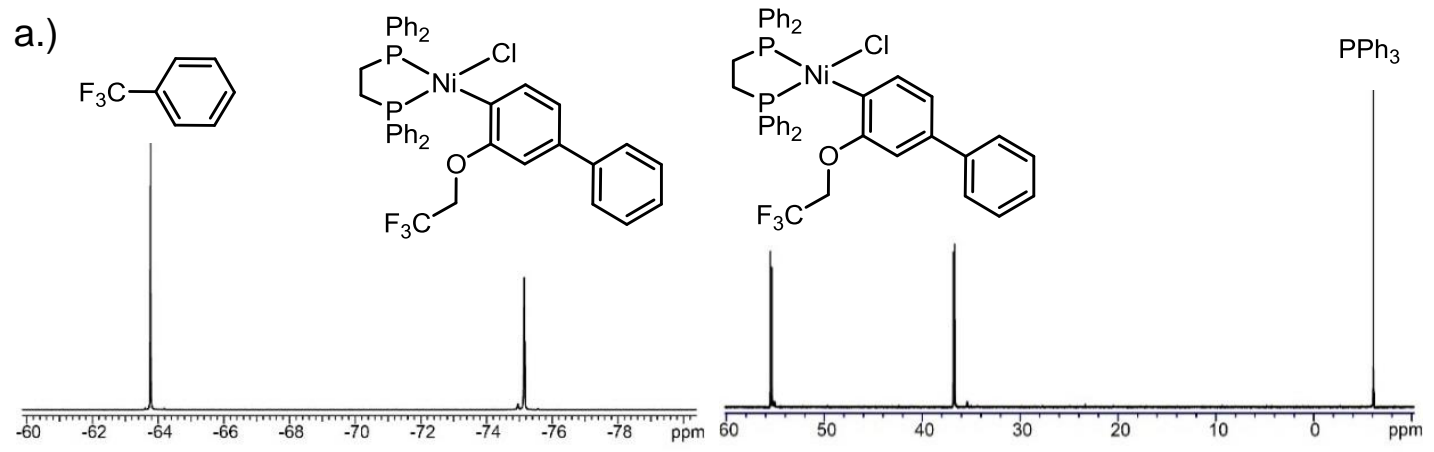

b.)
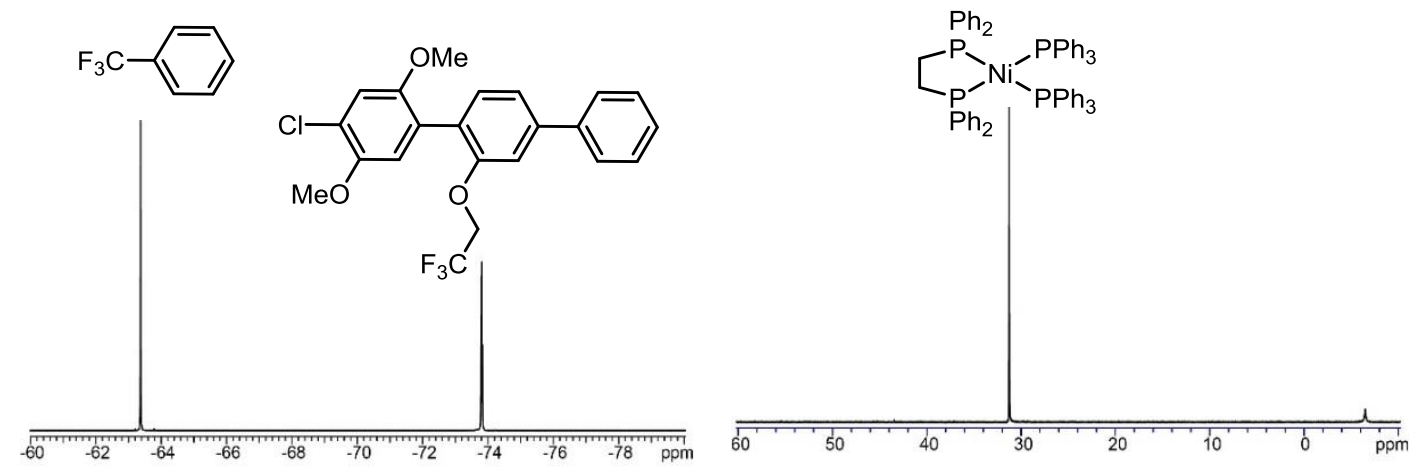

Figure S20. (a) ${ }^{19} \mathrm{~F}$ and ${ }^{31} \mathrm{P}$ NMR spectra at the beginning and (b) end of the reaction in Scheme 1. 


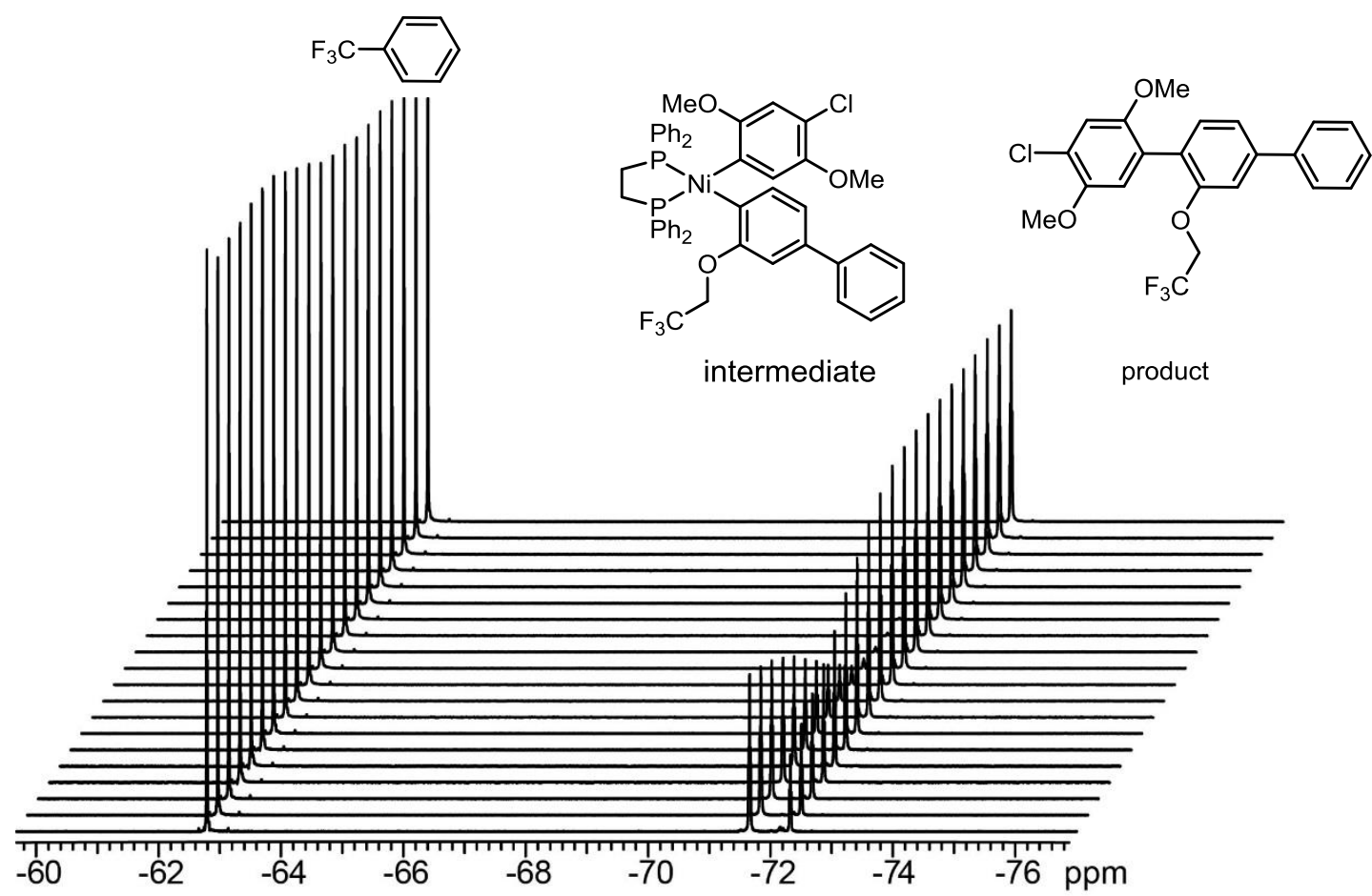

Figure S21. Representative ${ }^{19} \mathrm{~F}$ NMR spectral array for precatalyst 2e. Concentrations were calculated relative to an internal standard, $\alpha, \alpha, \alpha$-trifluoromethyltoluene.

\section{Procedure for Calculating Concentrations from Integrals}

The internal standard concentration was used to calculate the ratio of integration:concentration, which was then used to calculate concentrations of the intermediate and product peaks from the integrals.

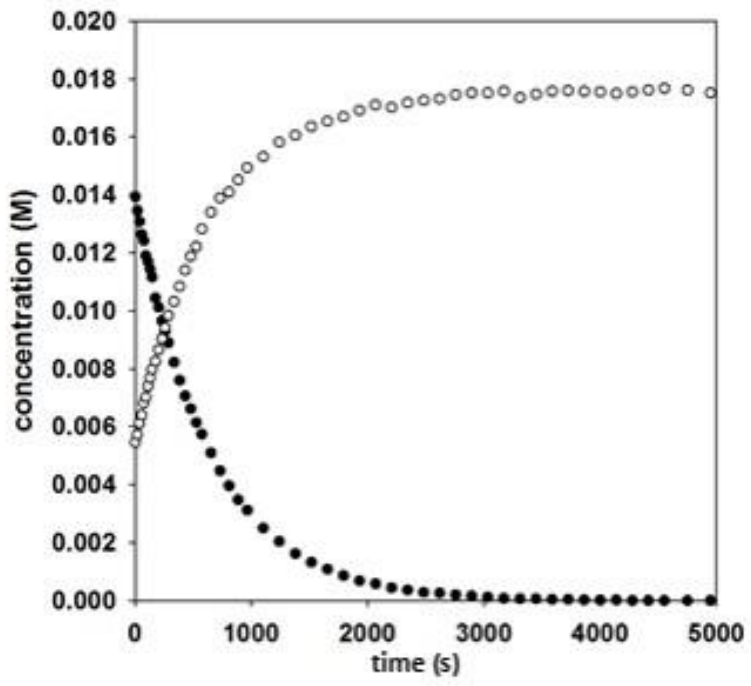

Figure S22. Plot of concentration of intermediate $(\bullet)$ and product $(\circ)$ versus time for the data in Figure S21. 


\section{Procedure for Calculating Rate Constants in Igor Pro}

Initiation rate constants were calculated using Igor Pro v.6.22A, following the procedure in "Fitting to Differential equations in Igor Pro" provided by the Collum group ${ }^{4}$ and using Collum Kinetic 5000 as the master procedure file. The data was fit to the following equations:

$$
\begin{aligned}
& \frac{d[\text { intermediate }]}{d t}=-k_{i} \times[\text { intermediate }] \\
& \frac{d[\text { product }]}{d t}=k_{i} \times[\text { intermediate }]
\end{aligned}
$$

Table S7. Initiation rate constants for $2 e$

\begin{tabular}{cc}
\hline Run & $\begin{array}{c}k_{i} \\
\left(10^{-3} \times \mathrm{x}^{-1}\right)\end{array}$ \\
\hline 1 & 1.310 \\
2 & 1.307 \\
average & $1.309 \pm 0.002$ \\
\hline
\end{tabular}




\section{Polymerization}

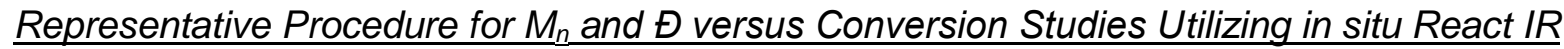
Spectroscopy:

The IR probe was inserted through an O-ring-sealed 14/20 ground-glass adapter (custommade) into an oven-dried $50 \mathrm{~mL}$ 2-neck flask equipped with a stir bar. The other neck was fitted with a three-way flow-control adapter with a septum for injections/aliquot sampling and an $\mathrm{N}_{2}$ line. The oven-dried flask was cooled under vacuum, then filled with $\mathrm{N}_{2}$. The flask was reevacuated and filled for two additional cycles. The flask was charged with THF $(6.7 \mathrm{~mL})$ and cooled to $0{ }^{\circ} \mathrm{C}$ for $15 \mathrm{~min}$. After recording a background spectrum, monomer $1(2.3 \mathrm{~mL}, 0.44 \mathrm{M}$ in THF, 1.0 equiv) was added by syringe and equilibrated at $0{ }^{\circ} \mathrm{C}$ for at least $5 \mathrm{~min}$. Then the precatalyst solution ( $1.0 \mathrm{~mL}, 0.015 \mathrm{M}, 0.015$ equiv) was injected and spectra were recorded every $15 \mathrm{~s}$. To account for mixing and temperature equilibration, spectra recorded in the first 60 $s$ were not analyzed. Aliquots (approx. $0.5 \mathrm{~mL}$ ) were taken via syringe and immediately quenched with aq. $\mathrm{HCl}$ (approx. $1 \mathrm{~mL}, 12 \mathrm{M}$ ). The resulting solution was then extracted with $\mathrm{CH}_{2} \mathrm{Cl}_{2}(2 \times 1.5 \mathrm{~mL})$ (with mild heating if polymer had precipitated), dried over $\mathrm{MgSO}_{4}$, filtered, and then concentrated. At approximately $80 \%$ conversion, the polymerization was poured into aq. $\mathrm{HCl}(20 \mathrm{~mL}, 12 \mathrm{M})$, extracted with $\mathrm{CH}_{2} \mathrm{Cl}_{2}(3 \times 25 \mathrm{~mL})$, washed with $\mathrm{H}_{2} \mathrm{O}(1 \times 25 \mathrm{~mL})$, brine ( $1 \times 25 \mathrm{~mL}$ ), dried over $\mathrm{MgSO}_{4}$, filtered, and concentrated. The samples (both aliquots and the final reaction mixture) were each dissolved in THF (with heating), and passed through a $0.2 \mu \mathrm{m}$ poly(tetrafluoroethylene) filter for analysis by gel permeation chromatography (GPC). The monomer conversion versus time data was calculated from the IR spectra using a calibration curve. 

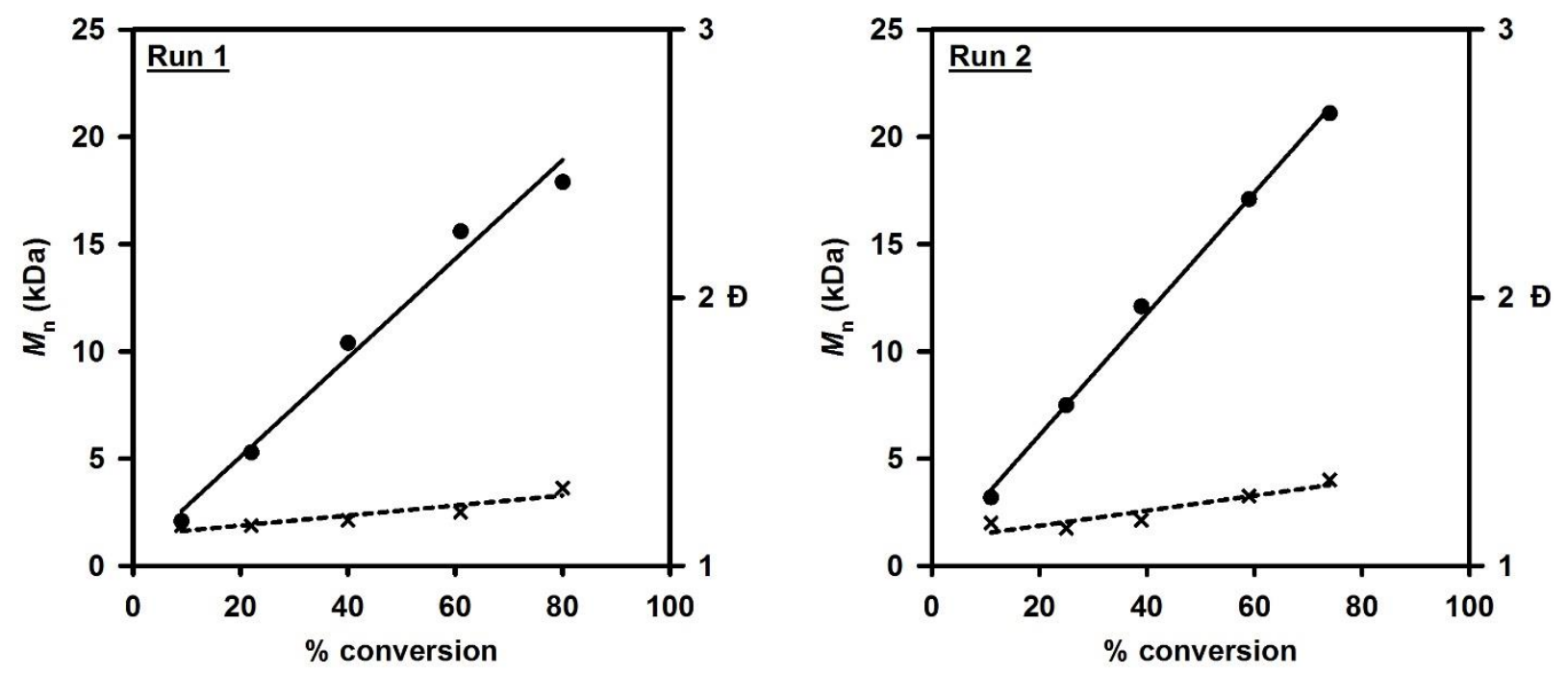

Figure S23. Plot of $M_{\mathrm{n}}(\bullet)$ and $Đ(\mathbf{x})$ versus conversion for $\mathbf{2 b}\left(\right.$ temp $=0{ }^{\circ} \mathrm{C},[\mathbf{2 b}]=0.0015 \mathrm{M}$, [monomer] $=0.11 \mathrm{M}($ Run 1$), 0.11 \mathrm{M}($ Run 2)) .

Table S8. Data for the plot in Figure S23, Run 1.

\begin{tabular}{ccc}
\hline \% Conversion & $M_{\mathrm{n}}(\mathrm{kDa})$ & $\bigoplus$ \\
\hline 9 & 2.1 & 1.15 \\
22 & 5.3 & 1.15 \\
40 & 10.4 & 1.17 \\
61 & 15.6 & 1.20 \\
80 & 17.9 & 1.29 \\
\hline
\end{tabular}

Table S9. Data for the plot in Figure S23, Run 2.

\begin{tabular}{ccc}
\hline \% Conversion & $M_{\mathrm{n}}(\mathrm{kDa})$ & $\bigoplus$ \\
\hline 11 & 3.2 & 1.16 \\
25 & 7.5 & 1.14 \\
39 & 12.1 & 1.17 \\
59 & 17.1 & 1.26 \\
74 & 21.1 & 1.32 \\
\hline
\end{tabular}



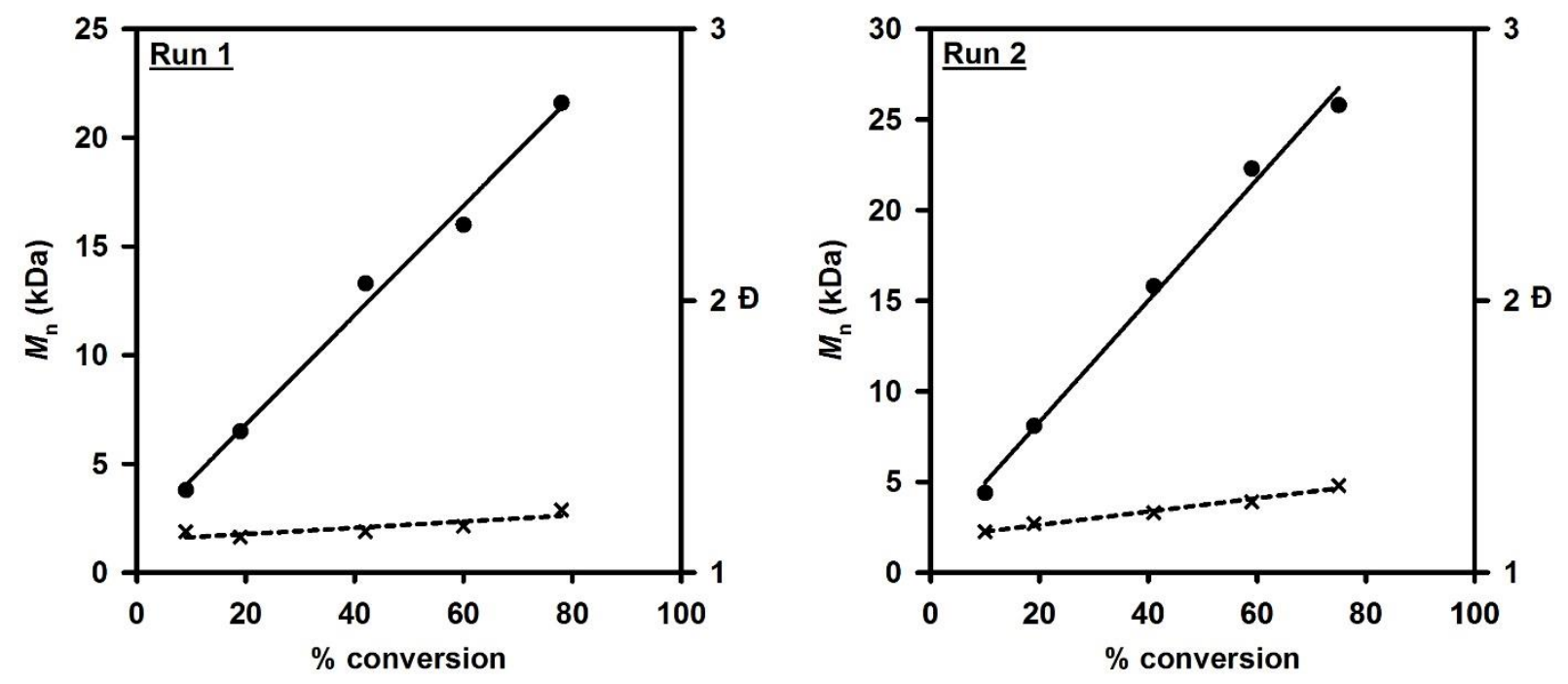

Figure S24. Plot of $M_{\mathrm{n}}(\bullet)$ and $\boxminus(\mathbf{x})$ versus conversion for $2 \mathbf{c}\left(\right.$ temp $=0{ }^{\circ} \mathrm{C},[\mathbf{2 c}]=0.0015 \mathrm{M}$, [monomer] $=0.10 \mathrm{M}$ (Run 1), 0.10M (Run 2)).

Table S10. Data for the plot in Figure S24, Run 1.

\begin{tabular}{ccc}
\hline \% Conversion & $M_{\mathrm{n}}(\mathrm{kDa})$ & Ð \\
\hline 9 & 3.8 & 1.15 \\
19 & 6.5 & 1.13 \\
42 & 13.3 & 1.15 \\
60 & 16.0 & 1.17 \\
78 & 21.6 & 1.23 \\
\hline
\end{tabular}

Table S11. Data for the plot in Figure S24, Run 2.

\begin{tabular}{ccc}
\hline \% Conversion & $M_{\mathrm{n}}(\mathrm{kDa})$ & $Ð$ \\
\hline 10 & 4.4 & 1.15 \\
19 & 8.1 & 1.18 \\
41 & 15.8 & 1.22 \\
59 & 22.3 & 1.26 \\
75 & 25.8 & 1.32 \\
\hline
\end{tabular}



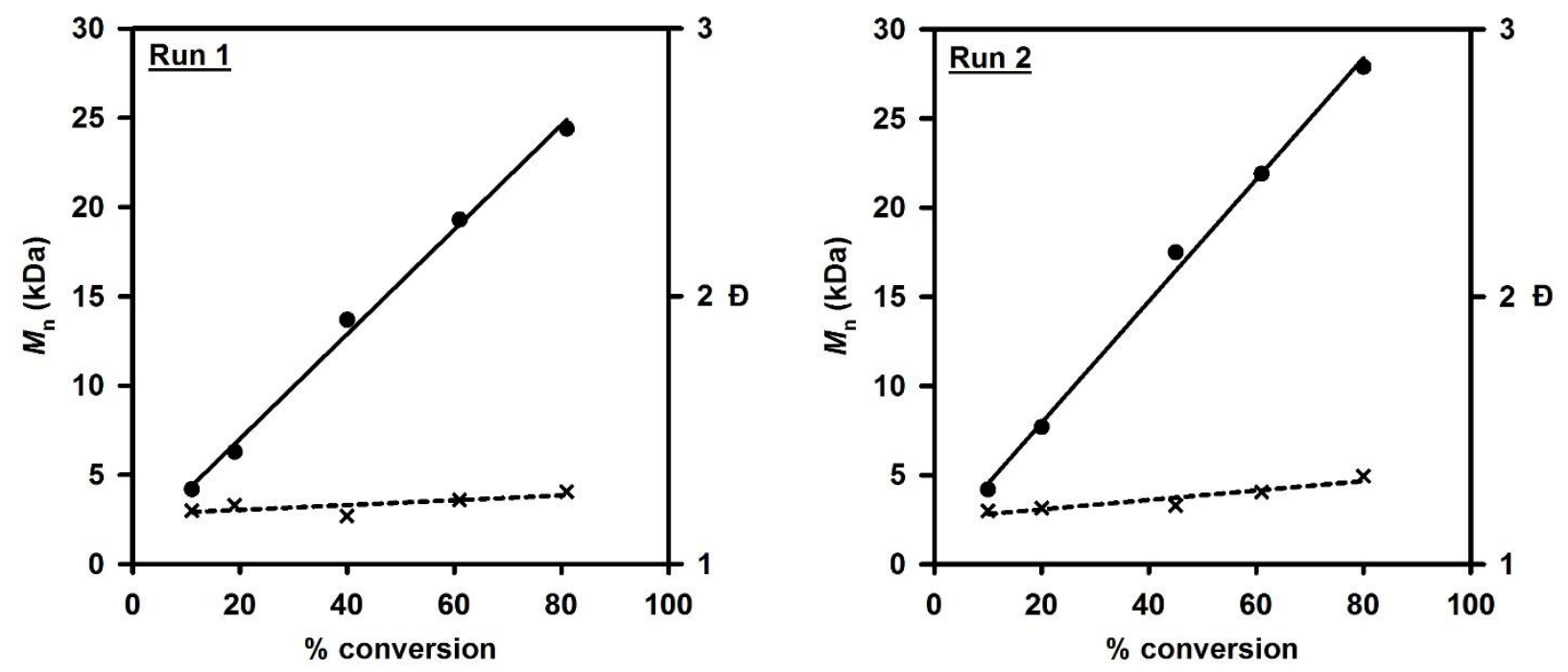

Figure S25. Plot of $M_{\mathrm{n}}(\bullet)$ and $\boxminus(\mathbf{x})$ versus conversion for $\mathbf{2 d}\left(\right.$ temp $=0{ }^{\circ} \mathrm{C},[\mathbf{2 d}]=0.0015 \mathrm{M}$, [monomer] $=0.10 \mathrm{M}$ (Run 1), $0.11 \mathrm{M}$ (Run 2)). ${ }^{*}$ Due to low solubility of precatalyst $\mathbf{2 d}$, a dilute precatalyst solution $(2.0 \mathrm{~mL}, 0.0075 \mathrm{M}, 0.015$ equiv) was used.

Table S12. Data for the plot in Figure S25, Run 1.

\begin{tabular}{ccc}
\hline \% Conversion & $M_{\mathrm{n}}(\mathrm{kDa})$ & $Đ$ \\
\hline 11 & 4.2 & 1.20 \\
19 & 6.3 & 1.22 \\
40 & 13.7 & 1.18 \\
61 & 19.3 & 1.24 \\
81 & 24.4 & 1.27 \\
\hline
\end{tabular}

Table S13. Data for the plot in Figure S25, Run 2.

\begin{tabular}{ccc}
\hline \% Conversion & $M_{\mathrm{n}}(\mathrm{kDa})$ & Đ \\
\hline 10 & 4.2 & 1.20 \\
20 & 7.7 & 1.21 \\
45 & 17.5 & 1.22 \\
61 & 21.9 & 1.27 \\
80 & 27.9 & 1.33 \\
\hline
\end{tabular}



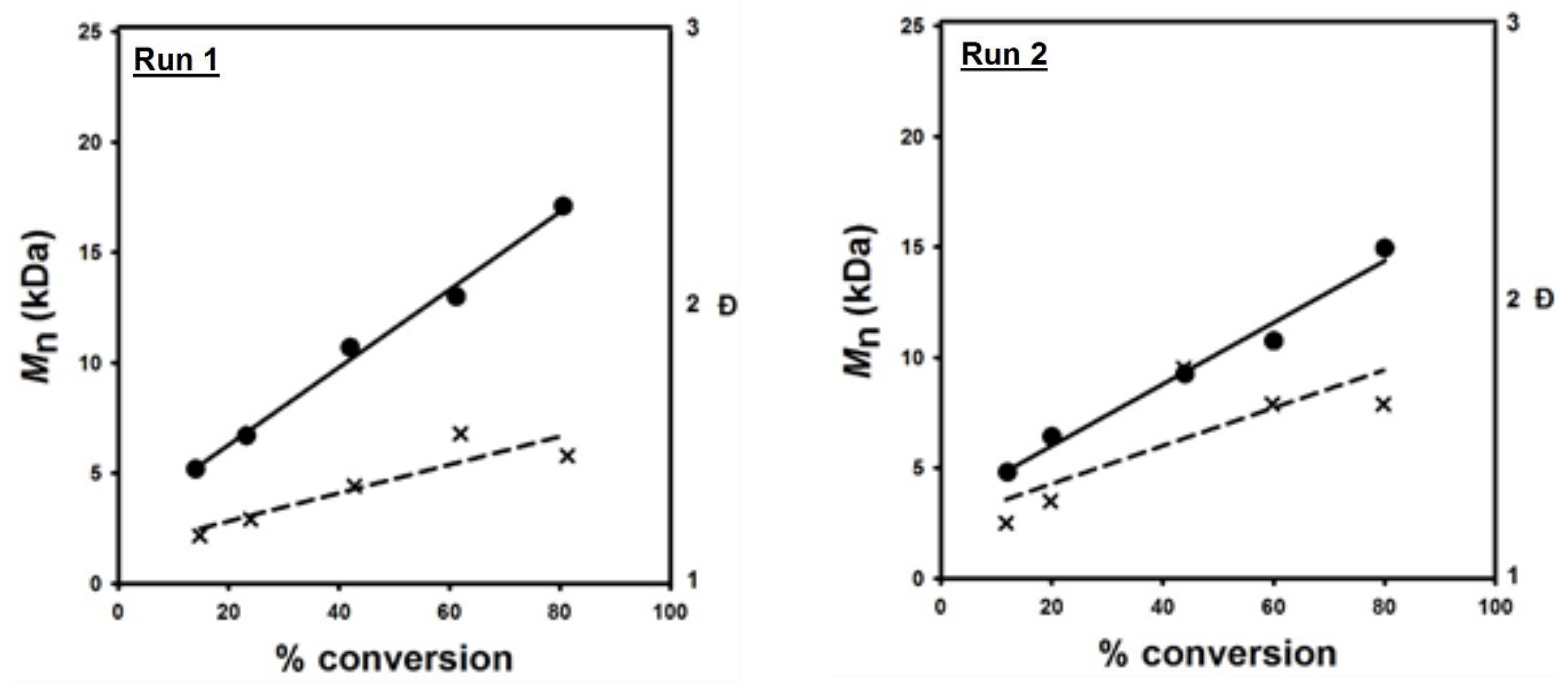

Figure S26. Plot of $M_{\mathrm{n}}(\bullet)$ and $\boxminus(\mathbf{x})$ versus conversion for $\mathbf{2 e}\left(\right.$ temp $=0{ }^{\circ} \mathrm{C},[\mathbf{2 e}]=0.0015 \mathrm{M}$, $[$ monomer] $=0.10 \mathrm{M}$ (Run 1), 0.11M (Run 2)).

Table S14. Data for the plot in Figure S26, Run 1.

\begin{tabular}{ccc}
\hline \% Conversion & $M_{\mathrm{n}}(\mathrm{kDa})$ & $Đ$ \\
\hline 14 & 5.2 & 1.16 \\
23 & 6.7 & 1.22 \\
42 & 10.7 & 1.34 \\
61 & 13.0 & 1.53 \\
81 & 17.1 & 1.45 \\
\hline
\end{tabular}

Table S15. Data for the plot in Figure S26, Run 2.

\begin{tabular}{ccc}
\hline \% Conversion & $M_{\mathrm{n}}(\mathrm{kDa})$ & $Đ$ \\
\hline 12 & 4.8 & 1.19 \\
20 & 6.4 & 1.27 \\
44 & 9.3 & 1.55 \\
60 & 10.8 & 1.75 \\
80 & 15.0 & 1.62 \\
\hline
\end{tabular}


a.
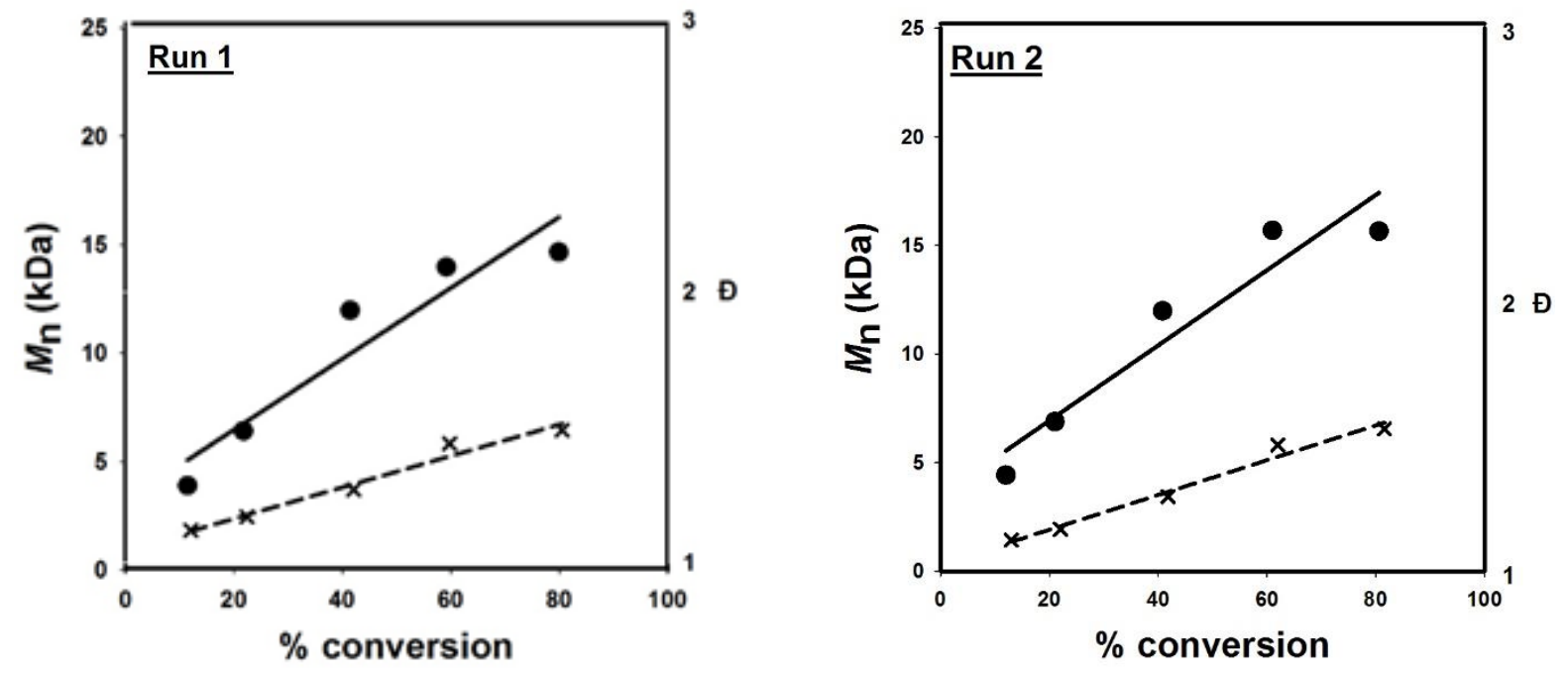

b.
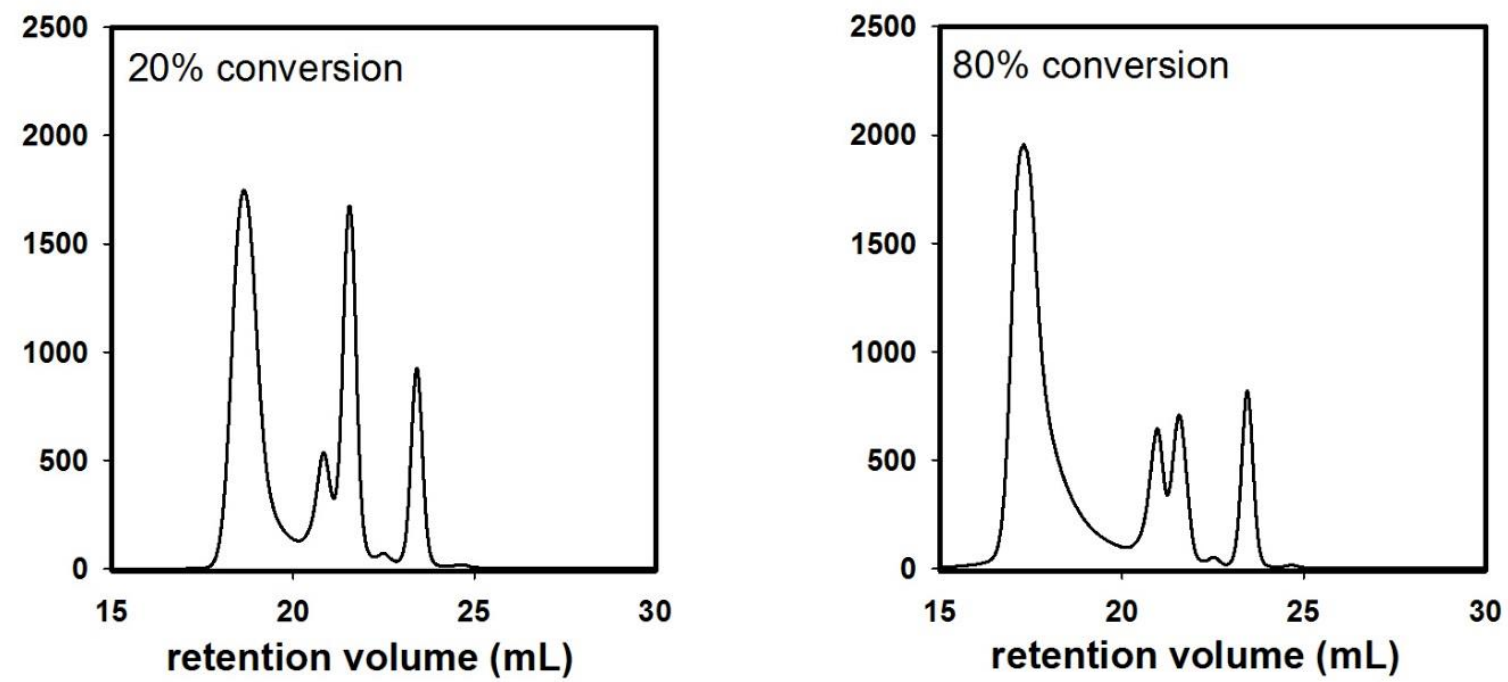

Figure S27. a.) Plot of $M_{\mathrm{n}}(\bullet)$ and $Đ(\mathbf{x})$ versus conversion for $\mathbf{2 f}\left(\right.$ temp $=0{ }^{\circ} \mathrm{C},[\mathbf{2 f}]=0.0015 \mathrm{M}$, [monomer] $=0.082 \mathrm{M}$ (Run 1), 0.90M (Run 2)). *Due to low solubility of precatalyst $\mathbf{2 f}$, a dilute catalyst solution ( $3.0 \mathrm{~mL}, 0.005 \mathrm{M}, 0.015$ equiv) was used. b.) GPC curves of aliquots removed at 20 and $80 \%$ monomer conversion during Run 1.

Table S16. Data for the plot in Figure S27a, Run 1.

\begin{tabular}{ccc}
\hline \% Conversion & $M_{\mathrm{n}}(\mathrm{kDa})$ & Đ \\
\hline 11 & 3.9 & 1.12 \\
22 & 6.4 & 1.17 \\
41 & 12.0 & 1.27 \\
59 & 14.0 & 1.44 \\
80 & 14.7 & 1.49 \\
\hline
\end{tabular}


Table S17. Data for the plot in Figure S27b, Run 2.

\begin{tabular}{ccc}
\hline \% Conversion & $M_{\mathrm{n}}(\mathrm{kDa})$ & $\Xi$ \\
\hline 12 & 4.4 & 1.13 \\
21 & 6.9 & 1.17 \\
41 & 12.0 & 1.29 \\
61 & 15.7 & 1.48 \\
81 & 15.6 & 1.54 \\
\hline
\end{tabular}


a.

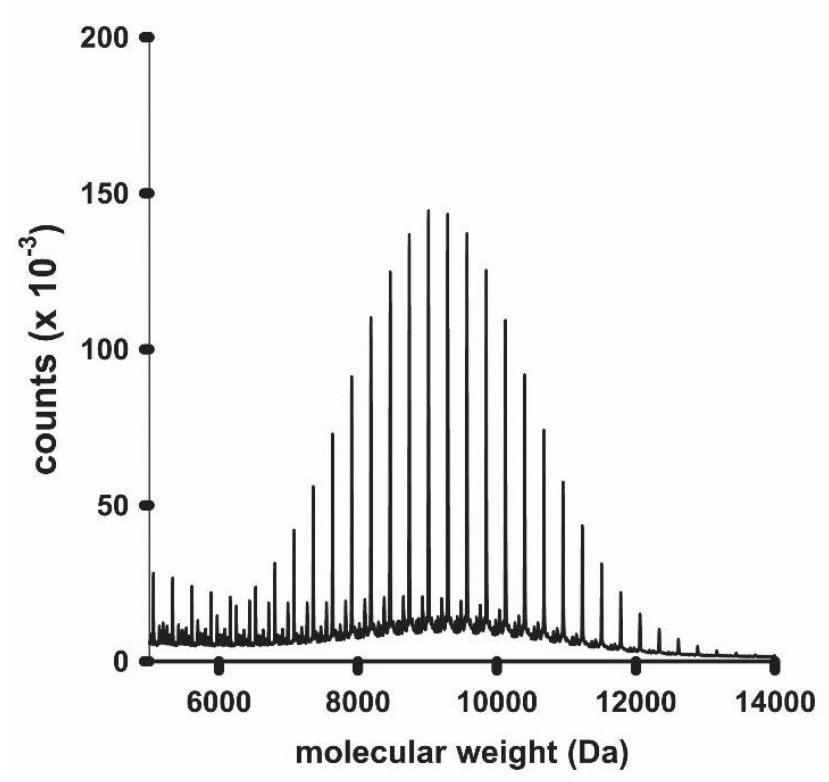

C.

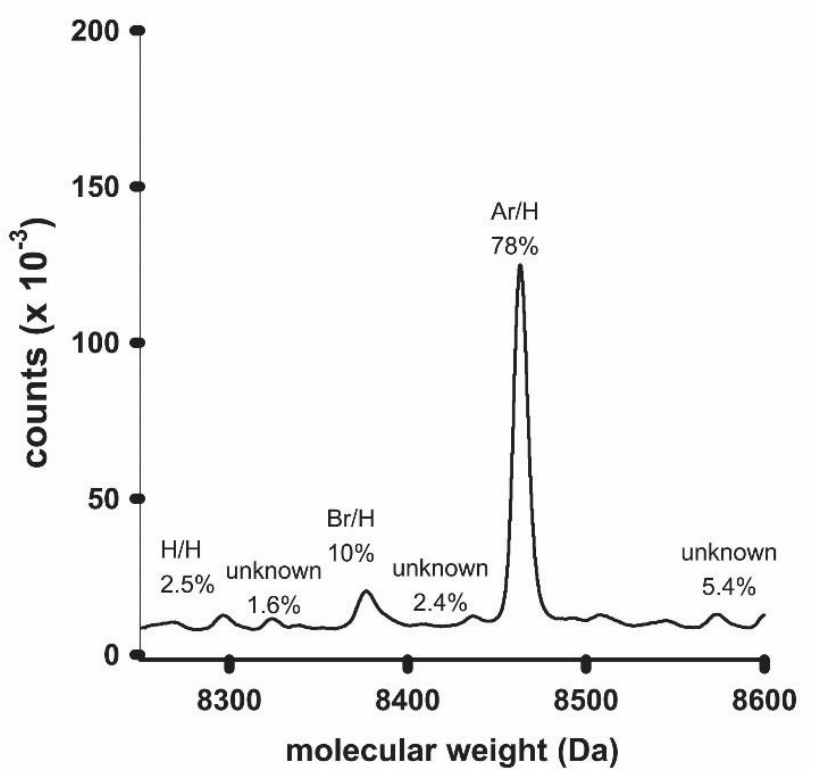

b.

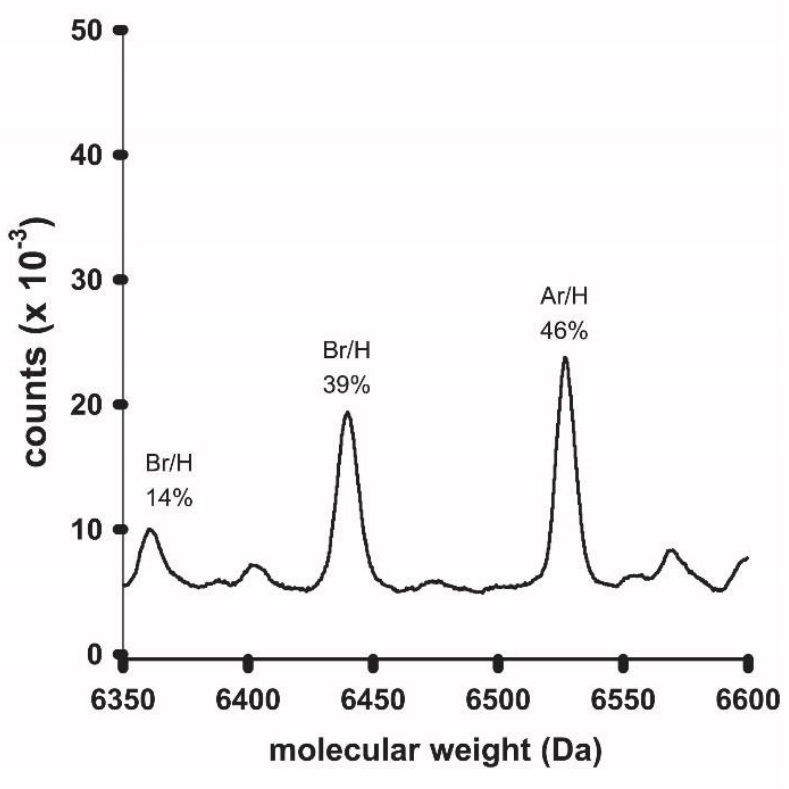

Figure S28. a. Full MALDI-TOF MS spectrum of polyphenylene initiated with precatalyst $\mathbf{2 b}$, b., MALDI-TOF MS spectrum at 23 repeat units, and c., MALDI-TOF MS spectrum at 30 repeat units. The polymer sample analyzed was from an aliquot was taken at $20 \%$ conversion for the polymer described in Figure S23. Lower molecular weight polymers had a higher percentage of $\mathrm{Br} / \mathrm{H}$ terminated polymers. 
a.

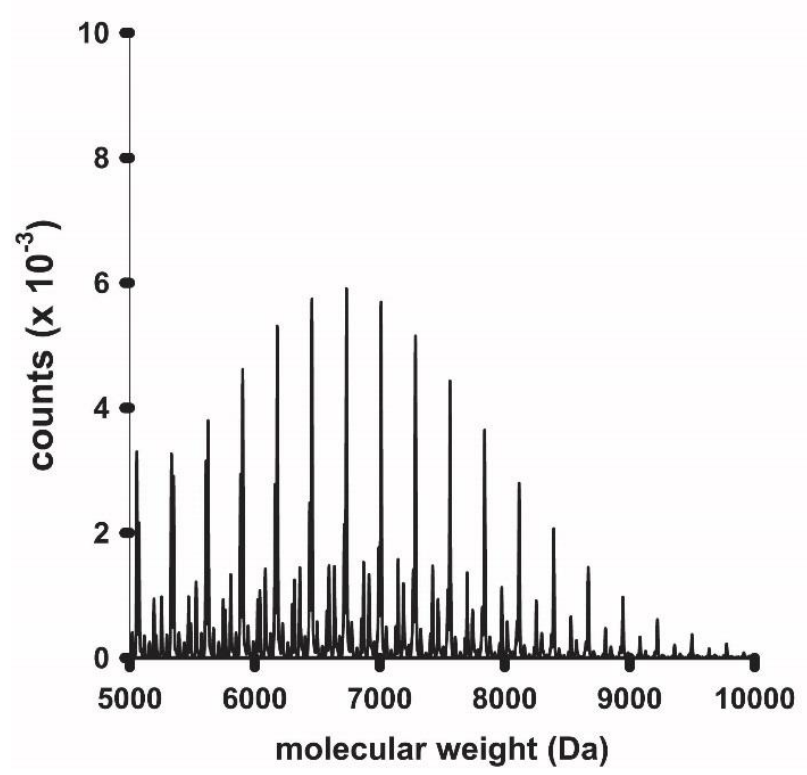

b.

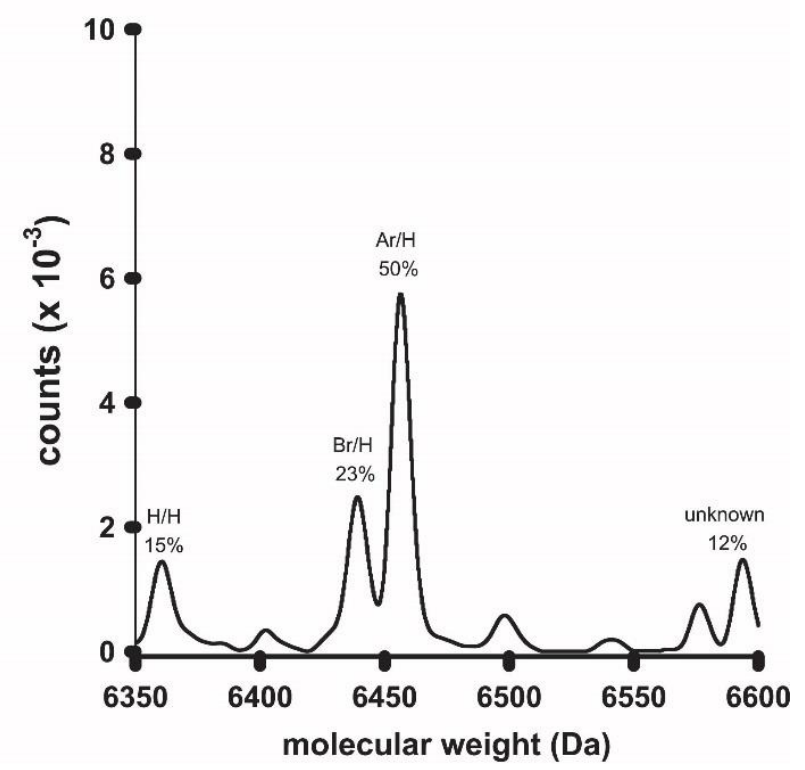

Figure S29. a. Full MALDI-TOF MS spectrum of polyphenylene initiated with precatalyst 2c, and b., MALDI-TOF MS spectrum at 23 repeat units. The polymer sample analyzed was from an aliquot was taken at 20\% conversion for the polymer described in Figure S24.

a.

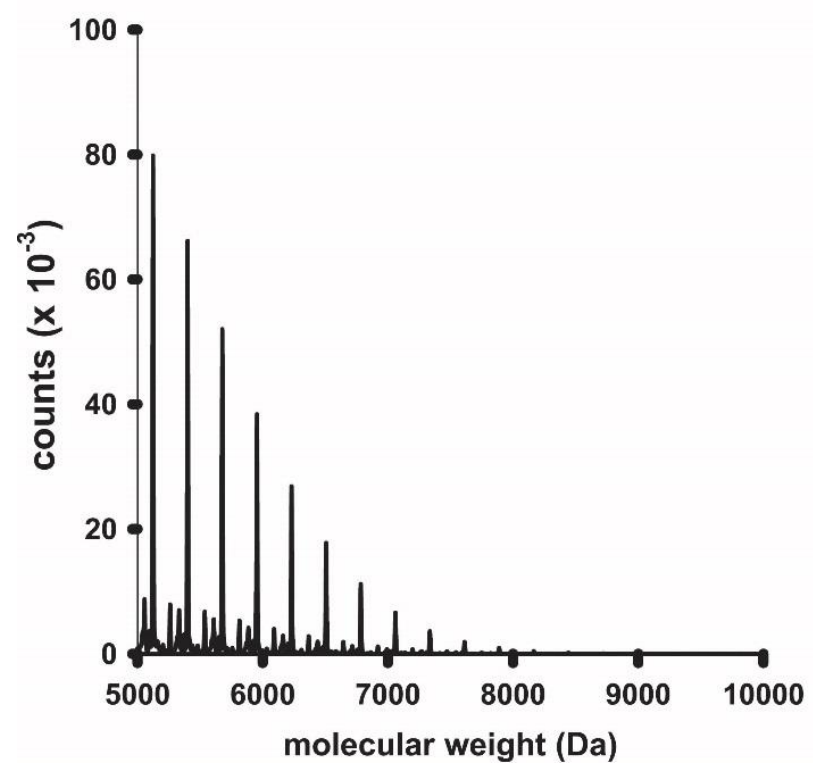

b.

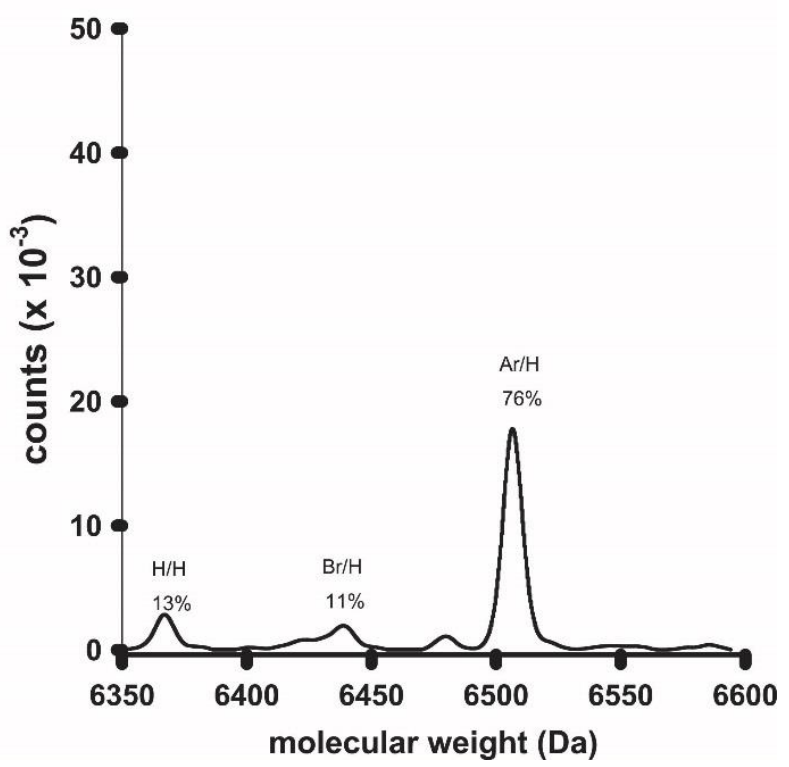

Figure S30. a. Full MALDI-TOF MS spectrum of polyphenylene initiated with precatalyst $\mathbf{2 d}$, and b., MALDI-TOF MS spectrum at 23 repeat units. The polymer sample analyzed was from an aliquot was taken at $20 \%$ conversion for the polymer described in Figure S25. 
Representative Procedure for Preparation of Polymers to Compare End-group Fidelity with Three dppe-Based Precatalysts:

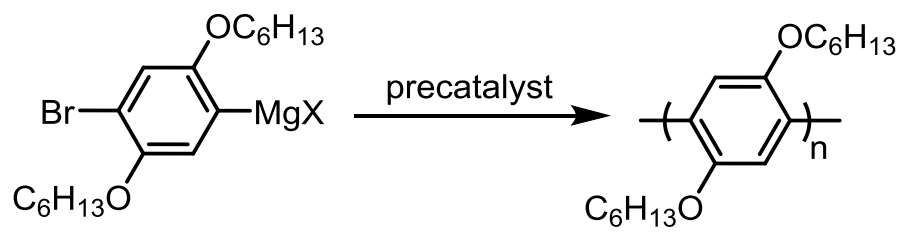

In a glovebox, a precatalyst stock solution was made by combining $2 \mathrm{f}(11.2 \mathrm{mg}, 0.0165 \mathrm{mmol})$ with THF $\left(3.3 \mathrm{~mL}\right.$ ) in a $4 \mathrm{~mL}$ vial. (Note: For $\mathrm{Ni}(\mathrm{dppe}) \mathrm{Cl}_{2}$, a pre-initiation protocol was followed wherein monomer $1(0.23 \mathrm{~mL}, 5$ equiv) was added to the precatalyst and stirred until homogeneous). The precatalyst solution $(3.0 \mathrm{~mL}, 0.015 \mathrm{mmol}, 1$ equiv) and THF (3.8 mL) were combined in a $50 \mathrm{~mL}$ Schlenk tube, sealed with a Teflon stopper, and then removed from the glovebox and put under $\mathrm{N}_{2}$ pressure. The solution was cooled to $0{ }^{\circ} \mathrm{C}$ for $20 \mathrm{~min}$. Then monomer solution (3.2 mL, $1.0 \mathrm{mmol}$, 66 equiv) was added. After $30 \mathrm{~min}$, an aliquot was removed by syringe, then quenched with aq. $\mathrm{HCl}$ (approx. $1.0 \mathrm{~mL}, 12 \mathrm{M}$ ), extracted with $\mathrm{CH}_{2} \mathrm{Cl}_{2}(2 \times 1 \mathrm{~mL}$ ), dried over $\mathrm{MgSO}_{4}$, filtered, concentrated, and then analyzed by MALDI-TOF MS analysis (SI). After $4 \mathrm{~h}$, the polymerization was poured in aq. $\mathrm{HCl}(20 \mathrm{~mL}, 12 \mathrm{M})$, extracted with $\mathrm{CH}_{2} \mathrm{Cl}_{2}(3 \times 25$ $\mathrm{mL})$, washed with water $(1 \times 25 \mathrm{~mL})$, brine $(1 \times 25 \mathrm{~mL})$, dried over $\mathrm{MgSO}_{4}$, filtered, and concentrated. Both the aliquot and the bulk polymerization were analyzed by GPC.

\begin{tabular}{ccc}
\hline Precatalyst & $M_{\mathrm{n}}(\mathrm{kDa})$ & $\bigoplus$ \\
\hline $\mathbf{2 f}$ & 16.1 & 1.45 \\
$\mathrm{Ni}(\mathrm{dppe})(\mathrm{tol}) \mathrm{Br}$ & 18.4 & 1.54 \\
$\mathrm{Ni}(\mathrm{dppe}) \mathrm{Cl}_{2}$ & 23.0 & 1.41 \\
\hline
\end{tabular}


a.

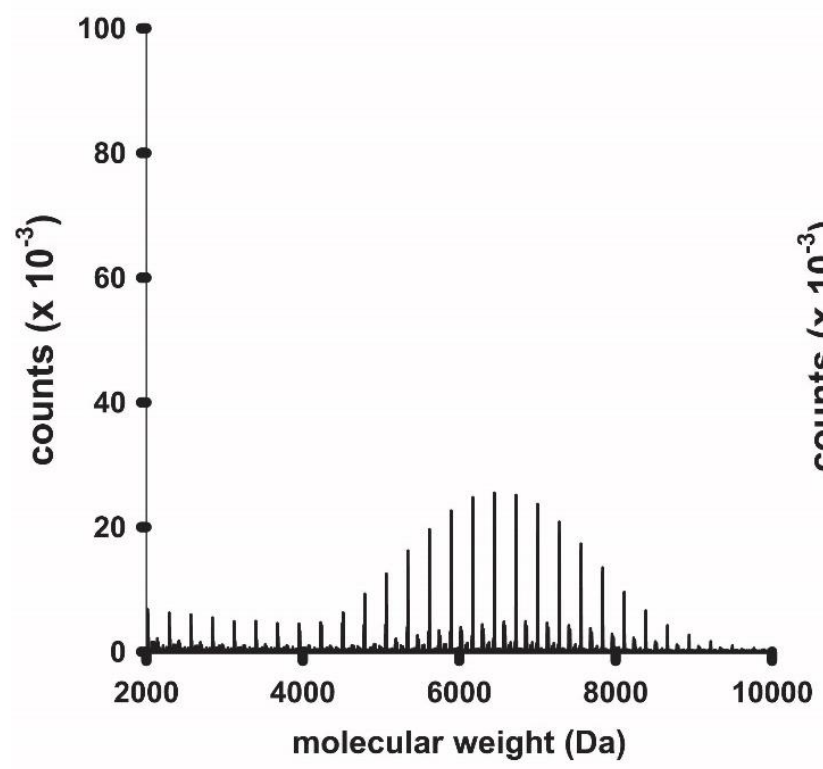

b.

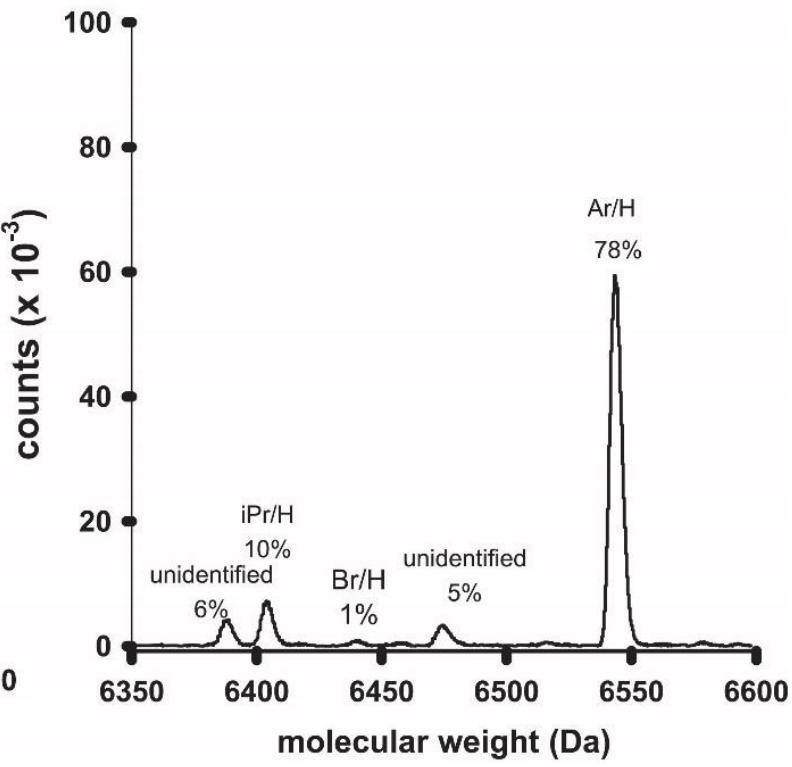

Figure S31. a. Full MALDI-TOF MS spectrum of polyphenylene initiated with precatalyst $\mathbf{2 f}$, and b., MALDI-TOF MS spectrum at 23 repeat units.

a.

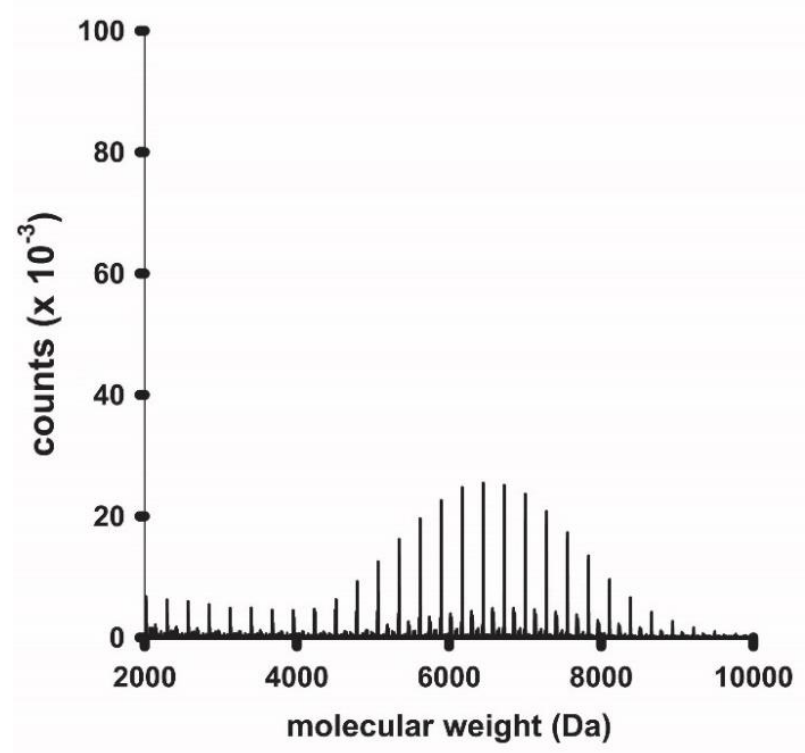

b.

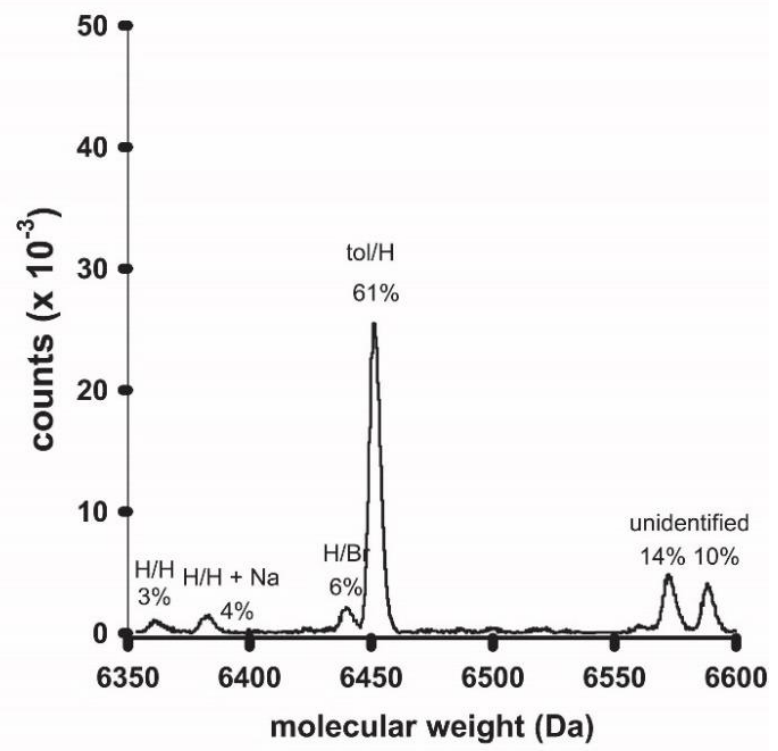

Figure S32. a. Full MALDI-TOF MS spectrum of polyphenylene initiated with $\mathrm{Ni}(\mathrm{dppe}) \mathrm{tolBr}$, and b., MALDI-TOF MS spectrum at 23 repeat units. 
a.

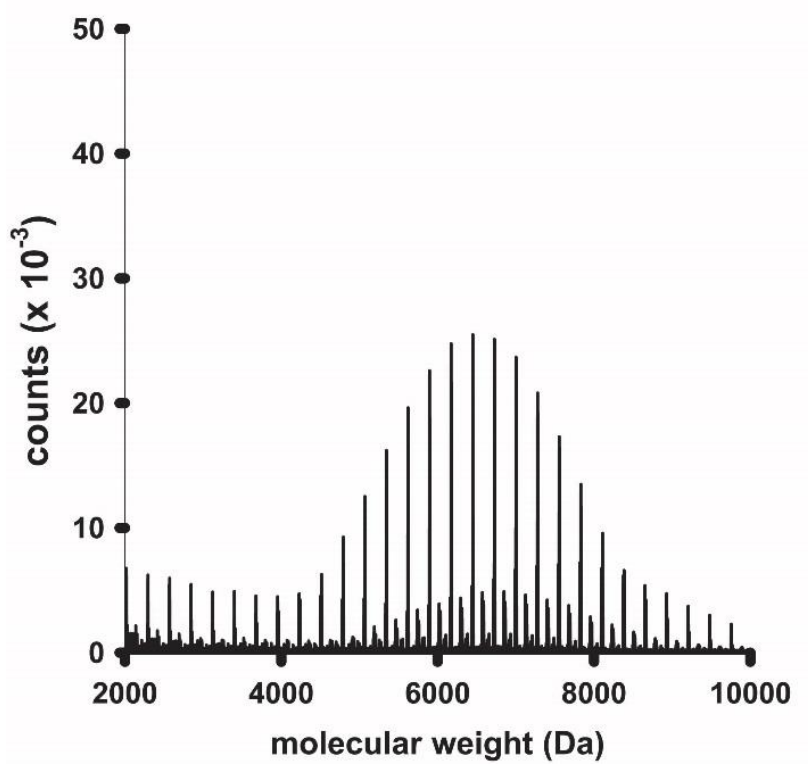

b.

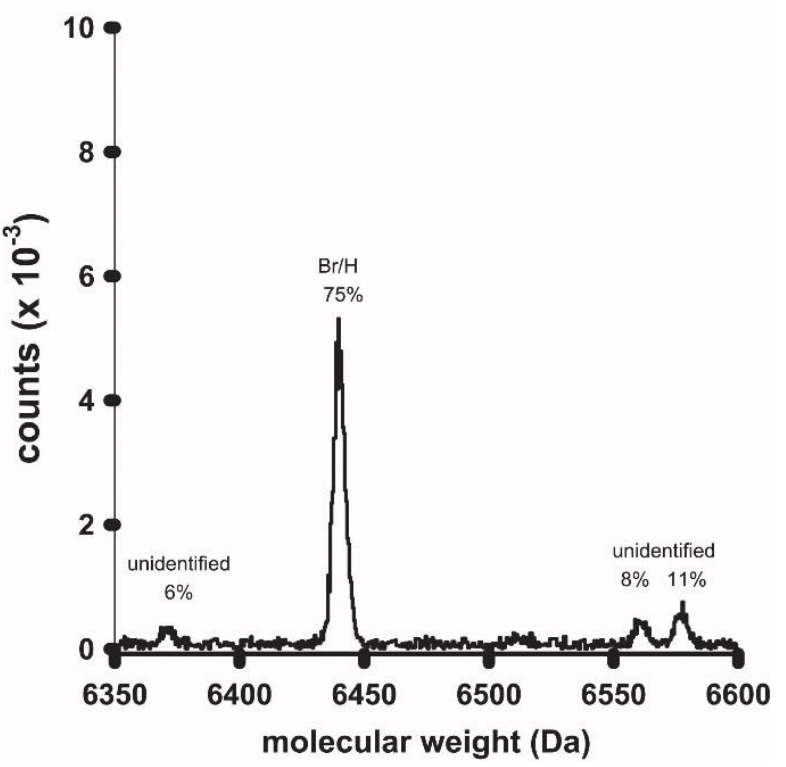

Figure S33. a. Full MALDI-TOF MS spectrum of polyphenylene initiated with $\mathrm{Ni}(\mathrm{dppe}) \mathrm{Cl}_{2}$, and b., MALDI-TOF MS spectrum at 23 repeat units. 


\section{$\underline{\text { X. Computational Data }}$}

Computations were performed with the BP86 DFT functional ${ }^{5}$ paired with the $6-311+\mathrm{G}(\mathrm{d})$ basis set $^{6}$ was used for all non-metal atoms and the SDB-cc-pVTZ basis set with the small core, fully relativistic effective core potential ${ }^{7}$ was used for $\mathrm{Ni}$. All computations were performed using Gaussian09.

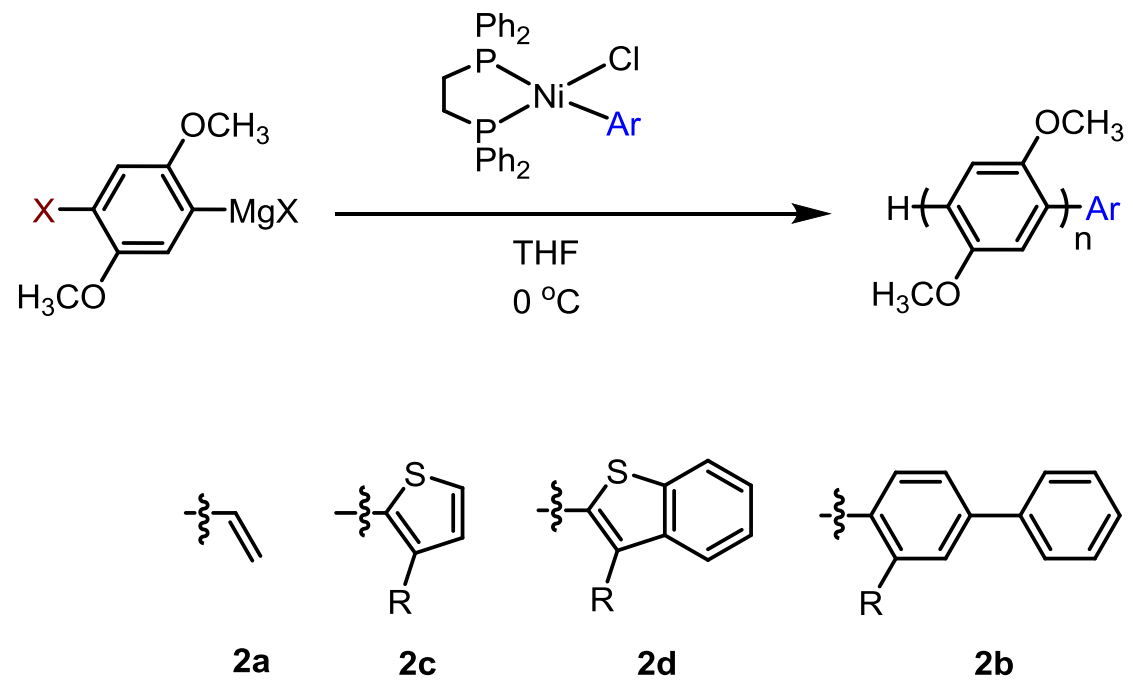




\begin{tabular}{|c|c|c|c|c|c|c|c|}
\hline $\mathrm{Ar}$ & $\mathbf{x}$ & $\mathbf{R}$ & $E$ (Reactant) & $\mathbf{G ( R e a c t a n t )}$ & $E(T S)$ & $\mathrm{G}(\mathrm{TS})$ & $\Delta q$ \\
\hline 1 & $\mathrm{Br}$ & -- & $\begin{array}{c}- \\
4971.905404\end{array}$ & $\begin{array}{c}- \\
4971.387898\end{array}$ & $\begin{array}{c}- \\
971.894311\end{array}$ & $\begin{array}{c}- \\
4971.377567\end{array}$ & -- \\
\hline 2 & $\mathrm{Br}$ & $\mathrm{CH}_{3}$ & $\begin{array}{c}- \\
5485.725328\end{array}$ & $\begin{array}{c}- \\
5485.169361\end{array}$ & -5485.70677 & $\begin{array}{c}- \\
5485.151145\end{array}$ & -- \\
\hline 3 & $\mathrm{Br}$ & $\mathrm{CH}_{3}$ & $\begin{array}{c}- \\
5639.408931\end{array}$ & $\begin{array}{c}- \\
5638.810395\end{array}$ & 5639.389398 & $\begin{array}{c}- \\
5638.791431\end{array}$ & -- \\
\hline 4 & $\mathrm{Br}$ & $\mathrm{CH}_{3}$ & $\begin{array}{c}- \\
5396.017061\end{array}$ & 5395.356236 & -5395.99755 & $\begin{array}{c}- \\
5395.338129\end{array}$ & 0.244 \\
\hline 5 & $\mathrm{Br}$ & $\mathrm{OCH}_{3}$ & $\begin{array}{c}- \\
5471.255943\end{array}$ & $\begin{array}{c}- \\
5470.591858\end{array}$ & 5471.238104 & $\begin{array}{c}- \\
5470.575208\end{array}$ & .247 \\
\hline 5 & $\mathrm{Br}$ & $\mathrm{OCH}_{2} \mathrm{CH}_{3}$ & $\begin{array}{c}- \\
5510.578995\end{array}$ & $\begin{array}{c}- \\
5509.889101\end{array}$ & $\begin{array}{c}- \\
5510.561344\end{array}$ & $\begin{array}{c}- \\
5509.872064\end{array}$ & 0.249 \\
\hline 5 & $\mathrm{Br}$ & $\mathrm{OCH}_{2} \mathrm{CF}_{3}$ & $\begin{array}{c}- \\
5808.410915\end{array}$ & -5807.74857 & $\begin{array}{c}- \\
5808.391911\end{array}$ & $\begin{array}{c}- \\
5807.728671\end{array}$ & 0.259 \\
\hline 1 & $\mathrm{Cl}$ & $\mathrm{CH}_{3}$ & $\begin{array}{c}- \\
2857.765163\end{array}$ & $\begin{array}{c}- \\
2857.245191\end{array}$ & $\begin{array}{c}- \\
2857.754257\end{array}$ & $\begin{array}{c}- \\
2857.234281\end{array}$ & -- \\
\hline 2 & $\mathrm{Cl}$ & $\mathrm{CH}_{3}$ & $\begin{array}{c}- \\
3371.584513\end{array}$ & -3371.02894 & 3371.567536 & 3371.011248 & -- \\
\hline 3 & $\mathrm{Cl}$ & $\mathrm{CH}_{3}$ & $\begin{array}{c}- \\
3525.268913\end{array}$ & -3524.66836 & 3525.249288 & $\begin{array}{c}- \\
3524.647572\end{array}$ & -- \\
\hline 4 & $\mathrm{Cl}$ & $\mathrm{CH}_{3}$ & $\begin{array}{c}- \\
3281.876847 \\
\end{array}$ & 3281.214682 & 3281.856381 & $\begin{array}{c}- \\
3281.193542 \\
\end{array}$ & -- \\
\hline
\end{tabular}

Table S18. Absolute electronic energies (E) and free energies (G), in hartrees, for reactants and transition states (TS), along with the corresponding change in NPA charges for select species $(\Delta q)$. 


\section{Optimized Cartesian Coordinates for lowest-lying conformer of each reactant and transition state}

\begin{tabular}{|c|c|c|c|}
\hline \multicolumn{4}{|c|}{$\mathrm{X}=\mathrm{Cl}$} \\
\hline \multicolumn{4}{|c|}{77} \\
\hline \multicolumn{4}{|c|}{$\mathrm{Ar}=$ ethene reactant } \\
\hline $\mathrm{Ni}$ & -0.3717520 & -0.1247440 & -0.5619730 \\
\hline $\mathrm{P}$ & -2.4608960 & -0.0748170 & 0.1254800 \\
\hline $\mathrm{P}$ & 0.2323010 & 0.3811650 & 1.5149420 \\
\hline C & -2.5068100 & 0.5446130 & 1.9059270 \\
\hline C & -3.1925730 & -1.7686380 & 0.2903650 \\
\hline C & -3.7765050 & 0.8914110 & -0.7373430 \\
\hline C & 1.4240490 & -0.3381900 & -1.2175490 \\
\hline C & -1.2473440 & 0.0423040 & 2.6259580 \\
\hline C & 0.4778840 & 2.2060570 & 1.7538110 \\
\hline C & 1.6730190 & -0.3502320 & 2.4046390 \\
\hline $\mathrm{H}$ & -3.4284160 & 0.2168710 & 2.4140570 \\
\hline $\mathrm{H}$ & -2.5091560 & 1.6467730 & 1.8854750 \\
\hline C & -4.5212590 & -1.9644210 & 0.7186240 \\
\hline C & -2.3794570 & -2.8863900 & 0.0257790 \\
\hline C & -4.4473260 & 0.3135970 & -1.8351490 \\
\hline C & -4.0511780 & 2.2331850 & -0.4050310 \\
\hline C & 2.0413440 & -1.6008350 & -1.0999080 \\
\hline C & 2.1809610 & 0.6996370 & -1.7891900 \\
\hline $\mathrm{H}$ & -1.1305090 & 0.5169470 & 3.6147330 \\
\hline $\mathrm{H}$ & -1.3039120 & -1.0500770 & 2.7731220 \\
\hline C & 1.0092270 & 2.7448780 & 2.9419830 \\
\hline C & 0.0813180 & 3.0776250 & 0.7217190 \\
\hline C & 2.9603680 & -0.1415270 & 1.8654430 \\
\hline C & 1.5389180 & -1.1276460 & 3.5715300 \\
\hline C & -5.0271820 & -3.2598110 & 0.8806390 \\
\hline $\mathrm{H}$ & -5.1699860 & -1.1025530 & 0.9092550 \\
\hline C & -2.8907760 & -4.1828730 & 0.1903130 \\
\hline $\mathrm{H}$ & -1.3484300 & -2.7328730 & -0.3125970 \\
\hline C & -5.3929770 & 1.0512150 & -2.5583800 \\
\hline $\mathrm{H}$ & -4.2304320 & -0.7181880 & -2.1235280 \\
\hline C & -4.9969560 & 2.9690080 & -1.1321220 \\
\hline $\mathrm{H}$ & -3.5302030 & 2.7215540 & 0.4239340 \\
\hline C & 3.3660720 & -1.8090780 & -1.5181980 \\
\hline $\mathrm{O}$ & 1.2616950 & -2.6118190 & -0.5406790 \\
\hline C & 3.5145380 & 0.5260060 & -2.2157570 \\
\hline $\mathrm{H}$ & 1.7121390 & 1.6783040 & -1.9230120 \\
\hline
\end{tabular}




$\begin{array}{lrrr}\mathrm{C} & 1.1299470 & 4.1318260 & 3.0963200 \\ \mathrm{H} & 1.3450510 & 2.0777500 & 3.7429940 \\ \mathrm{C} & 0.2001080 & 4.4662950 & 0.8789870 \\ \mathrm{H} & -0.3119800 & 2.6545960 & -0.2106130 \\ \mathrm{C} & 4.0862370 & -0.6899220 & 2.4909300 \\ \mathrm{H} & 3.0814240 & 0.4443630 & 0.9492770 \\ \mathrm{C} & 2.6697110 & -1.6782270 & 4.1924100 \\ \mathrm{H} & 0.5535270 & -1.3096960 & 4.0102860 \\ \mathrm{C} & -4.2116310 & -4.3713210 & 0.6168110 \\ \mathrm{H} & -6.0623390 & -3.4032490 & 1.2080190 \\ \mathrm{H} & -2.2552580 & -5.0485170 & -0.0234420 \\ \mathrm{C} & -5.6736580 & 2.3788790 & -2.2080740 \\ \mathrm{H} & -5.9074490 & 0.5856080 & -3.4052990 \\ \mathrm{H} & -5.2046240 & 4.0075280 & -0.8537550 \\ \mathrm{C} & 4.0941740 & -0.7462360 & -2.0656220 \\ \mathrm{H} & 3.8592700 & -2.7796450 & -1.4314920 \\ \mathrm{C} & 1.8645280 & -3.8950440 & -0.3915330 \\ \mathrm{O} & 4.2959720 & 1.5118420 & -2.7730380 \\ \mathrm{C} & 0.7238830 & 4.9944300 & 2.0665810 \\ \mathrm{H} & 1.5490890 & 4.5414890 & 4.0213990 \\ \mathrm{H} & -0.1082580 & 5.1350430 & 0.0685050 \\ \mathrm{C} & 3.9449750 & -1.4582610 & 3.6557200 \\ \mathrm{H} & 5.0775500 & -0.5207260 & 2.0589560 \\ \mathrm{H} & 2.5502530 & -2.2776780 & 5.1011560 \\ \mathrm{H} & -4.6101230 & -5.3838390 & 0.7399690 \\ \mathrm{H} & -6.4130320 & 2.9538040 & -2.7750870 \\ \mathrm{Cl} & 5.7589100 & -1.0211260 & -2.5788870 \\ \mathrm{H} & 2.7534630 & -3.8546100 & 0.2645080 \\ \mathrm{H} & 1.1032190 & -4.5351670 & 0.0757900 \\ \mathrm{H} & 2.1518080 & -4.3271580 & -1.3682840 \\ \mathrm{C} & 3.6943420 & 2.7879450 & -2.9801380 \\ \mathrm{H} & 0.8239580 & 6.0779870 & 2.1885050 \\ \mathrm{H} & 4.8272830 & -1.8873640 & 4.1418160 \\ \mathrm{H} & 2.8222900 & 2.7209080 & -3.6554420 \\ \mathrm{H} & 4.4721380 & 3.4060700 & -3.4486310 \\ \mathrm{H} & 3.3836070 & 3.2521470 & -2.0260830 \\ \mathrm{C} & -0.8560620 & -0.5171180 & -2.3664630 \\ \mathrm{C} & -1.3775200 & 0.3173020 & -3.2864080 \\ \mathrm{H} & -0.6284160 & -1.5485890 & -2.6850140 \\ \mathrm{H} & -1.5716080 & -0.0097950 & -4.3193350 \\ \mathrm{H} & -1.6250740 & 1.3658620 & -3.0761580 \\ 77 & & & \\ \mathrm{Ar}= & \mathrm{ethene} \mathrm{TS} & & \\ & & & \end{array}$




\begin{tabular}{|c|c|c|c|}
\hline $\mathrm{C}$ & 2.1169210 & 0.5624360 & -1.9239610 \\
\hline C & 3.2365090 & -1.9632100 & -1.5444210 \\
\hline C & 1.2585590 & -0.4967710 & -1.5229080 \\
\hline r & 3.7090880 & -2.9357440 & -1.3926880 \\
\hline 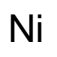 & -0.3754280 & -0.1237090 & -0.5450910 \\
\hline$P$ & -2.4853280 & 0.0037950 & 0.1005390 \\
\hline$P$ & 0.2458910 & 0.4994290 & 1.4850680 \\
\hline C & -2.4994380 & 0.8066420 & 1.8074300 \\
\hline C & -3.2675380 & -1.6442170 & 0.4558170 \\
\hline C & -3.8113760 & 0.8979190 & -0.8241600 \\
\hline C & -1.2673620 & 0.3306590 & 2.5934140 \\
\hline C & 1.6169340 & -0.2795430 & 2.4457780 \\
\hline $\mathrm{C}$ & 0.6157050 & 2.3158180 & 1.6347200 \\
\hline $\mathrm{H}$ & -2.4479130 & 1.8991970 & 3170 \\
\hline $\mathrm{H}$ & -3.4318700 & 0.5814610 & 2.35 \\
\hline C & -4.6425190 & -1.7854410 & 0.7283100 \\
\hline C & -2.4392800 & -2.7825940 & 0.4858490 \\
\hline C & -4.6241940 & 1.9039420 & -0.2636530 \\
\hline C & -3.9800700 & 0.56 & -2.18 \\
\hline $\mathrm{H}$ & -1.3694270 & -0.7391210 & 2.84 \\
\hline $\mathrm{H}$ & -1.1510370 & 0.8966180 & 3.5331800 \\
\hline $\mathrm{C}$ & 2.8882960 & -0.3321190 & 1.8344280 \\
\hline C & 1.4504680 & -0.85 & 3.72 \\
\hline C & 1.3091890 & 2.8670630 & 2.7298180 \\
\hline C & 0.1527030 & 3.1734550 & 0.617 \\
\hline C & -5.1771720 & -3.0430460 & 1.03 \\
\hline $\mathrm{H}$ & $-5.301 \varepsilon$ & -0.9 & 80 \\
\hline C & -2.9767730 & 94070 & 0.80 \\
\hline $\mathrm{H}$ & -1.3740830 & -2.6773650 & 0.2472310 \\
\hline C & -5.5918630 & 2.5543450 & -1.0432640 \\
\hline $\mathrm{H}$ & -4.5155280 & 2.1848420 & 0.7881850 \\
\hline C & -4.9519390 & 1.2135250 & -2.9589520 \\
\hline $\mathrm{H}$ & -3.3303790 & -0.1851660 & -2.6432590 \\
\hline C & 3.9678810 & -0.9333820 & 2.4917770 \\
\hline $\mathrm{H}$ & 3.0324640 & 0.0948180 & 0.8364200 \\
\hline C & 2.5327180 & -1.4666680 & 4.3720960 \\
\hline $\mathrm{H}$ & 0.4767130 & -0.8326520 & 4.2185840 \\
\hline $\mathrm{C}$ & 1.5259190 & 4.2493040 & 2.8078690 \\
\hline $\mathrm{H}$ & 1.6932680 & 2.2118400 & 3.5186270 \\
\hline C & 0.3617760 & 4.5573950 & 0.7012590 \\
\hline $\mathrm{H}$ & -0.3682300 & 2.7432930 & -0.2471350 \\
\hline C & -4.3442880 & -4.1715830 & 1.0771240 \\
\hline $\mathrm{H}$ & -6.2486600 & -3.1440730 & 1.2394480 \\
\hline
\end{tabular}




$\begin{array}{lrrr}\mathrm{H} & -2.3263320 & -4.9202400 & 0.8239130 \\ \mathrm{C} & -5.7612080 & 2.2082070 & -2.3906450 \\ \mathrm{H} & -6.2185620 & 3.3311530 & -0.5921500 \\ \mathrm{H} & -5.0711950 & 0.9452050 & -4.0139230 \\ \mathrm{C} & 3.7935380 & -1.5028700 & 3.7620880 \\ \mathrm{H} & 4.9472900 & -0.9628670 & 2.0037550 \\ \mathrm{H} & 2.3880750 & -1.9099420 & 5.3632120 \\ \mathrm{C} & 1.0499720 & 5.0971870 & 1.7966320 \\ \mathrm{H} & 2.0718410 & 4.6661370 & 3.6609980 \\ \mathrm{H} & -0.0067560 & 5.2136190 & -0.0943840 \\ \mathrm{H} & -4.7642610 & -5.1542270 & 1.3163440 \\ \mathrm{H} & -6.5185690 & 2.7154320 & -2.9973090 \\ \mathrm{H} & 4.6380060 & -1.9768120 & 4.2731860 \\ \mathrm{H} & 1.2215080 & 6.1768160 & 1.8601030 \\ \mathrm{C} & -0.3789970 & -0.6407240 & -2.4039810 \\ \mathrm{H} & 1.6703810 & 1.5429110 & -2.1069780 \\ \mathrm{C} & -0.6524470 & 0.1483990 & -3.4807690 \\ \mathrm{C} & 3.4901640 & 0.3944540 & -2.1318620 \\ \mathrm{C} & 4.3569410 & 1.3910640 & -2.5096810 \\ \mathrm{C} & -3.0185050 & -1.0304530 & -1.5642490 \\ \mathrm{C} & -3.7433400 & 0.0521720 & 1.0306460 \\ \mathrm{C} & 3.8031160 & 2.6821250 & -2.7594350 \\ \mathrm{H} & 3.0642280 & 2.6524890 & -3.5806830 \\ \mathrm{H} & 4.6518740 & 3.3130440 & -3.0551450 \\ \mathrm{H} & 3.3300350 & 3.1034130 & -1.8539870 \\ \mathrm{C} & 1.8639770 & -1.7687930 & -1.3247240 \\ \mathrm{O} & 1.0236030 & -2.7837920 & -0.8907440 \\ \mathrm{C} & 1.5683050 & -4.1004310 & -0.8089330 \\ \mathrm{H} & 2.3574730 & -4.1672750 & -0.0379920 \\ \mathrm{H} & 0.7324380 & -4.7545250 & -0.5258580 \\ \mathrm{H} & 1.9757350 & -4.4314410 & -1.7816500 \\ \mathrm{Cl} & 4.0430420 & -0.8931460 & -1.9418370 \\ \mathrm{H} & -0.5655960 & 1.0147700 & -0.2223310\end{array}$




\begin{tabular}{|c|c|c|c|}
\hline $\mathrm{C}$ & -0.8621150 & -3.0279020 & 0.1872730 \\
\hline C & 1.0280430 & -2.0460710 & 2.1443360 \\
\hline C & 1.9484040 & -2.4900070 & -0.5670430 \\
\hline $\mathrm{H}$ & -3.0181920 & -3.0372040 & 0.6004270 \\
\hline $\mathrm{H}$ & -2.0112470 & -2.3433780 & 1.9031860 \\
\hline C & -4.3458830 & -1.4702100 & -1.7359880 \\
\hline C & -2.1797400 & -0.9013160 & -2.6872170 \\
\hline C & -4.2399010 & 1.2980550 & 0.5900770 \\
\hline C & -4.3201570 & -0.5550190 & 2.1633360 \\
\hline C & 1.9943360 & 1.0350590 & -1.5191400 \\
\hline C & 2.2140850 & 1.5470940 & 0.8236130 \\
\hline $\mathrm{H}$ & -0.5989500 & -3.9926060 & 0.6517480 \\
\hline $\mathrm{H}$ & -1.0201540 & -3.1963250 & -0.8916740 \\
\hline C & 1.8070220 & -3.1506670 & 2.5417330 \\
\hline C & 0.5612880 & -1.1489030 & 3.1231280 \\
\hline C & 3.2172420 & -1.8896580 & -0.4213860 \\
\hline C & 1.8057560 & -3.5823170 & -1.4447200 \\
\hline C & -4.8234860 & -1.7865190 & -3.0137630 \\
\hline $\mathrm{H}$ & -5.0135160 & -1.5499880 & -0.8714020 \\
\hline C & -2.6624410 & -1.2225100 & -3.9646630 \\
\hline $\mathrm{H}$ & -1.1552530 & -0.5333320 & -2.5581340 \\
\hline C & -5.2996630 & 1.91 & 1.2683270 \\
\hline $\mathrm{H}$ & -3.7954410 & 1.7896880 & -0.2801450 \\
\hline C & -5.3796090 & 0.0667730 & 2.8399930 \\
\hline $\mathrm{H}$ & -3.9545210 & -1.5197650 & 2.5271990 \\
\hline C & 3.2713 & 1.5680870 & -1.7566890 \\
\hline $\mathrm{O}$ & 1.2075630 & 0.4862030 & -2.5261250 \\
\hline C & 3.5040520 & 2.0824140 & 0.6186260 \\
\hline $\mathrm{H}$ & 1.7992520 & 1.5563890 & 1.8348650 \\
\hline C & 2.1048040 & -3.3543420 & 3.8952360 \\
\hline $\mathrm{H}$ & 2.1938940 & -3.8463320 & 1.7899940 \\
\hline C & 0.8558660 & -1.3570310 & 4.4782250 \\
\hline $\mathrm{H}$ & -0.0284800 & -0.2786510 & 2.8136070 \\
\hline C & 4.3176920 & -2.3822520 & -1.1328530 \\
\hline $\mathrm{H}$ & 3.3445750 & -1.0325430 & 0.2464000 \\
\hline C & 2.9110850 & -4.0707490 & -2.1562720 \\
\hline $\mathrm{H}$ & 0.8348490 & -4.0669220 & -1.5811490 \\
\hline C & -3.9812150 & -1.6652590 & -4.1295470 \\
\hline $\mathrm{H}$ & -5.8583170 & -2.1217190 & -3.1402960 \\
\hline $\mathrm{H}$ & -2.0083910 & -1.1140230 & -4.8359930 \\
\hline C & -5.8716080 & 1.3001500 & 2.3934320 \\
\hline $\mathrm{H}$ & -5.6745250 & 2.8780170 & 0.9163000 \\
\hline $\mathrm{H}$ & -5.8218170 & -0.4187070 & 3.7163340 \\
\hline
\end{tabular}




\begin{tabular}{|c|c|c|c|}
\hline $\mathrm{C}$ & 4.0175330 & 2.0825390 & -0.6900840 \\
\hline $\mathrm{H}$ & 3.7133100 & 1.5947260 & -2.7549930 \\
\hline C & 1.6873680 & 0.5979080 & -3.8646370 \\
\hline O & 4.3019020 & 2.6082910 & 1.6079320 \\
\hline C & 1.6283880 & -2.4599470 & 4.8655890 \\
\hline $\mathrm{H}$ & 2.7158420 & -4.2127910 & 4.1932810 \\
\hline $\mathrm{H}$ & 0.4872940 & -0.6515940 & 5.2301820 \\
\hline C & 4.1688450 & -3.4736410 & -2.0006190 \\
\hline $\mathrm{H}$ & 5.2944890 & -1.9040210 & -1.0104830 \\
\hline $\mathrm{H}$ & 2.7854950 & -4.9236060 & -2.8315950 \\
\hline $\mathrm{H}$ & -4.3579460 & -1.9080020 & -5.1286600 \\
\hline $\mathrm{H}$ & -6.6989890 & 1.7849520 & 2.9219610 \\
\hline $\mathrm{Cl}$ & 5.6229360 & 2.7398220 & -1.0045920 \\
\hline $\mathrm{H}$ & 2.6319720 & 0.0414080 & -4.0080150 \\
\hline $\mathrm{H}$ & 0.9106690 & 0.1554320 & -4.5034340 \\
\hline $\mathrm{H}$ & 1.8346020 & 1.6545820 & -4.1527810 \\
\hline $\mathrm{C}$ & 3.7667730 & 2.6569080 & 2.9285180 \\
\hline $\mathrm{H}$ & 1.8652560 & -2.6205590 & 5.9224170 \\
\hline $\mathrm{H}$ & 5.0314510 & -3.85 & -2.5558280 \\
\hline $\mathrm{H}$ & 2.8488710 & 3.2706090 & 2.9718070 \\
\hline $\mathrm{H}$ & 4.5469940 & 3.1247040 & 3.5439850 \\
\hline $\mathrm{H}$ & 3.5502200 & 1.6454500 & 3.3185460 \\
\hline C & -0.9881350 & 2.0 & -0.1858140 \\
\hline C & -1.3297210 & 2.9718270 & 0.7738920 \\
\hline S & -1.3005770 & 2.6809650 & -1.7900390 \\
\hline C & -1.8426990 & 4.1951190 & 0.2136300 \\
\hline $\mathrm{C}$ & -1.8997 & 4.1 & -1.1590660 \\
\hline $\mathrm{H}$ & -2.1591450 & 5040 & 0.8245540 \\
\hline $\mathrm{H}$ & -2.2420860 & 4.9851540 & -1.8298470 \\
\hline C & -1.1785860 & 2.7710060 & 2.2625720 \\
\hline $\mathrm{H}$ & -0.3473160 & 3.3700430 & 2.6790850 \\
\hline $\mathrm{H}$ & -2.0917590 & 3.0614880 & 2.8117860 \\
\hline $\mathrm{H}$ & -0.9744440 & 1.71 & 2.4978090 \\
\hline \multicolumn{4}{|c|}{83} \\
\hline \multicolumn{4}{|c|}{$\mathrm{Ar}=$ methylthiophene TS } \\
\hline C & -2.0746310 & -1.6003900 & 0.9866470 \\
\hline C & -3.1522640 & -1.8308650 & -1.5767460 \\
\hline C & -1.1993950 & -1.4114320 & -0.1244420 \\
\hline $\mathrm{H}$ & -3.6067350 & -1.9032290 & -2.5670780 \\
\hline $\mathrm{Ni}$ & 0.3285170 & -0.2120080 & 0.0069950 \\
\hline$P$ & 2.3678330 & 0.6754150 & 0.0632310 \\
\hline$P$ & -0.5158030 & 1.8341670 & 0.1299900 \\
\hline C & 2.1591860 & 2.4842570 & 0.5462510 \\
\hline
\end{tabular}




$\begin{array}{lrrr}\text { C } & 3.1729690 & 0.8356250 & -1.6032530 \\ \text { C } & 3.7401980 & 0.0637940 & 1.1350800 \\ \text { C } & 0.9057460 & 3.0376250 & -0.1524640 \\ \text { C } & -1.8873130 & 2.4516530 & -0.9393310 \\ \text { C } & -1.0729020 & 2.3268930 & 1.8339780 \\ \text { H } & 2.0276270 & 2.5205630 & 1.6419530 \\ \text { H } & 3.0521740 & 3.0787510 & 0.2896930 \\ \text { C } & 4.5287450 & 1.1861770 & -1.7557800 \\ \mathrm{C} & 2.3810880 & 0.6342360 & -2.7499200 \\ \text { C } & 4.4362770 & 0.8691780 & 2.0588670 \\ \text { C } & 4.0659220 & -1.3068730 & 1.0426360 \\ \text { H } & 1.0782390 & 3.0957870 & -1.2414610 \\ \text { H } & 0.6584150 & 4.0497440 & 0.2095120 \\ \mathrm{C} & -3.1079180 & 1.7430440 & -0.8987440 \\ \mathrm{C} & -1.7647510 & 3.5459000 & -1.8183810 \\ \mathrm{C} & -1.9600450 & 3.3960100 & 2.0660050 \\ \mathrm{C} & -0.5516870 & 1.6219420 & 2.9368310 \\ \mathrm{C} & 5.0792050 & 1.3419580 & -3.0343880 \\ \mathrm{H} & 5.1606970 & 1.3254810 & -0.8721150 \\ \mathrm{C} & 2.9331520 & 0.7988510 & -4.0286460 \\ \mathrm{H} & 1.3338840 & 0.3324470 & -2.6332400 \\ \mathrm{C} & 5.4420860 & 0.3187960 & 2.8670050 \\ \mathrm{H} & 4.2042350 & 1.9345270 & 2.1531340 \\ \mathrm{C} & 5.0774700 & -1.8489610 & 1.8438950 \\ \mathrm{H} & 3.5195590 & -1.9541760 & 0.3488060 \\ \mathrm{C} & -4.1836250 & 2.1355270 & -1.7035960 \\ \mathrm{H} & -3.2183790 & 0.8792910 & -0.2349250 \\ \mathrm{C} & -2.8419490 & 3.9297310 & -2.6306950 \\ \mathrm{H} & -0.8311430 & 4.1134640 & -1.8737100 \\ \mathrm{C} & -2.3103540 & 3.7549580 & 3.3745370 \\ \mathrm{H} & -2.3870100 & 3.9432570 & 1.2194710 \\ \mathrm{C} & -0.8944850 & 1.9882230 & 4.2460410 \\ \mathrm{H} & 0.1230870 & 0.7763500 & 2.7586690 \\ \mathrm{C} & 4.2814650 & 1.1519690 & -4.1729490 \\ \mathrm{H} & 6.1359310 & 1.6088420 & -3.1428660 \\ \mathrm{H} & 2.3102800 & 0.6397800 & -4.9152020 \\ \mathrm{C} & 5.7677730 & -1.0397620 & 2.7588750 \\ \mathrm{H} & 5.9754820 & 0.9576100 & 3.5791240 \\ \mathrm{H} & 5.3216770 & -2.9128210 & 1.7572520 \\ \mathrm{C} & -4.0543240 & 3.2295390 & -2.5722950 \\ \mathrm{H} & -5.1240440 & 1.5774360 & -1.6548490 \\ \mathrm{H} & -2.7324370 & 4.7851530 & -3.3059090 \\ \mathrm{C} & -1.7761040 & 3.0554350 & 4.4667350\end{array}$




$\begin{array}{lllr}\mathrm{H} & -3.0052060 & 4.5848350 & 3.5418250 \\ \mathrm{H} & -0.4781730 & 1.4341640 & 5.0940630 \\ \mathrm{H} & 4.7142890 & 1.2720540 & -5.1716630 \\ \mathrm{H} & 6.5546880 & -1.4681370 & 3.3883060 \\ \mathrm{H} & -4.8954890 & 3.5332560 & -3.2040490 \\ \mathrm{H} & -2.0514870 & 3.3387500 & 5.4879410 \\ \mathrm{H} & -1.6701820 & -1.4877660 & 1.9915230 \\ \mathrm{C} & -3.4353300 & -1.9088180 & 0.8442360 \\ \mathrm{O} & -4.3096640 & -2.0829790 & 1.8904980 \\ \mathrm{C} & -3.7945030 & -1.9424350 & 3.2129950 \\ \mathrm{H} & -3.0094600 & -2.6911110 & 3.4234660 \\ \mathrm{H} & -4.6492850 & -2.1155720 & 3.8803800 \\ \mathrm{H} & -3.3922560 & -0.9279460 & 3.3867210 \\ \mathrm{C} & -1.8060140 & -1.4939010 & -1.4166830 \\ \mathrm{O} & -0.9720720 & -1.2037430 & -2.4808740 \\ \mathrm{C} & -1.4285910 & -1.5373970 & -3.7935740 \\ \mathrm{H} & -2.2741800 & -0.8963500 & -4.1011960 \\ \mathrm{H} & -0.5767080 & -1.3575340 & -4.4628710 \\ \mathrm{H} & -1.7246260 & -2.5994110 & -3.8546860 \\ \mathrm{C} & -3.9650980 & -2.0439290 & -0.4557760 \\ \mathrm{Cl} & -5.6586180 & -2.4602940 & -0.6838490 \\ \mathrm{C} & 0.4763590 & -2.1376810 & 0.0027140 \\ \mathrm{C} & 1.7926900 & -4.2404570 & -0.6317170 \\ \mathrm{C} & 1.5848640 & -4.1143060 & 0.7234590 \\ \mathrm{H} & 2.2981400 & -5.0424170 & -1.1705430 \\ \mathrm{H} & 1.9432590 & -4.8475350 & 1.4535920 \\ \mathrm{C} & 0.8605890 & -2.9434950 & 1.1002260 \\ \mathrm{C} & 0.5527880 & -2.6544880 & 2.5468870 \\ \mathrm{H} & -0.4053780 & -3.1097040 & 2.8639530 \\ \mathrm{H} & 1.3359480 & -3.0694010 & 3.2027730 \\ \mathrm{H} & 0.4918970 & -1.5737440 & 2.7519360 \\ \mathrm{~S} & 1.0875270 & -2.9056390 & -1.4981600 \\ 89 & & & \\ \mathrm{Ar}= & \mathrm{methylbenzothiophene} \mathrm{reactant} & \\ \mathrm{Ni} & -0.1011150 & -0.1793170 & -0.0492820 \\ \mathrm{P} & -1.6962240 & -1.7388940 & 0.0781410 \\ \mathrm{P} & 1.3238790 & -1.7454780 & 0.6232950 \\ \mathrm{C} & -0.9834890 & -3.2299350 & 0.9765840 \\ \mathrm{C} & -2.0742150 & -2.4579910 & -1.5891630 \\ \mathrm{C} & -3.3645250 & -1.4883220 & 0.8191570 \\ \mathrm{C} & 1.3142620 & 1.0804740 & -0.3865410 \\ \mathrm{C} & 0.4685200 & -3.4157710 & 0.5159230 \\ \mathrm{C} & 1.6108020 & -1.5906000 & 2.4498460\end{array}$




\begin{tabular}{|c|c|c|c|}
\hline $\mathrm{C}$ & 3.0202850 & -2.0289730 & -0.0400070 \\
\hline $\mathrm{H}$ & -1.5874550 & -4.1329270 & 0.7880190 \\
\hline & -1.0106940 & -3.0163240 & 2.0587850 \\
\hline C & -3.1789160 & -3.3093700 & -1.7897040 \\
\hline C & -1.2069480 & -2.1841470 & -2.6637660 \\
\hline C & -4.2020070 & -0.5085130 & 0.2456670 \\
\hline C & -3.8202490 & -2.2082120 & 1.9401090 \\
\hline C & 2.0227280 & 0.9780460 & -1.6021390 \\
\hline C & 1.7125290 & 2.0837170 & 0.5134120 \\
\hline $\mathrm{H}$ & 0.9940620 & -4.1737920 & 1.1201350 \\
\hline $\mathrm{H}$ & 0.4902830 & -3.7392800 & -0.5388110 \\
\hline C & 2.5866280 & -2.3619180 & 3.1120870 \\
\hline C & 0.79 & -0.7192190 & 3.1990270 \\
\hline C & 3.9898550 & -1.0216300 & 0.1501250 \\
\hline C & 3.3739170 & -3.1938260 & -0.7485230 \\
\hline C & -3.4069700 & -3.8843970 & -3.0460730 \\
\hline $\mathrm{H}$ & -3.87 & -3.510 & -0.9666040 \\
\hline C & -1.4390020 & -2.7648910 & -3.9196950 \\
\hline $\mathrm{H}$ & -0.3599370 & -1.5041470 & -2.5161260 \\
\hline C & -5.4728700 & -0.2664680 & 0.7779470 \\
\hline $\mathrm{H}$ & -3.8496320 & 0.0773020 & -0.6087480 \\
\hline C & -5.09 & -1.95 & 2.4726450 \\
\hline $\mathrm{H}$ & -3.19 & -2.9708190 & 2.4089210 \\
\hline C & 3.0900820 & 1.8415900 & -1.8975490 \\
\hline O & 1.6092170 & -0.0279400 & -2.4749050 \\
\hline C & 2.78 & 2.9606550 & 0.2502530 \\
\hline $\mathrm{H}$ & 1.1545010 & 2.2036390 & 1.4453920 \\
\hline C & 2.7389990 & -2.2657810 & 4.5009360 \\
\hline $\mathrm{H}$ & 3.2407200 & -3.0278800 & 2.5394250 \\
\hline C & 0.9502 & -0.6274680 & 4.5901590 \\
\hline $\mathrm{H}$ & 0.0493 & -0.1053900 & 2.6847310 \\
\hline C & 5.2878680 & -1.1872120 & -0.3480790 \\
\hline $\mathrm{H}$ & 3.7292950 & -0.1047460 & 0.6871590 \\
\hline C & 4.6747800 & -3.3538280 & -1.2473940 \\
\hline $\mathrm{H}$ & 2.6425020 & -3.9899190 & -0.9151570 \\
\hline C & -2.5362350 & -3.6143640 & -4.1125910 \\
\hline $\mathrm{H}$ & -4.2718030 & -4.5393990 & -3.1951530 \\
\hline $\mathrm{H}$ & -0.7664090 & -2.5418680 & -4.7544800 \\
\hline C & -5.9225180 & -0.9906150 & 1.8918790 \\
\hline $\mathrm{H}$ & -6.1081910 & 0.5020010 & 0.3269220 \\
\hline $\mathrm{H}$ & -5.4364190 & -2.5264890 & 3.3440990 \\
\hline C & 3.4675220 & 2.8202810 & -0.9717420 \\
\hline $\mathrm{H}$ & 3.6459600 & 1.7784330 & -2.8353220 \\
\hline
\end{tabular}




$\begin{array}{lrrr}\mathrm{C} & 2.3770410 & -0.2185490 & -3.6628010 \\ \mathrm{O} & 3.2134980 & 3.9506050 & 1.1006680 \\ \mathrm{C} & 1.9201750 & -1.4000960 & 5.2421240 \\ \mathrm{H} & 3.5039410 & -2.8646650 & 5.0062380 \\ \mathrm{H} & 0.3131950 & 0.0551050 & 5.1618220 \\ \mathrm{C} & 5.6346980 & -2.3530620 & -1.0458010 \\ \mathrm{H} & 6.0282470 & -0.3962180 & -0.1933730 \\ \mathrm{H} & 4.9373250 & -4.2677440 & -1.7906120 \\ \mathrm{H} & -2.7195850 & -4.0601120 & -5.0957740 \\ \mathrm{H} & -6.9155100 & -0.7957360 & 2.3098630 \\ \mathrm{Cl} & 4.8147030 & 3.8897460 & -1.3555870 \\ \mathrm{H} & 3.4319970 & -0.4488920 & -3.4289230 \\ \mathrm{H} & 1.9271180 & -1.0771760 & -4.1804090 \\ \mathrm{H} & 2.3309670 & 0.6657140 & -4.3247660 \\ \mathrm{C} & 2.4717450 & 4.1488090 & 2.3048320 \\ \mathrm{H} & 2.0438960 & -1.3245320 & 6.3274270 \\ \mathrm{H} & 6.6508610 & -2.4803180 & -1.4331160 \\ \mathrm{H} & 1.4150030 & 4.3900810 & 2.0942070 \\ \mathrm{H} & 2.9503190 & 5.0011840 & 2.8053420 \\ \mathrm{H} & 2.5219160 & 3.2623200 & 2.9630510 \\ \mathrm{C} & -1.3009440 & 1.2836910 & -0.2456380 \\ \mathrm{C} & -1.8525620 & 2.0011970 & -1.2888990 \\ \mathrm{C} & -2.7407070 & 3.0659470 & -0.8562130 \\ \mathrm{C} & -2.8462500 & 3.1682770 & 0.5614010 \\ \mathrm{C} & -3.6500240 & 4.1344520 & 1.1815340 \\ \mathrm{H} & -3.7148830 & 4.1947070 & 2.2730080 \\ \mathrm{C} & -4.3692140 & 5.0250700 & 0.3743190 \\ \mathrm{H} & -5.0013290 & 5.7882460 & 0.8402970 \\ \mathrm{C} & -4.2813320 & 4.9453700 & -1.0310910 \\ \mathrm{H} & -4.8477640 & 5.6509170 & -1.6484050 \\ \mathrm{C} & -3.4783370 & 3.9798810 & -1.6446680 \\ \mathrm{H} & -3.4169680 & 3.9312970 & -2.7374460 \\ \mathrm{C} & -1.5581120 & 1.7524400 & -2.7459040 \\ \mathrm{H} & -2.4523610 & 1.4124190 & -3.3017560 \\ \mathrm{H} & -1.2042660 & 2.6733900 & -3.2447650 \\ \mathrm{H} & -0.7748390 & 0.9904070 & -2.8625350 \\ \mathrm{~S} & -1.8509890 & 1.9252850 & 1.3230470 \\ 89 & & & \\ \mathrm{Ar}= & \mathrm{methyl} \mathrm{lbenzothiophene} \mathrm{TS} & \\ \mathrm{C} & 1.7130620 & 2.1621420 & 0.3978690 \\ \mathrm{C} & 2.7598110 & 1.7954530 & -2.1586740 \\ \mathrm{C} & 0.9926470 & 1.3237910 & -0.5003510 \\ \mathrm{H} & 3.2144220 & 1.6458430 & -3.1399680\end{array}$




\begin{tabular}{|c|c|c|c|}
\hline $\mathrm{Ni}$ & -0.1160020 & -0.2313600 & -0.0418000 \\
\hline$P$ & -1.7943680 & -1.6860310 & 0.0793600 \\
\hline 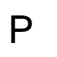 & 1.2505680 & -1.7776570 & 0.7638960 \\
\hline C & -1.1687340 & -3.1065880 & 8840 \\
\hline C & -2.1932810 & -2.5841290 & -1.4987180 \\
\hline 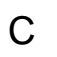 & -3.4589520 & -1.2891710 & 0.7678900 \\
\hline C & 0.2943310 & -3.3999120 & 0.7794440 \\
\hline C & 2.8880950 & -2.2032320 & 0.0243150 \\
\hline C & 1.6513630 & -1.5619890 & 2.5655420 \\
\hline $\mathrm{H}$ & -1.2387000 & -2.7805880 & 2.2025190 \\
\hline $\mathrm{H}$ & -1.7937680 & -4.0073730 & 1.0290150 \\
\hline C & -3.3793480 & -3.3250370 & -1.6676550 \\
\hline C & -1.2464930 & -2.5561240 & -2.5412350 \\
\hline$\checkmark$ & -4.0922690 & -2.04 & 1.7762660 \\
\hline C & -4.1058310 & -0.1429840 & 0.2609400 \\
\hline $\mathrm{H}$ & 0.3448070 & -3.8224340 & -0.23 \\
\hline $\mathrm{H}$ & 0.7451010 & -4.1281010 & 1.4744420 \\
\hline C & 3.8131540 & -1.15 & -0.14 \\
\hline C & 3.2404790 & -3.4969980 & -0.4083470 \\
\hline C & 2.7241880 & -2.2332840 & 3.1846760 \\
\hline C & 0.8267680 & -0.7258950 & 3.3433680 \\
\hline C & -3.6083040 & -4.0329880 & -2.8549500 \\
\hline $\mathrm{H}$ & -4.1337870 & -3.3377330 & -0.8741570 \\
\hline C & -1.4731910 & -3.2765290 & -3.7230690 \\
\hline $\mathrm{H}$ & -0.3397160 & -1.9523900 & -2.4226890 \\
\hline C & -5.3524840 & -1.6602990 & 2.2603390 \\
\hline $\mathrm{H}$ & -3.6103040 & -2.9316860 & 2.1920700 \\
\hline C & -5.3669590 & 0.2297000 & 0.7398000 \\
\hline $\mathrm{H}$ & -3.6116580 & 0.4678000 & -0.5019200 \\
\hline C & 5.0649890 & -1.3933780 & -0.7253320 \\
\hline $\mathrm{H}$ & 3.5513540 & -0.1360000 & 0.1690140 \\
\hline C & 4.4927100 & 43860 & -0.9945770 \\
\hline $\mathrm{H}$ & 2.5452530 & -4.3329570 & -0.2868030 \\
\hline C & 2.9597080 & -2.0767420 & 4.5569250 \\
\hline $\mathrm{H}$ & 3.3863490 & -2.8712330 & 2.5901640 \\
\hline C & 1.0588390 & -0.5778330 & 4.7183080 \\
\hline $\mathrm{H}$ & 0.0047020 & -0.1823440 & 2.8633140 \\
\hline C & -2.6537470 & -4.0149070 & -3.8825220 \\
\hline $\mathrm{H}$ & -4.5374520 & -4.5994010 & -2.9790920 \\
\hline $\mathrm{H}$ & -0.7292170 & -3.2549600 & -4.5267140 \\
\hline C & -5.9934250 & -0.5280580 & 1.7403450 \\
\hline $\mathrm{H}$ & -5.8338940 & -2.2532630 & 3.0453740 \\
\hline $\mathrm{H}$ & -5.8528280 & 1.1253560 & 0.3404870 \\
\hline
\end{tabular}




$\begin{array}{lrrr}\mathrm{C} & 5.4082530 & -2.6854160 & -1.1511100 \\ \mathrm{H} & 5.7710920 & -0.5660820 & -0.8485170 \\ \mathrm{H} & 4.7533420 & -4.7459240 & -1.3239570 \\ \mathrm{C} & 2.1259650 & -1.2521970 & 5.3270170 \\ \mathrm{H} & 3.8005980 & -2.5984050 & 5.0262770 \\ \mathrm{H} & 0.4089300 & 0.0738490 & 5.3116170 \\ \mathrm{H} & -2.8340930 & -4.5699550 & -4.8090140 \\ \mathrm{H} & -6.9766290 & -0.2312820 & 2.1200250 \\ \mathrm{H} & 6.3862660 & -2.8728620 & -1.6063280 \\ \mathrm{H} & 2.3131260 & -1.1307490 & 6.3990410 \\ \mathrm{H} & 1.2869700 & 2.3330530 & 1.3876460 \\ \mathrm{C} & 2.8968470 & 2.8232250 & 0.0491630 \\ \mathrm{O} & 3.6039620 & 3.6489700 & 0.8868540 \\ \mathrm{C} & 3.0619090 & 3.8884620 & 2.1868180 \\ \mathrm{H} & 2.0603560 & 4.3501990 & 2.1275000 \\ \mathrm{H} & 3.7591950 & 4.5857060 & 2.6697850 \\ \mathrm{H} & 3.0037570 & 2.9575700 & 2.7791100 \\ \mathrm{C} & 1.5840390 & 1.1292690 & -1.7887390 \\ \mathrm{O} & 0.9816300 & 0.1782320 & -2.5981380 \\ \mathrm{C} & 1.4624010 & 0.0531600 & -3.9375020 \\ \mathrm{H} & 2.5020960 & -0.3194650 & -3.9612050 \\ \mathrm{H} & 0.8042880 & -0.6774700 & -4.4268770 \\ \mathrm{H} & 1.4024910 & 1.0153990 & -4.4780930 \\ \mathrm{C} & 3.4069160 & 2.6446390 & -1.2548440 \\ \mathrm{Cl} & 4.8696420 & 3.4822180 & -1.7536810 \\ \mathrm{C} & -0.8061710 & 1.5276310 & -0.3392780 \\ \mathrm{C} & -1.5034480 & 2.2744180 & -1.3035380 \\ \mathrm{C} & -2.4253980 & 3.2356110 & -0.7403800 \\ \mathrm{C} & -2.4499590 & 3.2365810 & 0.6866050 \\ \mathrm{C} & -3.2877810 & 4.0822380 & 1.4233910 \\ \mathrm{H} & -3.2872560 & 4.0556030 & 2.5178980 \\ \mathrm{C} & -4.1234550 & 4.9692610 & 0.7311880 \\ \mathrm{H} & -4.7805660 & 5.6435380 & 1.2898760 \\ \mathrm{C} & -4.1147380 & 4.9978750 & -0.6782490 \\ \mathrm{H} & -4.7692000 & 5.6975270 & -1.2088850 \\ \mathrm{C} & -3.2803980 & 4.1486190 & -1.4087930 \\ \mathrm{H} & -3.2908650 & 4.1927280 & -2.5027050 \\ \mathrm{~S} & -1.3347570 & 2.0279940 & 1.3179800 \\ \mathrm{C} & -1.2667600 & 2.1737610 & -2.7838760 \\ \mathrm{H} & -2.0603840 & 2.6817100 & -3.3532870 \\ \mathrm{H} & -0.3060770 & 2.6475180 & -3.0686570 \\ \mathrm{H} & -1.2176860 & 1.1285810 & -3.1225980 \\ 96 & & & \\ & & & \end{array}$




\begin{tabular}{|c|c|c|c|}
\hline \multicolumn{4}{|c|}{$\mathrm{Ar}=$ methyl-parabiphenyl reactant } \\
\hline C & 1.2693540 & 2.3603920 & 0.9342100 \\
\hline ; & 1.7747280 & 3.2627540 & -1.6503070 \\
\hline C & 0.9940070 & 1.4913620 & -0.1375340 \\
\hline $\mathrm{H}$ & 1.9819410 & 3.6483410 & -2.6506930 \\
\hline $\mathrm{Ni}$ & 0.3429140 & -0.3102160 & 0.0603530 \\
\hline$P$ & -0.4260640 & -2.3894330 & 0.0457000 \\
\hline & 2.3937460 & -1.1792280 & 0.1829450 \\
\hline C & 0.9818530 & -3.5388040 & 0.5333060 \\
\hline C & -0.7916230 & -2.9727080 & -1.6770000 \\
\hline C & -1.8834940 & -2.9857400 & 1.0072440 \\
\hline C & 2.2607550 & -3.0280420 & -0.1448480 \\
\hline C & 3.8217550 & -0.6142110 & -0.8398850 \\
\hline C & 3.0878130 & -1.1613150 & 1.9052210 \\
\hline $\mathrm{H}$ & 1.0933720 & -3.4940430 & 1.6303050 \\
\hline $\mathrm{H}$ & 0.7613770 & -4.5821130 & 0.2524740 \\
\hline C & -1.4636240 & -4.1870980 & -1.9194230 \\
\hline C & -0.3317430 & -2.2068060 & -2.7651400 \\
\hline C & -1.7749550 & -3.9174340 & 2.0588760 \\
\hline C & -3.1513960 & -2.4493650 & 0.6951440 \\
\hline $\mathrm{H}$ & 2.1869900 & -3.1721310 & -1.2363660 \\
\hline $\mathrm{H}$ & 3.1552780 & -3.5635850 & 0.2138980 \\
\hline C & 4.2894210 & 0.7050440 & -0.6584520 \\
\hline C & 4.4406070 & -1.4306930 & -1.8065740 \\
\hline C & 4.4501710 & -1.4083440 & 2.1657470 \\
\hline C & 2.2111620 & -0.9462580 & 2.9852720 \\
\hline C & -1.6644560 & -4.6323950 & -3.2318990 \\
\hline $\mathrm{H}$ & -1.8447280 & -4.7796980 & -1.0810450 \\
\hline C & -0.5315150 & -2.6600350 & -4.0779050 \\
\hline $\mathrm{H}$ & 0.1712170 & -1.2507000 & -2.5782810 \\
\hline $\mathrm{C}$ & -2.9116600 & -4.3096340 & 2.7805320 \\
\hline $\mathrm{H}$ & -0.8058690 & -4.3502550 & 2.3237220 \\
\hline $\mathrm{C}$ & -4.2828340 & -2.8466440 & 1.4173630 \\
\hline $\mathrm{H}$ & -3.2528500 & -1.7147040 & -0.1090210 \\
\hline C & 5.3594290 & 1.1874090 & -1.4215610 \\
\hline $\mathrm{H}$ & 3.8132770 & 1.3581660 & 0.0788600 \\
\hline $\mathrm{C}$ & 5.5105110 & -0.9418520 & -2.5704020 \\
\hline $\mathrm{H}$ & 4.1006060 & -2.4569850 & -1.9716680 \\
\hline C & 4.9214010 & -1.4468750 & 3.4843650 \\
\hline $\mathrm{H}$ & 5.1478430 & -1.5572240 & 1.3351970 \\
\hline C & 2.6838750 & -0.9904450 & 4.3049250 \\
\hline $\mathrm{H}$ & 1.1554170 & -0.7344230 & 2.7837090 \\
\hline C & -1.1962470 & -3.8705840 & -4.3131470 \\
\hline
\end{tabular}




\begin{tabular}{|c|c|c|c|}
\hline $\mathrm{H}$ & -2.1927890 & -5.5746260 & -3.4116730 \\
\hline $\mathrm{H}$ & -0.1743530 & -2.0596260 & -4.9211210 \\
\hline C & -4.1671320 & -3.7764870 & 2.4607170 \\
\hline & -2.8124680 & -5.0373190 & 3.5928440 \\
\hline & -5.2584890 & -2.4189850 & 1.1662850 \\
\hline & 5.9735290 & 0.3663660 & -2.3783190 \\
\hline & 5.7090290 & 2.2132820 & -1.2690510 \\
\hline & 5.9845700 & -1.5905900 & -3.3145280 \\
\hline & 4.0395350 & -1.2404100 & 4.5559140 \\
\hline & 5.9832100 & -1.6340780 & 3.6760650 \\
\hline & 1.9923220 & -0.8209100 & 5.1368480 \\
\hline & -1.3570560 & -4.2186540 & -5.3388340 \\
\hline & -5.0539160 & -4.0829390 & 3.0250130 \\
\hline & 6.8102 & 0.7462920 & -2.9736080 \\
\hline & 4.4116250 & -1.2683180 & 5.5852920 \\
\hline & -1.4229900 & 0.4698530 & 0.0492190 \\
\hline & -3.4551190 & 1.2418030 & 1.1709110 \\
\hline & -3.801 & 1.5239260 & -2.2071620 \\
\hline & 1.0789550 & 2.0180080 & 1.9544390 \\
\hline & -4.0095520 & 1.3969410 & 2.1051910 \\
\hline & -2.1520490 & 0.7180020 & 1.2429270 \\
\hline C & 1.7906780 & 3.6599510 & 0.7558650 \\
\hline & 2.0801620 & 4.5362860 & 1.7753990 \\
\hline C & 1.7673700 & 1700 & 3.1051510 \\
\hline r & 0.6888220 & 3.9166200 & 3.2210260 \\
\hline r & 2.0439080 & 4.9756340 & 3.7454250 \\
\hline r & 2.3498600 & 3.2372710 & 3.4065880 \\
\hline C & 1.2627200 & 1.9729450 & -1.4374470 \\
\hline $\mathrm{C}$ & 1.0071780 & 1.0897770 & -2.4854130 \\
\hline C & 1.2507050 & 1.5590890 & -3.8101500 \\
\hline r & 2.3144210 & 1.8184890 & -3.9620620 \\
\hline $\mathrm{H}$ & 0.9852310 & 0.7292660 & -4.4799510 \\
\hline $\mathrm{H}$ & 0.6214490 & 2.4350560 & -4.0531670 \\
\hline C & 2.0375500 & 4.0958520 & -0.5569250 \\
\hline $\mathrm{Cl}$ & 2.6875470 & 5.7091270 & -0.8427520 \\
\hline C & -4.0921640 & 1.5279840 & -0.0537850 \\
\hline C & -3.3616190 & 1.2802530 & -1.2331180 \\
\hline C & -2.0557070 & 0.7757870 & -1.1746300 \\
\hline C & -5.4743530 & 2.0695900 & -0.0957560 \\
\hline 0 & -6.3839940 & 1.6716120 & -1.1010270 \\
\hline C & -5.9254200 & 3.0009410 & 0.8660490 \\
\hline C & -7.6873730 & 2.1810780 & -1.1429680 \\
\hline 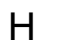 & -6.0687220 & 0.9333370 & -1.8460440 \\
\hline
\end{tabular}




$\begin{array}{lrrr}\mathrm{C} & -7.2297220 & 3.5082670 & 0.8279820 \\ \mathrm{H} & -5.2314190 & 3.3528640 & 1.6364510 \\ \mathrm{C} & -8.1190030 & 3.1015000 & -0.1770310 \\ \mathrm{H} & -8.3738570 & 1.8498280 & -1.9299220 \\ \mathrm{H} & -7.5497820 & 4.2367270 & 1.5810390 \\ \mathrm{H} & -9.1383780 & 3.5000640 & -0.2087310 \\ \mathrm{C} & -1.5664750 & 0.4018460 & 2.6019600 \\ \mathrm{H} & -1.3133200 & -0.6703150 & 2.6893060 \\ \mathrm{H} & -0.6389230 & 0.9710310 & 2.7845250 \\ \mathrm{H} & -2.2698340 & 0.6422740 & 3.4164340 \\ \mathrm{H} & -1.5104780 & 0.6331240 & -2.1127040 \\ \mathrm{96} & & & \\ \mathrm{Ar}= & \mathrm{methyl}-\mathrm{parabiph} & \\ \mathrm{C} & 0.8962700 & 2.6707080 & 0.2739400 \\ \mathrm{C} & 2.2749860 & 2.6273840 & -2.1383540 \\ \mathrm{C} & 0.7257720 & 1.5257720 & -0.5556260 \\ \mathrm{H} & 2.8540150 & 2.6258070 & -3.0638150 \\ \mathrm{Ni} & 0.3581610 & -0.3419390 & -0.0507600 \\ \mathrm{P} & -0.5331620 & -2.3781220 & 0.0059000 \\ \mathrm{P} & 2.2020210 & -1.1321000 & 0.8687960 \\ \mathrm{C} & 0.6403030 & -3.4291180 & 1.0502090 \\ \mathrm{C} & -0.5405130 & -3.3454630 & -1.5840770 \\ \mathrm{C} & -2.1960880 & -2.7488520 & 0.7255770 \\ \mathrm{C} & 2.0900320 & -3.0095560 & 0.7644760 \\ \mathrm{C} & 3.9052530 & -0.7359910 & 0.2726550 \\ \mathrm{C} & 2.3444450 & -0.8778080 & 2.7073460 \\ \mathrm{H} & 0.3936850 & -3.2392040 & 2.1095850 \\ \mathrm{H} & 0.4944870 & -4.5048030 & 0.8551620 \\ \mathrm{C} & -1.3845500 & -4.4516270 & -1.8023150 \\ \mathrm{C} & 0.3724360 & -2.9716050 & -2.5900290 \\ \mathrm{C} & -2.4316410 & -3.7757180 & 1.6623620 \\ \mathrm{C} & -3.2745580 & -1.9349320 & 0.3219030 \\ \mathrm{H} & 2.3725410 & -3.2994060 & -0.2628670 \\ \mathrm{H} & 2.7911850 & -3.4975950 & 1.4624570 \\ \mathrm{C} & 4.2632810 & 0.6265170 & 0.1864190 \\ \mathrm{C} & 4.8397060 & -1.7107920 & -0.1301660 \\ \mathrm{C} & 3.5743870 & -0.9464780 & 3.3908230 \\ \mathrm{C} & 1.1678620 & -0.6428770 & 3.4460530 \\ \mathrm{C} & -1.3088220 & -5.1748850 & -3.0005260 \\ \mathrm{H} & -2.1121520 & -4.7432190 & -1.0381700 \\ \mathrm{C} & 0.4561500 & -3.7066720 & -3.7811050 \\ \mathrm{H} & 1.0023670 & -2.0887010 & -2.4355620 \\ \mathrm{C} & -3.7183680 & -3.9864330 & 2.1791080\end{array}$




\begin{tabular}{|c|c|c|c|}
\hline $\mathrm{H}$ & -1.6148470 & -4.4236720 & 1.9942520 \\
\hline $\mathrm{O}$ & -4.5596980 & -2.1529310 & 0.8335490 \\
\hline ト & -3.1055960 & -1.1178430 & -0.3865800 \\
\hline & 5.5303870 & 1.0010660 & -0.2763030 \\
\hline & 3.5448340 & 1.3993260 & 0.4790670 \\
\hline & 6.1053180 & -1.3319240 & -0.6020190 \\
\hline & 4.5921680 & -2.7749430 & -0.0732000 \\
\hline & 3.6223540 & -0.7891960 & 4.7826840 \\
\hline & 4.5010060 & -1.1120710 & 2.8319960 \\
\hline & 1.2155340 & -0.4975220 & 4.8394570 \\
\hline r & 0.2095870 & -0.5695360 & 2.9189350 \\
\hline & -0.3849450 & -4.8085270 & -3.9897140 \\
\hline 卜 & -1.9764250 & -6.0279950 & -3.1623840 \\
\hline & 1.1732200 & -3.4127440 & -4.5553390 \\
\hline C & -4.7850300 & -3.1780400 & 1.7635200 \\
\hline 卜 & -3.8859420 & -4.7877560 & 2.9068310 \\
\hline 卜 & -5.3840160 & -1.5071560 & 0.5148840 \\
\hline C & 6.4549090 & 0.0231780 & -0.6725150 \\
\hline 卜 & 5.7910360 & 2.0625570 & -0.33 \\
\hline 卜 & 6.8215290 & -2.1016110 & -0.9092130 \\
\hline C & 2.4441070 & -0.5683380 & 5.5105170 \\
\hline $\mathrm{H}$ & 4.5861410 & -0.8375260 & 5.3007470 \\
\hline I & 0.2917540 & -0.3192360 & 5.4000260 \\
\hline $\mathrm{H}$ & -0.3265700 & -5.3760660 & -4.9242960 \\
\hline $\mathrm{H}$ & -5.7889060 & -3.3419260 & 2.1689170 \\
\hline$\vdash$ & 7.4441030 & 0.3174260 & -1.0383650 \\
\hline . & 2.4847480 & -0.4453650 & 6.597 \\
\hline C & -1.0376300 & 0.9682170 & -0.4411410 \\
\hline . & -2.9427270 & 1.5965990 & 1.0151300 \\
\hline $\mathrm{H}$ & -3.8306750 & 1.7686860 & -2.2622780 \\
\hline $\mathrm{H}$ & 0.3164330 & 2.7196900 & 1.1973340 \\
\hline $\mathrm{H}$ & -3.3419360 & 1.7013870 & 2.0299900 \\
\hline C & -1.6163380 & 1.2150490 & 0.8431280 \\
\hline C & 1.7009260 & 3.7650410 & -0.0629640 \\
\hline $\mathrm{O}$ & 1.8691830 & 4.8828550 & 0.7169630 \\
\hline$\Omega$ & 1.1419730 & 4.9469360 & 1.9436760 \\
\hline $\mathrm{H}$ & 0.0515670 & 4.9111180 & 1.7700320 \\
\hline $\mathrm{H}$ & 1.4090720 & 5.9131320 & 2.3917830 \\
\hline $\mathrm{H}$ & 1.4325420 & 4.1312770 & 2.6305390 \\
\hline C & 1.4821640 & 1.5302280 & -1.7701740 \\
\hline $\mathrm{O}$ & 1.4734340 & 0.3538980 & -2.5057620 \\
\hline C & 2.0961820 & 0.3749910 & -3.7912540 \\
\hline $\mathrm{H}$ & 3.1882700 & 0.5196940 & -3.7100950 \\
\hline
\end{tabular}




$\begin{array}{lrrr}\mathrm{H} & 1.8947930 & -0.6069690 & -4.2403740 \\ \mathrm{H} & 1.6655850 & 1.1631480 & -4.4357160 \\ \mathrm{C} & 2.3786230 & 3.7405530 & -1.3005640 \\ \mathrm{Cl} & 3.3605620 & 5.1107720 & -1.7984260 \\ \mathrm{C} & -3.7858190 & 1.8014790 & -0.1010290 \\ \mathrm{C} & -3.2151110 & 1.5863840 & -1.3731930 \\ \mathrm{C} & -1.8868670 & 1.1769980 & -1.5768760 \\ \mathrm{H} & -0.9998350 & 1.0763570 & 1.7398020 \\ \mathrm{C} & -5.1985400 & 2.2174020 & 0.0560310 \\ \mathrm{C} & -6.1967710 & 1.7902330 & -0.8509410 \\ \mathrm{C} & -5.6015440 & 3.0540280 & 1.1228800 \\ \mathrm{C} & -7.5318980 & 2.1808580 & -0.6991730 \\ \mathrm{H} & -5.9244750 & 1.1214150 & -1.6741290 \\ \mathrm{C} & -6.9373250 & 3.4415320 & 1.2779790 \\ \mathrm{H} & -4.8488950 & 3.4303250 & 1.8233390 \\ \mathrm{C} & -7.9121580 & 3.0080710 & 0.3678030 \\ \mathrm{H} & -8.2832910 & 1.8284740 & -1.4142960 \\ \mathrm{H} & -7.2170980 & 4.0978380 & 2.1092900 \\ \mathrm{H} & -8.9567350 & 3.3134490 & 0.4871520 \\ \mathrm{C} & -1.4105560 & 1.0036600 & -2.9965460 \\ \mathrm{H} & -0.6713160 & 1.7814580 & -3.2641560 \\ \mathrm{H} & -0.9149790 & 0.0325420 & -3.1480740 \\ \mathrm{H} & -2.2500150 & 1.0850940 & -3.7052760\end{array}$




\begin{tabular}{|c|c|c|c|}
\hline \multicolumn{4}{|c|}{$\mathrm{X}=\mathrm{Br}$} \\
\hline \multicolumn{4}{|c|}{97} \\
\hline \multicolumn{4}{|c|}{$\mathrm{R}=\mathrm{OMe}$ reactant } \\
\hline C & 1.4108450 & 1.8665120 & 0.8944370 \\
\hline C & 2.3833920 & 2.5956060 & -1.6146480 \\
\hline C & 1.1387750 & 1.0247550 & -0.1983060 \\
\hline $\mathrm{H}$ & 2.7722140 & 2.9095420 & -2.5853300 \\
\hline $\mathrm{Ni}$ & 0.1709470 & -0.6282970 & -0.0527250 \\
\hline$P$ & -0.9626520 & -2.5302810 & -0.1010300 \\
\hline$P$ & 1.9968890 & -1.8381100 & 0.2858030 \\
\hline $\mathrm{C}$ & 0.1661610 & -3.9025940 & 0.5178460 \\
\hline C & -1.2976720 & -3.0782360 & -1.8410060 \\
\hline C & -2.5757280 & -2.8195690 & 0.7466890 \\
\hline C & 1.5733710 & -3.6423880 & -0.0380200 \\
\hline C & 3.6179220 & -1.5679790 & -0.5516800 \\
\hline C & 2.4537660 & -1.8797040 & 2.0837480 \\
\hline $\mathrm{H}$ & 0.1838380 & -3.8537530 & 1.6200800 \\
\hline $\mathrm{H}$ & -0.2113780 & -4.8958320 & 0.2230940 \\
\hline C & -2.1403120 & -4.1709180 & -2.1258310 \\
\hline C & -0.6493670 & -2.4098730 & -2.8970620 \\
\hline C & -2.7270850 & -3.7303170 & 1.8105430 \\
\hline C & -3.6932280 & -2.0670880 & 0.3259180 \\
\hline $\mathrm{H}$ & 1.5808030 & -3.7988760 & -1.1303580 \\
\hline $\mathrm{H}$ & 2.3204370 & -4.3172800 & 0.4118860 \\
\hline C & 4.2942330 & -0.3518670 & -0.3160850 \\
\hline C & 4.1868020 & -2.5058840 & -1.4352800 \\
\hline C & 3.6746780 & -2.4232790 & 2.5294180 \\
\hline C & 1.5258690 & -1.3977340 & 3.0270370 \\
\hline C & -2.3238170 & -4.5943170 & -3.4480010 \\
\hline $\mathrm{H}$ & -2.6670310 & -4.6832510 & -1.3136790 \\
\hline C & -0.8344140 & -2.8400280 & -4.2197520 \\
\hline $\mathrm{H}$ & -0.0102320 & -1.5462370 & -2.6771000 \\
\hline C & -3.9719050 & -3.8923980 & 2.4361250 \\
\hline $\mathrm{H}$ & -1.8791760 & -4.3262950 & 2.1601330 \\
\hline C & -4.9338460 & -2.2338520 & 0.9527700 \\
\hline $\mathrm{H}$ & -3.5917360 & -1.3450040 & -0.4897760 \\
\hline C & 5.5178830 & -0.0903850 & -0.9438970 \\
\hline $\mathrm{H}$ & 3.8605740 & 0.3943050 & 0.3564000 \\
\hline C & 5.4116180 & -2.2379700 & -2.0638220 \\
\hline $\mathrm{H}$ & 3.6849710 & -3.4559640 & -1.6398760 \\
\hline
\end{tabular}




\begin{tabular}{|c|c|c|c|}
\hline $\mathrm{C}$ & 3.9584800 & -2.4921800 & 3.8991790 \\
\hline $\mathrm{H}$ & 4.4126930 & -2.7800450 & 1.8032290 \\
\hline C & 1.8129760 & -1.4732280 & 4.3984290 \\
\hline $\mathrm{H}$ & 0.5850030 & -0.9545480 & 2.6785780 \\
\hline C & -1.6692580 & -3.9304510 & -4.4967740 \\
\hline $\mathrm{H}$ & -2.9846680 & -5.4410890 & -3.6614920 \\
\hline $\mathrm{H}$ & -0.3314390 & -2.3146320 & -5.0382950 \\
\hline $\mathrm{C}$ & -5.0778530 & -3.1467150 & 2.0077320 \\
\hline $\mathrm{H}$ & -4.0750060 & -4.6084340 & 3.2583540 \\
\hline $\mathrm{H}$ & -5.7902950 & -1.6410500 & 0.6165010 \\
\hline C & 6.0804910 & -1.0317430 & -1.8180330 \\
\hline $\mathrm{H}$ & 6.0287940 & 0.8583070 & -0.7519290 \\
\hline $\mathrm{H}$ & 5.8438700 & -2.9789900 & -2.7445550 \\
\hline $\mathrm{C}$ & 3.0268270 & -2.0195580 & 4.8358860 \\
\hline $\mathrm{H}$ & 4.9123870 & -2.9109750 & 4.2367130 \\
\hline $\mathrm{H}$ & 1.0883850 & -1.0967010 & 5.1281500 \\
\hline$H$ & -1.8173770 & -4.2601060 & -5.5304490 \\
\hline $\mathrm{H}$ & -6.0497000 & -3.2750050 & 2.4955440 \\
\hline $\mathrm{H}$ & 7.037 & -0.8242610 & -2.3078770 \\
\hline $\mathrm{H}$ & 3.2517640 & -2.0717040 & 5.9062940 \\
\hline C & -1.4019870 & 0.4653170 & -0.1755570 \\
\hline C & -3.1461400 & 1.6618280 & -1.4372480 \\
\hline $\mathrm{H}$ & -3.7820080 & 1.8622620 & 1.9014990 \\
\hline $\mathrm{H}$ & 1.0090750 & 1.5953000 & 1.8739090 \\
\hline $\mathrm{H}$ & -3.5277160 & 2.0052670 & -2.4049690 \\
\hline C & -1.9618390 & 0.9080870 & -1.3867820 \\
\hline C & 2.1657 & 3330 & 0.7732 \\
\hline $\mathrm{O}$ & 2.4645990 & 82170 & 1.8168270 \\
\hline C & 1.9460090 & 3.5660820 & 3.1027830 \\
\hline $\mathrm{H}$ & 0.8414060 & 3.5384750 & 3.0995930 \\
\hline $\mathrm{H}$ & 2.2890670 & 4.3664420 & 3.7722850 \\
\hline $\mathrm{H}$ & 2.3355420 & 2.5957220 & 3.4610930 \\
\hline C & 1.6354810 & 1.4169640 & -1.4593060 \\
\hline $\mathrm{O}$ & 1.3488370 & 0.5649230 & -2.5244300 \\
\hline C & 1.8319770 & 0.9431610 & -3.8119250 \\
\hline $\mathrm{H}$ & 2.9354070 & 1.0062750 & -3.8314740 \\
\hline $\mathrm{H}$ & 1.5061160 & 0.1529390 & -4.5026250 \\
\hline $\mathrm{H}$ & 1.4042530 & 1.9087200 & -4.1395160 \\
\hline C & 2.6476340 & 3.4002480 & -0.4999000 \\
\hline $\mathrm{Br}$ & 3.6821730 & 5.0038230 & -0.7325670 \\
\hline C & -3.8115140 & 2.0274250 & -0.2532320 \\
\hline C & -3.2542530 & 1.6100690 & 0.9776900 \\
\hline $\mathrm{C}$ & -2.0791570 & 0.8450400 & 1.0073080 \\
\hline
\end{tabular}




\begin{tabular}{|c|c|c|c|}
\hline $\mathrm{H}$ & -1.4534830 & 0.6704160 & -2.3270970 \\
\hline C & -5.0583220 & 2.8343070 & -0.2829120 \\
\hline C & -5.3127670 & 3.8270780 & 0.6895000 \\
\hline C & -6.0308740 & 2.6363900 & -1.2885780 \\
\hline C & -6.4891620 & 4.5856960 & 0.6611310 \\
\hline $\mathrm{H}$ & -4.5599460 & 4.0280280 & 1.4589790 \\
\hline C & -7.2055590 & 3.3972270 & -1.3211310 \\
\hline $\mathrm{H}$ & -5.8701170 & 1.8576560 & -2.0415470 \\
\hline C & -7.4431890 & 4.3753570 & -0.3446620 \\
\hline $\mathrm{H}$ & -6.6553920 & 5.3564260 & 1.4217270 \\
\hline $\mathrm{H}$ & -7.9453170 & 3.2183800 & -2.1091420 \\
\hline $\mathrm{H}$ & -8.3620870 & 4.9702700 & -0.3691630 \\
\hline O & -1.5097280 & 0.3917670 & 2.1960830 \\
\hline C & -2.1861190 & 0.7064120 & 3.4122770 \\
\hline $\mathrm{H}$ & -1.5917360 & 0.2498200 & 4.2161000 \\
\hline $\mathrm{H}$ & -2.2413250 & 1.7980700 & 3.5789740 \\
\hline$\Pi$ & -3.2063300 & 0.2827130 & 3.4323720 \\
\hline \multicolumn{4}{|c|}{97} \\
\hline \multicolumn{4}{|c|}{$\mathrm{R}=\mathrm{OMe} \mathrm{TS}$} \\
\hline C & 1.2133790 & 2.0073120 & 0.8726020 \\
\hline$u$ & 2.3898680 & 2.4958400 & -1.6030530 \\
\hline C & 0.7455680 & 1.2501300 & -0.2415010 \\
\hline $\mathrm{H}$ & 2.8898460 & 2.6878790 & -2.5538770 \\
\hline $\mathrm{Ni}$ & 0.1522430 & -0.6152170 & -0.0519000 \\
\hline$P$ & -1.1113890 & -2.4196540 & -0.0192860 \\
\hline$P$ & 1.9347550 & -1.8812890 & 0.2342200 \\
\hline C & -0.0184980 & -3.8355730 & 0.5755520 \\
\hline C & -1.6017930 & -3.0233690 & -1.7079950 \\
\hline $\mathrm{C}$ & -2.6792370 & -2.6103250 & 0.9404020 \\
\hline C & 1.3801460 & -3.6619770 & -0.0389560 \\
\hline C & 3.5165200 & -1.7384770 & -0.7098270 \\
\hline C & 2.5256070 & -1.9546890 & 1.9962490 \\
\hline $\mathrm{H}$ & 0.0449240 & -3.7677360 & 1.6756840 \\
\hline $\mathrm{H}$ & -0.4511290 & -4.8170820 & 0.3177800 \\
\hline C & -2.5314800 & -4.0648850 & -1.8973890 \\
\hline C & -0.9877400 & -2.4374800 & -2.8314800 \\
\hline C & -2.8569780 & -3.5471310 & 1.9780760 \\
\hline C & -3.7322430 & -1.7174370 & 0.6433430 \\
\hline $\mathrm{H}$ & 1.3341660 & -3.8316290 & -1.1289010 \\
\hline $\mathrm{H}$ & 2.0990350 & -4.3806260 & 0.3896420 \\
\hline C & 4.2136610 & -0.5134560 & -0.6246230 \\
\hline C & 4.0270840 & -2.7523460 & -1.5449570 \\
\hline C & 3.7556150 & -2.5367620 & 2.3607120 \\
\hline
\end{tabular}




\begin{tabular}{|c|c|c|c|}
\hline $\mathrm{C}$ & 1.6842380 & -1.4415780 & 3.0025700 \\
\hline C & -2.8331000 & -4.5183870 & -3.1879200 \\
\hline ト & -3.0325150 & -4.5143350 & -1.0332960 \\
\hline C & -1.2876290 & -2.8974690 & -4.1224010 \\
\hline $\mathrm{H}$ & -0.2825130 & -1.6110770 & -2.6837090 \\
\hline C & -4.0619890 & -3.5967520 & 2.6949450 \\
\hline $\mathrm{H}$ & -2.0602080 & -4.2522220 & 2.2328080 \\
\hline C & -4.9361260 & -1.7750580 & 1.3550140 \\
\hline $\mathrm{H}$ & -3.6083710 & -0.9712380 & -0.14 \\
\hline C & 5.3998560 & -0.3179620 & -1.3414050 \\
\hline $\mathrm{H}$ & 3.8259460 & 0.2932230 & 0.0061690 \\
\hline C & 5.2111850 & -2.5497560 & -2.26 \\
\hline $\mathrm{H}$ & 3.5101760 & -3.7125060 & -1.63 \\
\hline C & 4.1316640 & -2.6124320 & 3.7081510 \\
\hline $\mathrm{H}$ & 4.4290820 & -2.9203040 & 1.5869290 \\
\hline C & 2.0591680 & -1.5268940 & 4.3516510 \\
\hline $\mathrm{H}$ & 0.7391450 & -0.9657360 & 2.7148280 \\
\hline C & -2.2092850 & -3.9374480 & -4.3025720 \\
\hline $\mathrm{H}$ & -3.5611080 & -5.3251620 & -3.32 \\
\hline $\mathrm{H}$ & -0.8067960 & -2.4360150 & -4.9915290 \\
\hline C & -5.1055080 & -2.7151750 & 2.3831830 \\
\hline $\mathrm{H}$ & -4.1856730 & -4.3344690 & 3.49 \\
\hline $\mathrm{H}$ & -5.7432290 & -1.0782280 & 1.1068860 \\
\hline C & 5.9027200 & -1.3354190 & -2.1667870 \\
\hline $\mathrm{H}$ & 5.9292560 & 0.6365930 & -1.2573800 \\
\hline $\mathrm{H}$ & 5.5967880 & -3.3496870 & -2.91 \\
\hline C & 3.2824620 & -2.1115670 & 4.7064210 \\
\hline $\mathrm{H}$ & 5.0929220 & -3.0613930 & 3.9802430 \\
\hline $\mathrm{H}$ & 1.3975580 & -1.1290640 & 5.1287290 \\
\hline $\mathrm{H}$ & -2.4482080 & -4.2917310 & -5.3108500 \\
\hline $\mathrm{H}$ & -6.0471250 & -2.7580490 & 2.94 \\
\hline $\mathrm{H}$ & 6.8293420 & -1.1805620 & -2.7291820 \\
\hline $\mathrm{H}$ & 3.5784650 & -2.1716140 & 5.7590080 \\
\hline C & -1.0177310 & 0.9515690 & -0.2315920 \\
\hline C & -2.9371410 & 1.8793800 & -1.4988910 \\
\hline $\mathrm{H}$ & -3.5887060 & 2.0180510 & 1.8344040 \\
\hline $\mathrm{H}$ & 0.7466330 & 1.8174790 & 1.8383360 \\
\hline $\mathrm{H}$ & -3.3631120 & 2.1360260 & -2.4744910 \\
\hline C & -1.6766030 & 1.2857240 & -1.4506690 \\
\hline C & 2.2102740 & 2.9877180 & 0.7774580 \\
\hline $\mathrm{O}$ & 2.6745890 & 3.7279320 & 1.8380520 \\
\hline C & 2.0835290 & 3.4952590 & 3.1152640 \\
\hline $\mathrm{H}$ & 1.0011530 & 3.7175430 & 3.1061650 \\
\hline
\end{tabular}




$\begin{array}{lrrr}\mathrm{H} & 2.5918320 & 4.1846670 & 3.8025800 \\ \mathrm{H} & 2.2430800 & 2.4551690 & 3.4524370 \\ \mathrm{C} & 1.4023320 & 1.5131420 & -1.4898880 \\ \mathrm{O} & 1.0330980 & 0.7124510 & -2.5583170 \\ \mathrm{C} & 1.6698000 & 0.9450010 & -3.8164990 \\ \mathrm{H} & 2.7584900 & 0.7717000 & -3.7526020 \\ \mathrm{H} & 1.2279690 & 0.2202780 & -4.5135340 \\ \mathrm{H} & 1.4774670 & 1.9686840 & -4.1855630 \\ \mathrm{C} & 2.7878220 & 3.2369020 & -0.4819290 \\ \mathrm{Br} & 4.1447480 & 4.5755640 & -0.6785200 \\ \mathrm{C} & -3.6410690 & 2.1981360 & -0.3196460 \\ \mathrm{C} & -3.0264730 & 1.8569600 & 0.9113350 \\ \mathrm{C} & -1.7756830 & 1.2425670 & 0.9569850 \\ \mathrm{H} & -1.1556640 & 1.0863140 & -2.3879940 \\ \mathrm{C} & -4.9710100 & 2.8450550 & -0.3510330 \\ \mathrm{C} & -5.3755930 & 3.7446150 & 0.6634320 \\ \mathrm{C} & -5.8882580 & 2.5855850 & -1.3970710 \\ \mathrm{C} & -6.6363580 & 4.3514180 & 0.6363050 \\ \mathrm{H} & -4.6753370 & 3.9983930 & 1.4661450 \\ \mathrm{C} & -7.1470120 & 3.1952250 & -1.4266830 \\ \mathrm{H} & -5.6177970 & 1.8734540 & -2.1835370 \\ \mathrm{C} & -7.5313930 & 4.0811630 & -0.4089200 \\ \mathrm{H} & -6.9167900 & 5.0520230 & 1.4304660 \\ \mathrm{H} & -7.8382940 & 2.9687140 & -2.2457910 \\ \mathrm{H} & -8.5168030 & 4.5576700 & -0.4320060 \\ \mathrm{O} & -1.2020890 & 0.8196380 & 2.1472400 \\ \mathrm{C} & -1.9347600 & 1.0318770 & 3.3563980 \\ \mathrm{H} & -1.3069410 & 0.6255760 & 4.1610060 \\ \mathrm{H} & -2.1130140 & 2.1067860 & 3.5409120 \\ \mathrm{H} & -2.8990150 & 0.4949180 & 3.3399850 \\ \mathrm{H} 00 & & & \\ \mathrm{R}=\mathrm{OEt} & \mathrm{reactant} & & \\ \mathrm{C} & 1.4248340 & 1.8603660 & 0.8960440 \\ \mathrm{C} & 2.3870390 & 2.6480200 & -1.5993520 \\ \mathrm{C} & 1.1566730 & 1.0391170 & -0.2132060 \\ \mathrm{H} & 2.7714410 & 2.9848390 & -2.5640930 \\ \mathrm{Ni} & 0.2002190 & -0.6229590 & -0.0962600 \\ \mathrm{P} & -0.9247590 & -2.5286160 & -0.1835070 \\ \mathrm{P} & 2.0399020 & -1.8343620 & 0.1739140 \\ \mathrm{C} & 0.2192270 & -3.9113860 & 0.3817000 \\ \mathrm{C} & -1.2745790 & -3.0339350 & -1.9338680 \\ \mathrm{C} & -2.5273740 & -2.8493010 & 0.6720850 \\ \mathrm{C} & 1.6137470 & -3.6296320 & -0.1955590\end{array}$




\begin{tabular}{|c|c|c|c|}
\hline $\mathrm{C}$ & 3.6324730 & -1.5283490 & -0.7054050 \\
\hline C & 2.5623060 & -1.9404650 & 1.9509000 \\
\hline $\mathrm{H}$ & 0.2578210 & -3.8902620 & 1.4843580 \\
\hline $\mathrm{H}$ & -0.1594720 & -4.8986530 & 0.0688580 \\
\hline C & -2.1274300 & -4.1134100 & -2.2379260 \\
\hline $\mathrm{C}$ & -0.6249220 & -2.3496080 & -2.9789130 \\
\hline C & -2.6616240 & -3.7844180 & 1.7169450 \\
\hline C & -3.6544900 & -2.0966720 & 0.2780110 \\
\hline $\mathrm{H}$ & 1.5972840 & -3.7538320 & -1.2918030 \\
\hline $\mathrm{H}$ & 2.3726170 & -4.3146490 & 0.2176250 \\
\hline C & 4.3139950 & -0.3204770 & -0.4442070 \\
\hline C & 4.1762230 & -2.4310010 & -1.6399380 \\
\hline C & 3.8006910 & -2.4957120 & 2.3292120 \\
\hline C & 1.6684440 & -1.5024130 & 2.9463600 \\
\hline C & -2.3202220 & -4.5075460 & -3.56 \\
\hline $\mathrm{H}$ & -2.6545840 & -4.6385480 & -1.4343520 \\
\hline C & -0.8189840 & -2.7505980 & -4.3094030 \\
\hline $\mathrm{H}$ & 0.0221460 & -1.4958520 & -2.7445820 \\
\hline C & -3.8993290 & -3.97 & 2.35 \\
\hline $\mathrm{H}$ & -1.8059010 & -4.3818880 & 2.0444430 \\
\hline C & -4.8878070 & -2.2868330 & 0.9125520 \\
\hline П & -3.5663840 & -1.3570080 & -0.5233810 \\
\hline C & 5.5183000 & -0.0325880 & -1.097 \\
\hline $\mathrm{H}$ & 3.8999320 & 0.3986050 & 0.2688680 \\
\hline C & 5.3816100 & -2.1367340 & -2.2938240 \\
\hline $\mathrm{H}$ & 3.6698910 & -3.3739910 & -1.8651520 \\
\hline C & 4.13 & -2.6196630 & 3.6 \\
\hline $\mathrm{H}$ & 4.5125320 & -2.8191090 & 1.56 \\
\hline C & 2.0049540 & -1.6337620 & 4.3020560 \\
\hline $\mathrm{H}$ & 0.7140820 & -1.0496860 & 2.6513380 \\
\hline C & -1.6644290 & -3.8277530 & -4.6055050 \\
\hline $\mathrm{H}$ & -2.9891290 & -5.3441400 & -3.7958840 \\
\hline $\mathrm{H}$ & -0.3148430 & -2.2124480 & -5.1188980 \\
\hline C & -5.0149010 & -3.2238230 & 1.9484340 \\
\hline $\mathrm{H}$ & -3.9895500 & -4.7055490 & 3.1566330 \\
\hline $\mathrm{H}$ & -5.7521570 & -1.6943200 & 0.5965390 \\
\hline C & 6.0560500 & -0.9390610 & -2.0225720 \\
\hline $\mathrm{H}$ & 6.0335180 & 0.9093560 & -0.8848100 \\
\hline $\mathrm{H}$ & 5.7945540 & -2.8507460 & -3.0142520 \\
\hline C & 3.2359640 & -2.1912710 & 4.6721700 \\
\hline $\mathrm{H}$ & 5.1018840 & -3.0470680 & 3.9683900 \\
\hline $\mathrm{H}$ & 1.3048130 & -1.2926660 & 5.0715340 \\
\hline $\mathrm{H}$ & -1.8197450 & -4.1344440 & -5.6451720 \\
\hline
\end{tabular}




\begin{tabular}{|c|c|c|c|}
\hline $\mathrm{H}$ & -5.9813080 & -3.3710850 & 2.4416810 \\
\hline $\mathrm{H}$ & 6.9980880 & -0.7111980 & -2.5320060 \\
\hline $\mathrm{H}$ & 3.4995650 & -2.2868590 & 5.7306730 \\
\hline & -1.3802150 & 0.4618440 & -0.2264780 \\
\hline & -3.1013960 & 1.6309520 & -1.5470860 \\
\hline r & -3.8289150 & 1.8563970 & 1.7688830 \\
\hline & 1.0255970 & 1.5668990 & 1.8701400 \\
\hline & -3.4595860 & 1.9614520 & -2.5281600 \\
\hline & -1.9118120 & 0.8903190 & -1.4560330 \\
\hline & 2.1711260 & 3.0547760 & 0.7977880 \\
\hline & 2.4663750 & 3.8805400 & 1.8577390 \\
\hline & 1.9560460 & 3.5170010 & 3.1382000 \\
\hline & 0.8516620 & 3.4802150 & 3.1388780 \\
\hline & 2.2952110 & 4.3058240 & 3.8232400 \\
\hline & 2.3555720 & 2.5426410 & 3.4742070 \\
\hline & 1.6484510 & 1.4607960 & -1.4668260 \\
\hline & 1.3675030 & 0.6282810 & -2.5487450 \\
\hline C & 1.8501940 & 1.0342910 & -3.8279290 \\
\hline r & 2.9532070 & 1.1043330 & -3.8439340 \\
\hline 卜 & 1.5304000 & 0.2555230 & -4.5343030 \\
\hline r & 1.4169140 & 2.0032270 & -4.1376810 \\
\hline C & 2.6474670 & 3.4315020 & -0.4688490 \\
\hline$B$ & 3.6696420 & 5.0472650 & -0.670 \\
\hline C & -3.8017190 & 1.9990890 & -0.3846080 \\
\hline C & -3.2728120 & 1.5988950 & 0.8639040 \\
\hline C & -2.0907200 & 0.8446910 & 0.9365620 \\
\hline r & -1.3744850 & 0.6515130 & -2.3795040 \\
\hline C & -5.0565400 & 2.7910530 & -0.4542520 \\
\hline C & -5.3475500 & 3.7910170 & 0.5003560 \\
\hline C & -6.0005720 & 2.5706440 & -1.4822320 \\
\hline C & -6.5318170 & 4.5349250 & 0.4335370 \\
\hline r & -4.6170630 & 4.0092130 & 1.2864970 \\
\hline C & -7.1830770 & 3.3166200 & -1.5530830 \\
\hline r & -5.8112100 & 1.7858760 & -2.2222000 \\
\hline C & -7.4572450 & 4.3022180 & -0.5938520 \\
\hline r & -6.7266350 & 5.3117650 & 1.1810460 \\
\hline $\mathrm{H}$ & -7.9002840 & 3.1202970 & -2.3576330 \\
\hline $\mathrm{H}$ & -8.3822590 & 4.8855840 & -0.6482790 \\
\hline 0 & -1.5542460 & 0.4100400 & 2.1464680 \\
\hline C & -2.2781670 & 0.7303520 & 3.3447630 \\
\hline 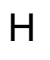 & -2.3659010 & 1.8297650 & 3.4466060 \\
\hline 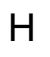 & -3.3021290 & 0.3148090 & 3.2835140 \\
\hline 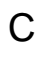 & -1.5296700 & 0.1401210 & 4.5296350 \\
\hline
\end{tabular}




\begin{tabular}{|c|c|c|c|}
\hline $\mathrm{H}$ & -0.5154740 & 0.5631750 & 4.6094050 \\
\hline $\mathrm{H}$ & -2.0673210 & 0.3673720 & 5.4650160 \\
\hline $\mathrm{H}$ & -1.4488850 & -0.9547750 & 4.4398810 \\
\hline \multicolumn{4}{|c|}{100} \\
\hline \multicolumn{4}{|c|}{$\mathrm{R}=\mathrm{OEt}$ TS } \\
\hline C & 1.1934680 & 2.0153300 & 0.8483630 \\
\hline C & 2.4130530 & 2.5164930 & -1.6041390 \\
\hline C & 0.7576290 & 1.2514260 & -0.2739340 \\
\hline $\mathrm{H}$ & 2.9296200 & 2.7134550 & -2.5450160 \\
\hline $\mathrm{Ni}$ & 0.1774460 & -0.6175990 & -0.0882160 \\
\hline$P$ & -1.0771900 & -2.4291800 & -0.0490840 \\
\hline$P$ & 1.9737310 & -1.8820890 & 0.1263740 \\
\hline C & 0.0373310 & -3.8480780 & 0.4955870 \\
\hline C & -1.6005830 & -3.0104900 & -1.7362280 \\
\hline C & -2.6240780 & -2.6478610 & 0.9380380 \\
\hline C & 1.4143350 & -3.6590370 & -0.1614080 \\
\hline C & 3.5153110 & -1.7142990 & -0.8794990 \\
\hline C & 2.6488820 & -1.9948480 & 1.8557400 \\
\hline $\mathrm{H}$ & 0.1350110 & 9510 & 1.5939580 \\
\hline $\mathrm{H}$ & -0.3991660 & -4.8280650 & 0.2385750 \\
\hline C & -2.5353720 & -4.0482710 & -1.9213000 \\
\hline C & -1.0063170 & -2.4122600 & -2.8639220 \\
\hline C & -2.7670880 & -3.5899540 & 1.9763300 \\
\hline C & -3.6982650 & -1.7737100 & 0.6612650 \\
\hline $\mathrm{H}$ & 1.3306990 & -3.8096390 & -1.2517740 \\
\hline $\mathrm{H}$ & 2.1498460 & -4.3826770 & 0.2287050 \\
\hline C & 4.2359030 & -0.5054430 & -0.7638320 \\
\hline C & 3.9732280 & -2.6916370 & -1.7856520 \\
\hline C & 3.8724440 & -2.6285090 & 2.1498280 \\
\hline C & 1.8836250 & -1.4592950 & 2.9089910 \\
\hline C & -2.8617200 & -4.4854400 & -3.2114630 \\
\hline $\mathrm{H}$ & -3.0209450 & -4.5077410 & -1.0537070 \\
\hline C & -1.3313490 & -2.8554310 & -4.1546480 \\
\hline $\mathrm{H}$ & -0.2966750 & -1.5891510 & -2.7197880 \\
\hline C & -3.9588600 & -3.6635340 & 2.7130780 \\
\hline $\mathrm{H}$ & -1.9536370 & -4.2815040 & 2.2151860 \\
\hline C & -4.8885170 & -1.8548740 & 1.3932200 \\
\hline $\mathrm{H}$ & -3.6020780 & -1.0241270 & -0.1311040 \\
\hline C & 5.3941100 & -0.2912660 & -1.5200660 \\
\hline $\mathrm{H}$ & 3.8893950 & 0.2734480 & -0.0767720 \\
\hline C & 5.1296030 & -2.4704710 & -2.5486440 \\
\hline $\mathrm{H}$ & 3.4373080 & -3.6385140 & -1.9001790 \\
\hline C & 4.3157040 & -2.7326900 & 3.4744870 \\
\hline
\end{tabular}




\begin{tabular}{|c|c|c|c|}
\hline $\mathrm{H}$ & 4.4888730 & -3.0299520 & 1.3384060 \\
\hline C & 2.3257500 & -1.5713040 & 4.2355780 \\
\hline r & 0.9436670 & -0.9454860 & 2.6762950 \\
\hline & -2.2581040 & -3.8915790 & -4.3304230 \\
\hline & -3.5934080 & -5.2895260 & -3.3447570 \\
\hline & -0.8663940 & -2.3833320 & -5.0266870 \\
\hline C & -5.0235230 & -2.8005550 & 2.4214860 \\
\hline r & -4.0558310 & -4.4061590 & 3.5125030 \\
\hline & -5.7129340 & -1.1734370 & 1.1594140 \\
\hline & 5.8454960 & -1.2733200 & 1930 \\
\hline$r$ & 5.9428050 & 0.6497860 & -1.4108830 \\
\hline & 5.4749200 & -3.2432000 & -3.2439920 \\
\hline & 3.5413810 & -2.2076230 & 4.5202710 \\
\hline & 5.2711550 & -3.2221200 & 3.6916660 \\
\hline 1 & 1.7226180 & -1.1534590 & 5.0487000 \\
\hline r & -2.5167210 & -4.2327480 & -5.3383720 \\
\hline & -5.9550450 & -2.8628330 & 2.9936080 \\
\hline & 6.75 & -1.10 & 71460 \\
\hline & 3.8902500 & -2.28 & 5.5550610 \\
\hline C & -1.0072630 & 0.9353590 & 5660 \\
\hline C & -2.8989850 & 1.8175050 & -1.6365730 \\
\hline ト & -3.6440060 & 2.0264880 & 1.6713990 \\
\hline r & 0.70 & 1.82 & 1.80 \\
\hline r & -3.2997760 & 7150 & -2.62 \\
\hline C & -1.6346310 & 1.2385170 & -1.5390300 \\
\hline C & 2.1800900 & 3.0080370 & 0.7714210 \\
\hline C & 2.6137930 & 3.7564120 & 1.8 \\
\hline C & 2.0064990 & 0530 & 5550 \\
\hline $\mathrm{H}$ & 0.9208410 & 3.7177560 & 3.0810750 \\
\hline$H$ & 2.4926740 & 4.2094110 & 3.8029110 \\
\hline $\mathrm{H}$ & 2.1780320 & 2.4750110 & 8300 \\
\hline C & 1.4365380 & 1.5210950 & -1.50 \\
\hline 0 & 1.1019150 & 0.7127750 & -2.5830570 \\
\hline C & 1.7763760 & 0.9380850 & -3.8228290 \\
\hline $\mathrm{H}$ & 2.8635790 & 0.7741680 & -3.7214370 \\
\hline $\mathrm{H}$ & 1.3630240 & 0.2023300 & -4.5257580 \\
\hline $\mathrm{H}$ & 1.5872290 & 1.9561400 & -4.2087960 \\
\hline C & 2.7789320 & 3.2637210 & -0.4762520 \\
\hline $\mathrm{Br}$ & 4.1222770 & 4.6196460 & -0.6476070 \\
\hline C & -3.6369400 & 2.1547560 & -0.4842730 \\
\hline C & -3.0538930 & 1.8463560 & 0.7700180 \\
\hline C & -1.7994880 & 1.2420080 & 0.8674080 \\
\hline $\mathrm{H}$ & -1.0847880 & 1.0273720 & -2.4568530 \\
\hline
\end{tabular}




\begin{tabular}{|c|c|c|c|}
\hline C & -4.9709230 & 2.7894230 & -0.5654490 \\
\hline C & -5.4071800 & 3.7123450 & 0.4141980 \\
\hline C & -5.8598950 & 2.4939630 & -1.6260810 \\
\hline C & -6.6716370 & 4.3075340 & 0.3399160 \\
\hline $\mathrm{H}$ & -4.7285850 & 3.9934800 & 1.2263750 \\
\hline 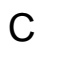 & -7.1223750 & 3.0917770 & -1.7027510 \\
\hline $\mathrm{H}$ & -5.5642500 & 1.7633260 & -2.3860680 \\
\hline $\mathrm{C}$ & -7.5385550 & 4.0014950 & -0.7190450 \\
\hline $\mathrm{H}$ & -6.9770180 & 5.0269490 & 1.1076360 \\
\hline $\mathrm{H}$ & -7.7916240 & 2.8373550 & -2.5319190 \\
\hline $\mathrm{H}$ & -8.5268590 & 4.4687380 & -0.7790060 \\
\hline 0 & -1.2617960 & 0.8475180 & 2.0828420 \\
\hline$v$ & -2.0432700 & 1.0700520 & 3.2720920 \\
\hline $\mathrm{H}$ & -2.2417850 & 2.1529460 & 3.3883210 \\
\hline $\mathrm{H}$ & -3.0153820 & 0.5530640 & 3.1716950 \\
\hline C & -1.2650680 & 0.5298510 & 4.4610660 \\
\hline $\mathrm{H}$ & -1.8404340 & 0.6912640 & 5.3875210 \\
\hline $\mathrm{H}$ & -0.2946390 & 1.0397380 & 4.5708740 \\
\hline $\mathrm{H}$ & -1.0850720 & -0.5513900 & 4.3569080 \\
\hline \multicolumn{4}{|c|}{100} \\
\hline \multicolumn{4}{|c|}{$\mathrm{R}=\mathrm{OCH} 3 \mathrm{CF} 3$ reactant } \\
\hline C & 1.5100380 & 1.8234270 & 0.8051180 \\
\hline C & 2.56 & 2.6645120 & -1.6346270 \\
\hline C & 1.27 & 1.0352260 & -0.3344480 \\
\hline $\mathrm{H}$ & 2.9879450 & 3.0214500 & -2.5763030 \\
\hline $\mathrm{Ni}$ & 0.2855210 & -0.6146590 & -0.2926960 \\
\hline$P$ & -0.8439710 & -2.5148660 & -0.4372910 \\
\hline $\mathrm{P}$ & 2.1094600 & -1.8392060 & 0.0461710 \\
\hline C & 0.2555620 & -3.8930230 & 0.2152210 \\
\hline C & -1.0795000 & -3.0347700 & -2.2021940 \\
\hline C & -2.5026420 & -2.8152780 & 0.3104760 \\
\hline C & 1.6762410 & -3.6365810 & -0.3080340 \\
\hline C & 3.7067660 & -1.5456340 & -0.8294530 \\
\hline C & 2.6238330 & -1.9258910 & 1.8245760 \\
\hline $\mathrm{H}$ & 0.2439050 & -3.8443330 & 1.3176140 \\
\hline $\mathrm{H}$ & -0.1188080 & -4.8841530 & -0.0905140 \\
\hline C & -1.9070590 & -4.1204610 & -2.5512470 \\
\hline C & -0.3664950 & -2.3567530 & -3.2094160 \\
\hline C & -2.7046360 & -3.7046310 & 1.3834430 \\
\hline C & -3.6030930 & -2.0899230 & -0.1945340 \\
\hline $\mathrm{H}$ & 1.7030090 & -3.7853190 & -1.4008160 \\
\hline $\mathrm{H}$ & 2.4109830 & -4.3188490 & 0.1502560 \\
\hline C & 4.4132790 & -0.3587560 & -0.5400780 \\
\hline
\end{tabular}




\begin{tabular}{|c|c|c|c|}
\hline $\mathrm{C}$ & 4.2304200 & -2.4354220 & -1.7872500 \\
\hline C & 3.8659930 & -2.4679160 & 2.2108600 \\
\hline C & 1.7234220 & -1.4891520 & 2.8135520 \\
\hline C & -2.0126860 & -4.5262060 & -3.8874050 \\
\hline $\mathrm{H}$ & -2.4825090 & -4.6416510 & -1.7788500 \\
\hline C & -0.4731630 & -2.7693330 & -4.5462400 \\
\hline $\mathrm{H}$ & 0.2627280 & -1.4996250 & -2.9414120 \\
\hline C & -3.9828230 & -3.8735150 & 1.9351260 \\
\hline $\mathrm{H}$ & -1.8695830 & -4.2743290 & 1.8008940 \\
\hline C & -4.8775460 & -2.2637460 & 0.3582820 \\
\hline $\mathrm{H}$ & -3.4626870 & -1.3856990 & -1.0201160 \\
\hline C & 5.6217600 & -0.0788200 & -1.1889210 \\
\hline $\mathrm{H}$ & 4.0170840 & 0.3491070 & 0.1939270 \\
\hline C & 5.4406020 & -2.1496850 & -2.4360390 \\
\hline $\mathrm{H}$ & 3.7055310 & -3.3624250 & -2.0347560 \\
\hline C & 4.1958050 & -2.5768540 & 3.5672990 \\
\hline $\mathrm{H}$ & 4.5832340 & -2.7921510 & 1.4496760 \\
\hline 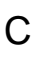 & 2.0554650 & -1.6032580 & 4.1717140 \\
\hline $\mathrm{H}$ & 0.7646700 & -1.05 & 2.5136 \\
\hline C & -1.2942130 & -3.8522110 & -4.8866830 \\
\hline r & -2.6619920 & -5.3678460 & -4.1506360 \\
\hline F & 0.0809440 & -2.2364870 & -5.3260050 \\
\hline 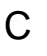 & -5.0717720 & -3.1563840 & $1.422 \varepsilon$ \\
\hline $\mathrm{H}$ & -4.1244790 & -4.5702230 & 2.7678510 \\
\hline $\mathrm{H}$ & -5.7214760 & -1.6948100 & -0.0445960 \\
\hline C & 6.1395750 & -0.9728620 & -2.1372430 \\
\hline П & 6.1567770 & 0.8464 & -0.953 \\
\hline $\mathrm{H}$ & 5.8380980 & -2.85 & -3.173 \\
\hline C & 3.2904910 & -2.1461060 & 4.5492050 \\
\hline $\mathrm{H}$ & 5.1654610 & -2.9939650 & 3.8589660 \\
\hline $\mathrm{H}$ & 1.3490260 & -1.2584850 & 4.9323630 \\
\hline $\mathrm{H}$ & -1.3809790 & -4.1685740 & -5.9313990 \\
\hline $\mathrm{H}$ & -6.0696350 & -3.2908320 & 1.8530600 \\
\hline $\mathrm{H}$ & 7.0856640 & -0.7520870 & -2.6422610 \\
\hline $\mathrm{H}$ & 3.5522950 & -2.2288130 & 5.6092320 \\
\hline C & -1.2756770 & 0.4803490 & -0.5331430 \\
\hline C & -2.8684830 & 1.6693420 & -1.9953630 \\
\hline $\mathrm{H}$ & -3.9036750 & 1.8689420 & 1.2356140 \\
\hline $\mathrm{H}$ & 1.0825670 & 1.5080560 & 1.7601940 \\
\hline $\mathrm{H}$ & -3.1344270 & 2.0079860 & -3.0026410 \\
\hline C & -1.6951910 & 0.9239670 & -1.8023910 \\
\hline C & 2.2726600 & 3.0114260 & 0.7642650 \\
\hline $\mathrm{O}$ & 2.5425310 & 3.8034020 & 1.8545660 \\
\hline
\end{tabular}




\begin{tabular}{|c|c|c|c|}
\hline C & 2.0005470 & 3.4026570 & 3.1123460 \\
\hline $\mathrm{H}$ & 0.8964910 & 3.3795220 & 3.0893370 \\
\hline 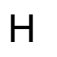 & 2.3346310 & 4.1637580 & 3.8301950 \\
\hline $\mathrm{H}$ & 2.3803260 & 2.4126720 & 3.4226210 \\
\hline C & 1.8126440 & 1.4818770 & -1.5586810 \\
\hline 0 & 1.5641160 & 0.6784510 & -2.6703050 \\
\hline $\mathrm{C}$ & 2.1004550 & 1.1086810 & -3.9200770 \\
\hline $\mathrm{H}$ & 3.2037890 & 1.1664440 & -3.8916210 \\
\hline $\mathrm{H}$ & 1.8002400 & 0.3503950 & -4.6566500 \\
\hline $\mathrm{H}$ & 1.6897690 & 2.0894920 & -4.2232230 \\
\hline C & 2.7946170 & 3.4159180 & -0.4758760 \\
\hline $\mathrm{Br}$ & 3.8390010 & 5.0248040 & -0.5999710 \\
\hline C & -3.6745050 & 2.0310900 & 15020 \\
\hline C & -3.2635420 & 1.6165090 & 0.3856690 \\
\hline C & -2.0960070 & 0.8581310 & 0.5523760 \\
\hline $\mathrm{H}$ & -1.0759360 & 0.6922670 & -2.6743490 \\
\hline C & -4.9158480 & 2.8270340 & 9550 \\
\hline C & -5.2858700 & 3.8258710 & -0.1512440 \\
\hline C & -5.7659970 & 2.6103530 & -2.1862590 \\
\hline C & -6.4579500 & 4.5729370 & -0.3197980 \\
\hline $\mathrm{H}$ & -4.6257810 & 4.0424360 & 4050 \\
\hline C & -6.9360100 & 3.35 & -2.3 \\
\hline $\mathrm{H}$ & -5.5145340 & 1.8263440 & -2.90 \\
\hline C & -7.2902910 & 4.3438770 & -1.4245860 \\
\hline $\mathrm{H}$ & -6.7154360 & 5.3490880 & 0.4090440 \\
\hline $\mathrm{H}$ & -7.5807930 & 3.16 & -3.22 \\
\hline $\mathrm{H}$ & -8.2056120 & 4.9295650 & -1.55 \\
\hline 0 & -1.6765000 & 0.4072490 & 1.8149660 \\
\hline C & -2.5436020 & 0.6774000 & 2.8979790 \\
\hline $\mathrm{H}$ & -2.6766130 & 1.7629230 & 3.06 \\
\hline $\mathrm{H}$ & -3.5386030 & 0.2148870 & 5760 \\
\hline C & -1.9377250 & 0.0952610 & 4.1671030 \\
\hline$\vdash$ & -2.7793540 & 0.3356840 & 5.2173210 \\
\hline $\mathrm{F}$ & -1.7457320 & -1.2490480 & 4.0990530 \\
\hline $\mathrm{F}$ & -0.7338440 & 0.657 & 4.4781890 \\
\hline \multicolumn{4}{|c|}{100} \\
\hline \multicolumn{4}{|c|}{$\mathrm{R}=\mathrm{OCH} 3 \mathrm{CF} 3 \mathrm{TS}$} \\
\hline C & 1.1845660 & 2.0611620 & 0.5979940 \\
\hline C & 2.5615800 & 2.4396440 & -1.7942510 \\
\hline C & 0.8271920 & 1.2370350 & -0.5094440 \\
\hline $\mathrm{H}$ & 3.1384600 & 2.5899860 & -2.7082260 \\
\hline $\mathrm{Ni}$ & 0.2659830 & -0.6342880 & -0.2558780 \\
\hline$P$ & -0.9825710 & -2.4441010 & -0.1452370 \\
\hline
\end{tabular}




$\begin{array}{lrrr}\text { P } & 2.0697560 & -1.8818620 & 0.0574260 \\ \mathrm{C} & 0.1201230 & -3.8161170 & 0.5236070 \\ \mathrm{C} & -1.4485960 & -3.1355190 & -1.8069530 \\ \mathrm{C} & -2.5610540 & -2.5984520 & 0.8023300 \\ \mathrm{C} & 1.5057910 & -3.6718490 & -0.1272700 \\ \mathrm{C} & 3.6012220 & -1.7691480 & -0.9723840 \\ \mathrm{C} & 2.7656380 & -1.9027950 & 1.7806230 \\ \mathrm{H} & 0.2013960 & -3.6808360 & 1.6162400 \\ \mathrm{H} & -0.3126350 & -4.8126830 & 0.3326060 \\ \mathrm{C} & -2.3703210 & -4.1908900 & -1.9549720 \\ \mathrm{C} & -0.8204820 & -2.6072200 & -2.9510850 \\ \mathrm{C} & -2.7157010 & -3.4207910 & 1.9360060 \\ \mathrm{C} & -3.6463490 & -1.7905250 & 0.3963540 \\ \mathrm{H} & 1.4334670 & -3.8935070 & -1.2061550 \\ \mathrm{H} & 2.2358800 & -4.3690200 & 0.3168780 \\ \mathrm{C} & 4.3560370 & -0.5789490 & -0.8843990 \\ \mathrm{C} & 4.0208410 & -2.7710540 & -1.8699550 \\ \mathrm{C} & 4.0021070 & -2.5053570 & 2.0878150 \\ \mathrm{C} & 2.0038050 & -1.3336330 & 2.8178290 \\ \mathrm{C} & -2.6514880 & -4.7123910 & -3.2242120 \\ \mathrm{H} & -2.8805010 & -4.5986050 & -1.0757530 \\ \mathrm{C} & -1.0998880 & -3.1347740 & -4.2205850 \\ \mathrm{H} & -0.1190290 & -1.7725690 & -2.8370270 \\ \mathrm{C} & -3.9282220 & -3.4426450 & 2.6410150 \\ \mathrm{H} & -1.8928830 & -4.0547870 & 2.2789770 \\ \mathrm{C} & -4.8579180 & -1.8210160 & 1.0972540 \\ \mathrm{H} & -3.5436540 & -1.1348150 & -0.4746140 \\ \mathrm{C} & 5.5094190 & -0.4069990 & -1.6585890 \\ \mathrm{H} & 4.0420550 & 0.2175840 & -0.2020550 \\ \mathrm{C} & 5.1727040 & -2.5925470 & -2.6509050 \\ \mathrm{H} & 3.4593990 & -3.7052650 & -1.9632260 \\ \mathrm{C} & 4.4619140 & -2.5414710 & 3.4101810 \\ \mathrm{H} & 4.6148200 & -2.9360680 & 1.2888310 \\ \mathrm{C} & 2.4619810 & -1.3780530 & 4.1429090 \\ \mathrm{H} & 1.0504870 & -0.8509940 & 2.5785760 \\ \mathrm{C} & -2.0148910 & -4.1868420 & -4.3590250 \\ \mathrm{H} & -3.3731330 & -5.5296080 & -3.3290310 \\ \mathrm{H} & -0.6081110 & -2.7167450 & -5.1053780 \\ \mathrm{C} & -5.0033130 & -2.6475370 & 2.2224940 \\ \mathrm{H} & -4.0317410 & -4.0895690 & 3.5186350 \\ \mathrm{H} & -5.6913950 & -1.1953090 & 0.7614860 \\ \mathrm{C} & 5.9226380 & -1.4137730 & -2.5447800 \\ \mathrm{H} & 6.0861140 & 0.5192710 & -1.5686910\end{array}$




\begin{tabular}{|c|c|c|c|}
\hline $\mathrm{H}$ & 5.4882080 & -3.3851380 & -3.3379700 \\
\hline C & 3.6914320 & -1.9803750 & 4.4402390 \\
\hline r & 5.4271500 & -3.0064470 & 3.6376740 \\
\hline $\mathrm{H}$ & 1.8589330 & -0.9341030 & 4.9411290 \\
\hline $\mathrm{H}$ & -2.2381120 & -4.5943930 & -5.3506160 \\
\hline r & -5.9506750 & -2.6697050 & 2.7709180 \\
\hline r & 6.8254010 & -1.2789830 & -3.1495050 \\
\hline ⺊ & 4.0538290 & -2.0084600 & 5.4732070 \\
\hline & -0.9173820 & 0.8865100 & -0.6257400 \\
\hline $\mathrm{C}$ & -2.7312610 & 1.6350550 & -2.1514470 \\
\hline r & -3.7238360 & 2.0278850 & 1.0687490 \\
\hline$\vdash$ & 0.6407020 & 1.9189130 & 1.5311490 \\
\hline 卜 & -3.06 & 1.7896490 & -3.1833670 \\
\hline C & -1.4664540 & 1.0957880 & -1.9275680 \\
\hline C & 2.1747970 & 3.0522740 & 0.5343360 \\
\hline $\mathrm{C}$ & 2.5396370 & 3.8562790 & 1.5846650 \\
\hline C & 1.8604360 & 3.6727120 & 2.8271350 \\
\hline 卜 & 0.7792250 & 3.8758830 & 2.7301890 \\
\hline ⺊ & 2.3085160 & 4.4019170 & 3.5150150 \\
\hline $\mathrm{H}$ & 2.0083690 & 2.6528240 & 3.2225990 \\
\hline C & 1.5832940 & 1.4449920 & -1.7115130 \\
\hline O & 1.3239850 & 0.57 & -2.7595290 \\
\hline C & 2.0683660 & 0.75 & -3.9683170 \\
\hline $\mathrm{H}$ & 3.1481730 & 0.5984990 & -3.7967610 \\
\hline $\mathrm{H}$ & 1.6990200 & -0.0202710 & -4.6577300 \\
\hline $\mathrm{H}$ & 1.8968630 & 1.748 & -4.4115750 \\
\hline C & 2.8514090 & 3.2452010 & -0.6852170 \\
\hline $\mathrm{Br}$ & 4.1979920 & 4.5982660 & -0.8405030 \\
\hline C & -3.5607700 & 2.0267840 & -1.0816430 \\
\hline C & -3.0610760 & 1.8108660 & 0.2272320 \\
\hline C & -1.8050700 & 140 & 0.4466150 \\
\hline $\mathrm{H}$ & -0.8498880 & 0.8393090 & -2.7891970 \\
\hline C & -4.8987770 & 2.6182950 & -1.2962310 \\
\hline C & -5.4256190 & 3.5873660 & -0.4100190 \\
\hline C & -5.7015750 & 5400 & -2.3963180 \\
\hline C & -6.6954010 & 4.1406420 & -0.6100430 \\
\hline $\mathrm{H}$ & -4.8136440 & 3.9390890 & 0.4273300 \\
\hline C & -6.9689690 & 2.7898050 & -2.5987770 \\
\hline $\mathrm{H}$ & -5.3354610 & 1.4658980 & -3.0858370 \\
\hline C & -7.4762890 & 3.7456710 & -1.7057900 \\
\hline $\mathrm{H}$ & -7.0720440 & 4.8969880 & 0.0871540 \\
\hline $\mathrm{H}$ & -7.5707890 & 2.4663260 & -3.4550270 \\
\hline $\mathrm{H}$ & -8.4686040 & 4.1800820 & -1.8641720 \\
\hline
\end{tabular}




\begin{tabular}{|c|c|c|c|}
\hline $\mathrm{O}$ & -1.3526850 & 0.9439090 & 1.7345860 \\
\hline C & -2.2725730 & 1.1304960 & 2.7956870 \\
\hline 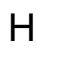 & -2.5718960 & 2.1894870 & 2.9076100 \\
\hline$H$ & -3.1777020 & 0.5105450 & 2.6595390 \\
\hline C & -1.6054240 & 0.7113770 & 4.0987480 \\
\hline 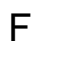 & -0.4987140 & 1.4578350 & 4.3810100 \\
\hline$F$ & -1.2238510 & -0.5918520 & 4.1075300 \\
\hline$F$ & -2.4879170 & 0.8891210 & 5.1264720 \\
\hline \multicolumn{4}{|l|}{96} \\
\hline \multicolumn{4}{|c|}{$\mathrm{R}=$ Me reactant } \\
\hline C & 1.5388370 & 1.7893350 & 1.0800580 \\
\hline C & 2.2498850 & 2.6981490 & -1.4533470 \\
\hline C & 1.1093000 & 1.0470300 & -0.0350070 \\
\hline $\mathrm{H}$ & 2.5412050 & 3.0789380 & -2.4341400 \\
\hline $\mathrm{Ni}$ & 0.1099540 & -0.5951700 & 0.0703040 \\
\hline $\mathrm{P}$ & -1.0565830 & -2.4773420 & -0.0464390 \\
\hline$P$ & 1.9450490 & -1.8599020 & 0.1704720 \\
\hline C & 0.0868410 & -3.9043920 & 0.3979880 \\
\hline C & -1.5009850 & -2.8993140 & -1.7973460 \\
\hline C & -2.6190910 & -2.8125840 & 0.8753520 \\
\hline C & 1.4528830 & -3.6282740 & -0.2453230 \\
\hline$\checkmark$ & 3.4740600 & -1.5471570 & -0.8140400 \\
\hline C & 2.5980000 & -2.0557880 & 1.8974410 \\
\hline $\mathrm{H}$ & 0.1863100 & -3.9319280 & 1.4967210 \\
\hline $\mathrm{H}$ & -0.3312770 & -4.8693880 & 0.0664120 \\
\hline $\mathrm{C}$ & -2.4036080 & -3.9372760 & -2.1021230 \\
\hline C & -0.8715840 & -2.1994770 & -2.8444750 \\
\hline C & -2.7153250 & -3.7919630 & 1.8840320 \\
\hline C & -3.7497610 & -2.0211390 & 0.5787930 \\
\hline $\mathrm{H}$ & 1.3699250 & -3.7045000 & -1.3430000 \\
\hline $\mathrm{H}$ & 2.2171340 & -4.3471100 & 0.0936150 \\
\hline C & 4.1933960 & -0.3581570 & -0.5672540 \\
\hline C & 3.9320480 & -2.4264840 & -1.8146560 \\
\hline C & 3.8759400 & -2.5881870 & 2.1587900 \\
\hline C & 1.7651180 & -1.7094360 & 2.9779750 \\
\hline C & -2.6656970 & -4.2752850 & -3.4356770 \\
\hline $\mathrm{H}$ & -2.9149310 & -4.4734960 & -1.2957380 \\
\hline C & -1.1342750 & -2.5454210 & -4.1785950 \\
\hline $\mathrm{H}$ & -0.1863660 & -1.3765590 & -2.6089000 \\
\hline C & -3.9190380 & -3.9805710 & 2.5784310 \\
\hline $\mathrm{H}$ & -1.8562620 & -4.4204950 & 2.1361870 \\
\hline C & -4.9492730 & -2.2156770 & 1.2737210 \\
\hline $\mathrm{H}$ & -3.6900690 & -1.2468540 & -0.1916780 \\
\hline
\end{tabular}




\begin{tabular}{|c|c|c|c|}
\hline C & 5.3499490 & -0.0661040 & -1.3000550 \\
\hline $\mathrm{H}$ & 3.8462490 & 0.3433020 & 0.1972110 \\
\hline C & 5.0896290 & -2.1278990 & -2.5480730 \\
\hline $\mathrm{H}$ & 3.3961040 & -3.3550960 & -2.0303490 \\
\hline C & 4.3057380 & -2.7772000 & 3.4785530 \\
\hline r & 4.5428330 & -2.8429720 & 1.3286870 \\
\hline $\mathrm{C}$ & 2.1952810 & -1.9041490 & 4.2985540 \\
\hline ト & 0.7791050 & -1.2767040 & 2.7761500 \\
\hline $\mathrm{C}$ & -2.0293940 & -3.5813100 & -4.4759230 \\
\hline $\mathrm{H}$ & -3.3730650 & -5.0795220 & -3.6638860 \\
\hline $\mathrm{H}$ & -0.6444220 & -1.9965460 & -4.9896690 \\
\hline $\mathrm{C}$ & -5.0379560 & -3.1943130 & 2.2741970 \\
\hline $\mathrm{H}$ & -3.9798320 & -4.7479410 & 3.3573150 \\
\hline $\mathrm{H}$ & -5.8159960 & -1.5913030 & 1.0354400 \\
\hline C & 5.8018610 & -0.9491420 & -2.2913440 \\
\hline $\mathrm{H}$ & 5.8949020 & 0.8611220 & -1.0972290 \\
\hline $\mathrm{H}$ & 5.4355810 & -2.8239790 & -3.3194990 \\
\hline$C$ & 3.4660900 & -2.4379750 & 4.5502530 \\
\hline $\mathrm{H}$ & 5.3029940 & -3.1865290 & 3.6713020 \\
\hline $\mathrm{H}$ & 1.5386420 & -1.6304730 & 5.1310200 \\
\hline $\mathrm{H}$ & -2.2381820 & -3.8446000 & -5.5180960 \\
\hline$H$ & -5.9770250 & -3.3418000 & 2.8174430 \\
\hline $\mathrm{H}$ & 6.7064120 & -0.7177490 & -2.8632710 \\
\hline $\mathrm{H}$ & 3.8062250 & -2.5843050 & 5.5806580 \\
\hline C & -1.4659940 & 0.5201340 & 0.0802930 \\
\hline C & -3.3226550 & 1.6314640 & 1.2210330 \\
\hline $\mathrm{H}$ & -3.5556150 & 2.1160090 & -2.1437430 \\
\hline $\mathrm{H}$ & 1.2708570 & 1.4421080 & 2.0811740 \\
\hline $\mathrm{H}$ & -3.8493760 & 1.8545100 & 2.1575920 \\
\hline C & -2.1496870 & 0.8579940 & 1.2788370 \\
\hline $\mathrm{C}$ & 2.3119650 & 2.9660620 & 0.9702830 \\
\hline $\mathrm{O}$ & 2.7545320 & 3.7117200 & 2.0373640 \\
\hline $\mathrm{C}$ & 2.3566120 & 3.2998610 & 3.3434970 \\
\hline $\mathrm{H}$ & 1.2569360 & 3.3015190 & 3.4514320 \\
\hline $\mathrm{H}$ & 2.7910040 & 4.0402130 & 4.0286420 \\
\hline $\mathrm{H}$ & 2.7491570 & 2.2970060 & 3.5927500 \\
\hline C & 1.4868230 & 1.5282020 & -1.3079800 \\
\hline $\mathrm{O}$ & 1.0735950 & 0.7672620 & -2.4001200 \\
\hline C & 1.4225060 & 1.2424470 & -3.6990320 \\
\hline $\mathrm{H}$ & 2.5183840 & 1.2901480 & -3.8352800 \\
\hline $\mathrm{H}$ & 1.0042930 & 0.5164940 & -4.4102020 \\
\hline $\mathrm{H}$ & 0.9845150 & 2.2376240 & -3.8990960 \\
\hline C & 2.6584020 & 3.4065290 & -0.3173430 \\
\hline
\end{tabular}




$\begin{array}{llll}\mathrm{C} & -3.8722850 & 2.0883060 & 0.0057880 \\ \mathrm{C} & -3.1871640 & 1.7500750 & -1.1782930 \\ \mathrm{C} & -2.0073260 & 0.9954240 & -1.1332750 \\ \mathrm{C} & -5.1196430 & 2.8939280 & -0.0215020 \\ \mathrm{C} & -6.0740760 & 2.7271970 & -1.0499150 \\ \mathrm{C} & -5.3930370 & 3.8541250 & 0.9781290 \\ \mathrm{C} & -7.2504580 & 3.4857910 & -1.0778250 \\ \mathrm{H} & -5.8990690 & 1.9738510 & -1.8253530 \\ \mathrm{C} & -6.5708560 & 4.6105480 & 0.9540490 \\ \mathrm{H} & -4.6553750 & 4.0285860 & 1.7683190 \\ \mathrm{C} & -7.5070940 & 4.4311310 & -0.0743480 \\ \mathrm{H} & -7.9763670 & 3.3309500 & -1.8836510 \\ \mathrm{H} & -6.7525960 & 5.3550000 & 1.7369550 \\ \mathrm{H} & -8.4271490 & 5.0244660 & -0.0950640 \\ \mathrm{C} & -1.6584210 & 0.3775720 & 2.6270990 \\ \mathrm{H} & -1.6264570 & -0.7261650 & 2.6723500 \\ \mathrm{H} & -0.6383470 & 0.7416720 & 2.8381050 \\ \mathrm{H} & -2.3107330 & 0.7224170 & 3.4465380 \\ \mathrm{H} & -1.4867730 & 0.7869000 & -2.0730510 \\ \mathrm{Br} & 3.7067700 & 5.0018560 & -0.5391560 \\ 96 & & & \\ \mathrm{R}=\mathrm{Me} \mathrm{TS} & & \\ \mathrm{C} & -1.1720230 & 2.0744470 & -1.0589970 \\ \mathrm{C} & -2.3470630 & 2.5547570 & 1.4133320 \\ \mathrm{C} & -0.7151710 & 1.2943130 & 0.0433050 \\ \mathrm{H} & -2.8417800 & 2.7464180 & 2.3668560 \\ \mathrm{Ni} & -0.1277280 & -0.5898430 & -0.0379100 \\ \mathrm{P} & 1.1540550 & -2.3810000 & 0.1740670 \\ \mathrm{P} & -1.9076640 & -1.8966270 & -0.1897430 \\ \mathrm{C} & 0.0568940 & -3.8753710 & -0.1663180 \\ \mathrm{C} & 1.7308600 & -2.7437210 & 1.9044680 \\ \mathrm{C} & 2.6834120 & -2.6915340 & -0.8177480 \\ \mathrm{C} & -1.3417470 & -3.5947470 & 0.4065910 \\ \mathrm{C} & -3.4756960 & -1.5858240 & 0.7367780 \\ \mathrm{C} & -2.5317670 & -2.3151090 & -1.8945970 \\ \mathrm{H} & -0.0090620 & -4.0059670 & -1.2604240 \\ \mathrm{H} & 0.4884390 & -4.7969090 & 0.2592970 \\ \mathrm{C} & 2.6739800 & -3.7520320 & 2.1861600 \\ \mathrm{C} & 1.1755270 & -2.0057350 & 2.9664970 \\ \mathrm{C} & 2.8325380 & -3.7592260 & -1.7255040 \\ \mathrm{C} & 3.7338700 & -1.7561040 & -0.6901520 \\ \mathrm{H} & -1.2973310 & -3.5579100 & 1.5092340 \\ \mathrm{H} & -2.0574910 & -4.3828550 & 0.1177560\end{array}$




\begin{tabular}{|c|c|c|c|}
\hline $\mathrm{C}$ & -4.1380530 & -0.3623410 & 0.4980920 \\
\hline C & -4.0168160 & -2.4753110 & 1.6866780 \\
\hline $\mathrm{C}$ & -3.8539770 & -2.7356430 & -2.1403390 \\
\hline C & -1.6319070 & -2.2406000 & -2.9768220 \\
\hline C & 3.0462420 & -4.0231350 & 3.5088700 \\
\hline $\mathrm{H}$ & 3.1304930 & -4.3187320 & 1.3675300 \\
\hline C & 1.5478300 & -2.2821990 & 4.2907610 \\
\hline $\mathrm{H}$ & 0.4607010 & -1.2061050 & 2.7427250 \\
\hline C & 4.0058530 & -3.8913530 & -2.4834850 \\
\hline $\mathrm{H}$ & 2.0392760 & -4.5031510 & -1.8452550 \\
\hline C & 4.9056470 & -1.8953340 & -1.4423190 \\
\hline $\mathrm{H}$ & 3.6312750 & -0.9098260 & -0.0030310 \\
\hline 乙 & -5.3215380 & -0.0480650 & 1.1771000 \\
\hline $\mathrm{H}$ & -3.7249030 & 0.3501090 & -0.2233270 \\
\hline C & -5.1966450 & -2.1530940 & 2.37 \\
\hline $\mathrm{H}$ & -3.5283090 & -3.4320280 & 1.8934640 \\
\hline C & -4.2621050 & -3.0763710 & -3.4370920 \\
\hline $\mathrm{H}$ & -4.5720090 & -2.7878540 & -1.3160360 \\
\hline C & -2.03 & -2.5930590 & -4.27 \\
\hline $\mathrm{H}$ & -0.6070740 & -1.8955310 & -2.8025620 \\
\hline C & 2.4817100 & -3.2901810 & 4.5640030 \\
\hline $\mathrm{H}$ & 3.7836810 & -4.8057100 & 3.7172010 \\
\hline $\mathrm{H}$ & 1.115 & -1.7012500 & 5.11 \\
\hline C & 5.0453630 & -2.9626870 & -2.34 \\
\hline $\mathrm{H}$ & 4.1075150 & -4.7292600 & -3.1815870 \\
\hline $\mathrm{H}$ & 5.7100050 & -1.1615350 & -1.3283900 \\
\hline C & -5.854 & -0.9423140 & 2.11 \\
\hline $\mathrm{H}$ & -5.8225 & 0.903 & 0.97 \\
\hline $\mathrm{H}$ & -5.6061470 & -2.8573290 & 3.1059990 \\
\hline C & -3.3555580 & -3.0098470 & -4.5048970 \\
\hline $\mathrm{H}$ & -5.2950830 & -3.3948470 & -3.6136520 \\
\hline $\mathrm{H}$ & -1.3252280 & -2.5310420 & -5.1006780 \\
\hline $\mathrm{H}$ & 2.7767610 & -3.5009500 & 5.5973010 \\
\hline $\mathrm{H}$ & 5.9610460 & -3.0681390 & -2.9336200 \\
\hline $\mathrm{H}$ & -6.7780510 & -0.6944550 & 2.6509660 \\
\hline $\mathrm{H}$ & -3.6774770 & -3.2761160 & -5.5170000 \\
\hline C & 1.0517000 & 0.9996020 & 0.0119030 \\
\hline C & 3.0356830 & 1.7937230 & -1.2012820 \\
\hline $\mathrm{H}$ & 3.3861720 & 2.3967380 & 2.1335170 \\
\hline $\mathrm{H}$ & -0.6982310 & 1.9232540 & -2.0280720 \\
\hline $\mathrm{H}$ & 3.5831490 & 1.8639020 & -2.1500670 \\
\hline C & 1.7827890 & 1.1721700 & -1.2154360 \\
\hline C & -2.1624510 & 3.0611540 & -0.9611470 \\
\hline
\end{tabular}




\begin{tabular}{|c|c|c|c|}
\hline $\mathrm{O}$ & -2.6116250 & 3.8183810 & -2.0153570 \\
\hline C & -2.0052440 & 3.6094730 & -3.2899080 \\
\hline $\mathrm{H}$ & -0.9231200 & 3.8312910 & -3.2646700 \\
\hline $\mathrm{H}$ & -2.5049470 & 4.3121350 & -3.9698370 \\
\hline $\mathrm{H}$ & -2.1623440 & 2.5765160 & -3.6502190 \\
\hline C & -1.3669560 & 1.5649700 & 1.2929950 \\
\hline 0 & -0.9976650 & 0.7641840 & 2.3636020 \\
\hline C & -1.6635310 & 0.9713450 & 3.6116350 \\
\hline $\mathrm{H}$ & -2.7497630 & 0.7976230 & 1120 \\
\hline $\mathrm{H}$ & -1.2370770 & 0.2330290 & 4.3040720 \\
\hline r & -1.4808470 & 1.9873890 & 4.0060370 \\
\hline & -2.7424180 & 3.3045330 & 0.2984440 \\
\hline C & 3550 & 2.2567760 & -0.0215650 \\
\hline C & 2.9577960 & 2.0471710 & 1.1876420 \\
\hline C & 1.7030450 & 1.4463160 & 1.2004640 \\
\hline C & 4.9880310 & 2.9076910 & -0.0529800 \\
\hline C & 5.9095130 & 2.7470880 & 1.0085070 \\
\hline C & 5.3852100 & 3.7112590 & -1.1473780 \\
\hline $\mathrm{C}$ & 7.1670670 & 3.3596570 & 8150 \\
\hline $\mathrm{H}$ & 5.6442360 & 2.1098770 & 1.8585660 \\
\hline$u$ & 6.6444250 & 4.3208420 & -1.1813230 \\
\hline $\mathrm{H}$ & 4.6817270 & 3.8848000 & -1.9682620 \\
\hline C & 7.5443140 & 4.1495160 & -0.1193840 \\
\hline $\mathrm{H}$ & 7.8624400 & 3.2108510 & 1.8101460 \\
\hline $\mathrm{H}$ & 6.9202270 & 4.9455920 & -2.0379120 \\
\hline $\mathrm{H}$ & 8.5284530 & 4.6286260 & 12800 \\
\hline $\mathrm{H}$ & 1.1857600 & 1.3353730 & 50790 \\
\hline C & 1.2995030 & 0.5977400 & -2.5343130 \\
\hline $\mathrm{H}$ & 1.2326440 & 1.3638490 & -3.3284810 \\
\hline 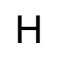 & 2.0003450 & -0.1756710 & -2.8946980 \\
\hline $\mathrm{H}$ & 0.3145800 & 0.1138210 & -2.4348510 \\
\hline $\mathrm{Br}$ & -4.0863150 & 4.6541680 & 0.5026960 \\
\hline \multicolumn{4}{|c|}{77} \\
\hline \multicolumn{4}{|c|}{$\mathrm{Ar}=$ ethene reactant } \\
\hline $\mathrm{Ni}$ & -0.6123520 & -0.2230320 & -0.4557080 \\
\hline $\mathrm{P}$ & -2.7639850 & -0.1915200 & -0.0035540 \\
\hline$P$ & -0.2775100 & 0.7935790 & 1.4909990 \\
\hline C & -3.0487420 & 0.7899210 & 1.5819240 \\
\hline C & -3.4182050 & -1.8618930 & 0.4575030 \\
\hline C & -4.0187790 & 0.4690350 & -1.1862580 \\
\hline C & 1.2535420 & -0.4409320 & -0.8686010 \\
\hline C & -1.8439560 & 0.5758730 & 2.5090330 \\
\hline C & -0.1896690 & 2.6397820 & 1.3135570 \\
\hline
\end{tabular}




\begin{tabular}{|c|c|c|c|}
\hline C & 1.1028910 & 0.4269620 & 2.6580570 \\
\hline $\mathrm{H}$ & -3.9945020 & 0.4925620 & 2.0635300 \\
\hline $\mathrm{H}$ & -3.1305420 & 1.8563020 & 1.3154530 \\
\hline $\mathrm{C}$ & -4.7710860 & -2.0600870 & 0.8008920 \\
\hline C & -2.5248790 & -2.9478740 & 0.5131250 \\
\hline $\mathrm{C}$ & -4.5755010 & -0.3858760 & -2.1595900 \\
\hline C & -4.3468440 & 1.8394000 & -1.2204530 \\
\hline C & 1.9244570 & -1.5767540 & -0.3690810 \\
\hline C & 2.0078900 & 0.4739000 & -1.6232730 \\
\hline r & -1.8689720 & 1.2654460 & 3.3695640 \\
\hline $\mathrm{H}$ & -1.8410480 & -0.4575900 & 2.8965510 \\
\hline C & 0.1421410 & 3.4841790 & 2.3912600 \\
\hline $\mathrm{C}$ & -0.5006760 & 3.2101180 & 0.0646720 \\
\hline C & 2.4238470 & 0.6303820 & 3270 \\
\hline C & 0.8955790 & -0.0719230 & 3.9588170 \\
\hline $\mathrm{C}$ & -5.2217690 & -3.3260610 & 1.1938650 \\
\hline $\mathrm{H}$ & -5.4805040 & -1.2273150 & 0.7443980 \\
\hline C & -2.9809970 & -4.2147840 & 3410 \\
\hline 卜 & -1.4740860 & -2.79 & 370 \\
\hline C & -5.4654450 & 0.1137060 & -3.1189030 \\
\hline $\mathrm{H}$ & -4.3139290 & -1.4472500 & -2.1655380 \\
\hline C & -5.2365310 & 2.3361990 & -2.1825560 \\
\hline r & -3.9094470 & 2.5365 & -0.4993060 \\
\hline C & 3.2963410 & -1.7762400 & -0.5980190 \\
\hline 0 & 1.1462130 & -2.4713720 & 0.3633500 \\
\hline $\mathrm{C}$ & 3.3877030 & 0.3067290 & -1.86 \\
\hline $\mathrm{H}$ & 1.5013800 & 1.342 & -2.05 \\
\hline C & 0.1505680 & 4.874 & 2.2222820 \\
\hline $\mathrm{H}$ & 0.4114780 & 3.0531700 & 3.3614370 \\
\hline C & -0.4937740 & 4.6027460 & -0.1024510 \\
\hline $\mathrm{H}$ & -0.7377050 & 2.5489360 & -0.7776470 \\
\hline C & 3.5094660 & 0.3522540 & 3.0441430 \\
\hline $\mathrm{H}$ & 2.6036780 & 0.9993870 & 1.1910400 \\
\hline C & 1.9867210 & -0.3532020 & 4.7940820 \\
\hline $\mathrm{H}$ & -0.1169470 & -0.2441970 & 4.3353470 \\
\hline C & -4.3263630 & -4.4056120 & 1.2483200 \\
\hline $\mathrm{H}$ & -6.2755740 & -3.4726270 & 1.4532990 \\
\hline $\mathrm{H}$ & -2.2820200 & -5.0568690 & 0.9433030 \\
\hline C & -5.8021170 & 1.4739670 & -3.1316990 \\
\hline $\mathrm{H}$ & -5.8917010 & -0.5651580 & -3.8646960 \\
\hline $\mathrm{H}$ & -5.4873070 & 3.4021310 & -2.1882950 \\
\hline C & 4.0171540 & -0.8322710 & -1.3392340 \\
\hline $\mathrm{H}$ & 3.8262040 & -2.6504720 & -0.2143910 \\
\hline
\end{tabular}




$\begin{array}{lrrr}\mathrm{C} & 1.8015010 & -3.6138690 & 0.9092940 \\ \mathrm{O} & 4.1630390 & 1.1800620 & -2.5967080 \\ \mathrm{C} & -0.1690610 & 5.4359370 & 0.9763840 \\ \mathrm{H} & 0.4148380 & 5.5231190 & 3.0642000 \\ \mathrm{H} & -0.7332230 & 5.0357830 & -1.0793490 \\ \mathrm{C} & 3.2947040 & -0.1389990 & 4.3401420 \\ \mathrm{H} & 4.5280360 & 0.5127220 & 2.6771700 \\ \mathrm{H} & 1.8101440 & -0.7375410 & 5.8043010 \\ \mathrm{H} & -4.6813000 & -5.3959960 & 1.5521390 \\ \mathrm{H} & -6.4977480 & 1.8624320 & -3.8826250 \\ \mathrm{H} & 2.6087910 & -3.3256930 & 1.6073410 \\ \mathrm{H} & 1.0309620 & -4.1696540 & 1.4616780 \\ \mathrm{H} & 2.2190590 & -4.2627200 & 0.1168630 \\ \mathrm{C} & 3.5138100 & 2.3058750 & -3.1839250 \\ \mathrm{H} & -0.1563720 & 6.5230750 & 0.8462100 \\ \mathrm{H} & 4.1458460 & -0.3577160 & 4.9932730 \\ \mathrm{H} & 2.7235230 & 1.9955450 & -3.8910140 \\ \mathrm{H} & 4.3000320 & 2.8456500 & -3.7288640 \\ \mathrm{H} & 3.0779140 & 2.9714070 & -2.4163140 \\ \mathrm{C} & -0.8762010 & -1.0529870 & -2.1554400 \\ \mathrm{C} & -1.3485320 & -0.4928530 & -3.2858190 \\ \mathrm{H} & -0.5508340 & -2.1059070 & -2.2072830 \\ \mathrm{H} & -1.4091720 & -1.0573580 & -4.2287950 \\ \mathrm{H} & -1.6848110 & 0.5503510 & -3.3455310 \\ \mathrm{Br} & 5.8947130 & -1.1194500 & -1.6388380 \\ 77 & & & \\ \mathrm{Ar}= & \mathrm{ethene} \mathrm{TS} & & \\ \mathrm{C} & 1.9364370 & 0.4085910 & -1.7467350 \\ \mathrm{C} & 3.1528140 & -1.9191670 & -0.8088760 \\ \mathrm{C} & 1.1037130 & -0.6164480 & -1.2219970 \\ \mathrm{H} & 3.6572620 & -2.8134770 & -0.4382470 \\ \mathrm{Ni} & -0.6300570 & -0.1857350 & -0.4649260 \\ \mathrm{P} & -2.7949890 & -0.0899450 & -0.0304870 \\ \mathrm{P} & -0.2350940 & 0.8354470 & 1.4574620 \\ \mathrm{C} & -3.0113270 & 1.0074580 & 1.4878840 \\ \mathrm{C} & -3.5183390 & -1.6958830 & 0.5627480 \\ \mathrm{C} & -4.0736780 & 0.5247610 & -1.2136640 \\ \mathrm{C} & -1.8355810 & 0.7663320 & 2.4479190 \\ \mathrm{C} & 1.0766770 & 0.3363180 & 2.6574310 \\ \mathrm{C} & 0.0253660 & 2.6698860 & 1.2990160 \\ \mathrm{H} & -3.0018710 & 2.0553760 & 1.1405500 \\ \mathrm{H} & -3.9779510 & 0.8224490 & 1.9860000 \\ \mathrm{C} & -4.9034070 & -1.8799240 & 0.7432120\end{array}$




\begin{tabular}{|c|c|c|c|}
\hline $\mathrm{C}$ & -2.6375870 & -2.7494050 & 0.8746130 \\
\hline C & -4.9813990 & 1.5639800 & -0.9256640 \\
\hline C & -4.1018680 & -0.0678480 & -2.4947910 \\
\hline $\mathrm{H}$ & -1.9057500 & -0.2447990 & 2.8860150 \\
\hline $\mathrm{H}$ & -1.8377170 & 1.4986110 & 3.2729680 \\
\hline C & 2.4029010 & 0.2709890 & 2.1783400 \\
\hline C & 0.8184720 & -0.0223520 & 3.9953100 \\
\hline C & 0.5822500 & 3.4541220 & 2.3280490 \\
\hline C & -0.3818620 & 3.2979730 & 0.1052390 \\
\hline C & -5.3973040 & -3.0938640 & 1.2376430 \\
\hline $\mathrm{H}$ & -5.6009600 & -1.0771390 & 0.4809010 \\
\hline C & -3.1351280 & -3.9613210 & 1.3765320 \\
\hline $\mathrm{H}$ & -1.5617400 & -2.6164220 & 0.70 \\
\hline C & -5.9043360 & 1.9914000 & -1.8914540 \\
\hline $\mathrm{H}$ & -4.9823970 & 2.0450790 & 0.0569980 \\
\hline C & -5.0295470 & 0.3567560 & -3.4533920 \\
\hline $\mathrm{H}$ & -3.3785450 & -0.8496240 & -2.7440590 \\
\hline C & 3.4447600 & -0.1270290 & 3.0240110 \\
\hline $\mathrm{H}$ & 2.6204360 & 0.5284500 & 1.1365540 \\
\hline C & 1.8638550 & -0.4299870 & 4.8373490 \\
\hline $\mathrm{H}$ & -0.1992450 & 0.0167490 & 4.3949650 \\
\hline C & 0.7198130 & 4.8393 & 2.1675220 \\
\hline $\mathrm{H}$ & 0.9223820 & 2.9783210 & 3.2537740 \\
\hline C & -0.2527130 & 4.6855030 & -0.0502320 \\
\hline $\mathrm{H}$ & -0.7957350 & 2.6859800 & -0.7055770 \\
\hline C & -4.5134900 & -4.1352810 & 1.5590240 \\
\hline $\mathrm{H}$ & -6.4762800 & -3.2298790 & 1.3680020 \\
\hline $\mathrm{H}$ & -2.4439830 & -4.7758930 & 1.6178090 \\
\hline C & -5.9338500 & 1.3866310 & -3.1552750 \\
\hline $\mathrm{H}$ & -6.6060340 & 2.7973270 & -1.6510980 \\
\hline $\mathrm{H}$ & -5.0395830 & -0.1134850 & -4.4423030 \\
\hline C & 3.1786000 & -0.4794270 & 4.3557070 \\
\hline $\mathrm{H}$ & 4.4674470 & -0.1694440 & 2.6359980 \\
\hline $\mathrm{H}$ & 1.6474050 & -0.7042890 & 5.8754360 \\
\hline C & 0.2996910 & 5.4581280 & 0.9806380 \\
\hline $\mathrm{H}$ & 1.1599970 & 5.4383160 & 2.9719470 \\
\hline $\mathrm{H}$ & -0.5767880 & 5.1620520 & -0.9815560 \\
\hline $\mathrm{H}$ & -4.9014870 & -5.0841450 & 1.9441300 \\
\hline $\mathrm{H}$ & -6.6565090 & 1.7199830 & -3.9073010 \\
\hline $\mathrm{H}$ & 3.9940310 & -0.7950860 & 5.0147710 \\
\hline $\mathrm{H}$ & 0.4091570 & 6.5407090 & 0.8578560 \\
\hline C & -0.4348370 & -1.0356380 & -2.1864910 \\
\hline $\mathrm{H}$ & 1.4559490 & 1.3050530 & -2.1467210 \\
\hline
\end{tabular}




$\begin{array}{llll}\mathrm{C} & -0.6495100 & -0.4806680 & -3.4122670 \\ \mathrm{C} & 3.3304590 & 0.3020850 & -1.8109320 \\ \mathrm{O} & 4.1683320 & 1.2734830 & -2.3022130 \\ \mathrm{C} & 3.5682690 & 2.4559830 & -2.8292740 \\ \mathrm{H} & 2.9081320 & 2.2268160 & -3.6853890 \\ \mathrm{H} & 4.4039820 & 3.0812880 & -3.1704990 \\ \mathrm{H} & 2.9943420 & 2.9991130 & -2.0568460 \\ \mathrm{C} & 1.7572370 & -1.7844500 & -0.7388500 \\ \mathrm{O} & 0.9372580 & -2.7588080 & -0.1884200 \\ \mathrm{C} & 1.5427030 & -3.9957550 & 0.1865780 \\ \mathrm{H} & 2.2602110 & -3.8626300 & 1.0166410 \\ \mathrm{H} & 0.7209190 & -4.6430340 & 0.5217590 \\ \mathrm{H} & 2.0548660 & -4.4720550 & -0.6692940 \\ \mathrm{C} & 3.9320760 & -0.8860850 & -1.3377460 \\ \mathrm{H} & -0.5543110 & -2.1261050 & -2.1048240 \\ \mathrm{H} & -0.5094340 & 0.5861930 & -3.6206240 \\ \mathrm{H} & -0.9382200 & -1.0988180 & -4.2718600 \\ \mathrm{Br} & 5.8364050 & -1.0972950 & -1.4220020 \\ 89 & & & \\ \mathrm{Ar}= & \text { methylbenzothiophene reactant } & \\ \mathrm{Ni} & -0.3959630 & -0.2595510 & -0.0243600 \\ \mathrm{P} & -2.3437110 & -1.3542530 & -0.0699600 \\ \mathrm{P} & 0.5372050 & -2.1786780 & 0.5935810 \\ \mathrm{C} & -2.0911220 & -3.0267220 & 0.7526140 \\ \mathrm{C} & -2.7981900 & -1.8565630 & -1.7966470 \\ \mathrm{C} & -3.9314330 & -0.7199460 & 0.6170600 \\ \mathrm{C} & 1.3122700 & 0.6055920 & -0.2151990 \\ \mathrm{C} & -0.7126660 & -3.5589050 & 0.3380850 \\ \mathrm{C} & 0.7532090 & -2.2077250 & 2.4361800 \\ \mathrm{C} & 2.1367610 & -2.8571720 & -0.0224550 \\ \mathrm{H} & -2.8958330 & -3.7292370 & 0.4794290 \\ \mathrm{H} & -2.1227060 & -2.8735750 & 1.8449200 \\ \mathrm{C} & -4.0688190 & -2.3861540 & -2.0974810 \\ \mathrm{C} & -1.8332950 & -1.7499580 & -2.8161120 \\ \mathrm{C} & -4.4519340 & 0.4769720 & 0.0816080 \\ \mathrm{C} & -4.6238390 & -1.3614770 & 1.6617930 \\ \mathrm{C} & 2.0393210 & 0.3904480 & -1.4051000 \\ \mathrm{C} & 1.9016670 & 1.4205420 & 0.7657520 \\ \mathrm{H} & -0.4352930 & -4.4605080 & 0.9090840 \\ \mathrm{H} & -0.7158460 & -3.8174450 & -0.7346170 \\ \mathrm{C} & 1.4542970 & -3.2464770 & 3.0805760 \\ \mathrm{C} & 0.1583700 & -1.1950280 & 3.2118830 \\ \mathrm{C} & 3.3222200 & -2.1528490 & 0.2766030\end{array}$




\begin{tabular}{|c|c|c|c|}
\hline C & 2.2152750 & -4.0298870 & -0.7986760 \\
\hline $\mathrm{C}$ & -4.3657400 & -2.8105420 & -3.3985470 \\
\hline $\mathrm{H}$ & -4.8342520 & -2.4512780 & -1.3170720 \\
\hline & -2.1356890 & -2.1783420 & -4.1174820 \\
\hline $\mathrm{H}$ & -0.8519750 & -1.3173270 & -2.5894290 \\
\hline C & -5.6473800 & 1.0100260 & 0.5753210 \\
\hline r & -3.9093590 & 1.0004610 & -0.7115310 \\
\hline & -5.8201120 & -0.8206150 & 2.1560260 \\
\hline $\mathrm{H}$ & -4.2422920 & -2.2882110 & 2.0999590 \\
\hline $\mathrm{C}$ & 3.3071520 & 0.9637890 & -1.5976850 \\
\hline 0 & 1.4329610 & -0.4251850 & -2.3596910 \\
\hline C & 3.1762340 & 2.0050670 & 0.6066860 \\
\hline $\mathrm{H}$ & 1.3404660 & 1.6297680 & 1.6799950 \\
\hline C & 1.5502240 & -3.2724050 & 4.4775100 \\
\hline $\mathrm{H}$ & 1.9409860 & -4.0289610 & 2.4888280 \\
\hline $\mathrm{C}$ & 0.2527260 & -1.2253320 & 4.6108270 \\
\hline $\mathrm{H}$ & -0.37 & -0.3762960 & 2.7129610 \\
\hline C & 4.558 & -2.6234190 & -0.1820740 \\
\hline $\mathrm{H}$ & 3.2789380 & -1.2333020 & 0.8677700 \\
\hline $\mathrm{C}$ & 3.4558170 & -4.4957320 & -1.2577000 \\
\hline $\mathrm{H}$ & 1.31 & -4.5946040 & -1.0503200 \\
\hline C & -3.3988930 & -2.7086960 & -4.4 \\
\hline $\mathrm{H}$ & -5.35 & -3.2147510 & -3.62 \\
\hline $\mathrm{H}$ & -1.3847410 & -2.0850680 & -4.9089110 \\
\hline C & -6.3348800 & 0.3630630 & 1.6127090 \\
\hline $\mathrm{H}$ & -6.0349280 & 1.9432360 & 0.1551730 \\
\hline $\mathrm{H}$ & $-6.3<$ & -1.3301910 & 2.9680200 \\
\hline C & 3.8674810 & 1.7596800 & -0.5924420 \\
\hline $\mathrm{H}$ & 3.8769690 & 0.8079720 & -2.5157160 \\
\hline C & 2.1884340 & -0.7357480 & -3.5301610 \\
\hline $\mathrm{O}$ & 3.7888420 & 2.8028670 & 1.5414940 \\
\hline C & 0.9481780 & -2.2633030 & 5.2446430 \\
\hline $\mathrm{H}$ & 2.1021990 & -4.0802670 & 4.9692450 \\
\hline $\mathrm{H}$ & -0.2128460 & -0.4312330 & 5.2034260 \\
\hline C & 4.6295980 & -3.7957260 & -0.9481980 \\
\hline $\mathrm{H}$ & 5.4688350 & -2.0647160 & 0.0568550 \\
\hline $\mathrm{H}$ & 3.5021840 & -5.4124550 & -1.8549540 \\
\hline $\mathrm{H}$ & -3.6349370 & -3.0352470 & -5.4283550 \\
\hline $\mathrm{H}$ & -7.2676830 & 0.7849950 & 2.0007430 \\
\hline $\mathrm{H}$ & 3.1372380 & -1.2416490 & -3.2762500 \\
\hline $\mathrm{H}$ & 1.5633820 & -1.4189080 & -4.1218910 \\
\hline $\mathrm{H}$ & 2.4018260 & 0.1683450 & -4.1295260 \\
\hline C & 3.0553110 & 3.1128230 & 2.7271920 \\
\hline
\end{tabular}




$\begin{array}{lrrr}\mathrm{H} & 1.0276610 & -2.2843480 & 6.3364880 \\ \mathrm{H} & 5.5979560 & -4.1617120 & -1.3047170 \\ \mathrm{H} & 2.1078680 & 3.6295460 & 2.4936470 \\ \mathrm{H} & 3.7058270 & 3.7823980 & 3.3055710 \\ \mathrm{H} & 2.8425390 & 2.2054690 & 3.3212650 \\ \mathrm{C} & -1.1655700 & 1.4745160 & -0.1669140 \\ \mathrm{C} & -1.4509590 & 2.3704350 & -1.1785460 \\ \mathrm{C} & -2.0586200 & 3.6032510 & -0.7086920 \\ \mathrm{C} & -2.2178940 & 3.6470870 & 0.7068990 \\ \mathrm{C} & -2.7816260 & 4.7515060 & 1.3600640 \\ \mathrm{H} & -2.8935570 & 4.7630990 & 2.4493270 \\ \mathrm{C} & -3.1983480 & 5.8440790 & 0.5889220 \\ \mathrm{H} & -3.6394130 & 6.7171730 & 1.0811770 \\ \mathrm{C} & -3.0508080 & 5.8260410 & -0.8136240 \\ \mathrm{H} & -3.3790740 & 6.6894220 & -1.4022900 \\ \mathrm{C} & -2.4881800 & 4.7220560 & -1.4602160 \\ \mathrm{H} & -2.3767310 & 4.7227390 & -2.5501160 \\ \mathrm{C} & -1.1452630 & 2.1381090 & -2.6359260 \\ \mathrm{H} & -2.0625200 & 2.0778990 & -3.2517350 \\ \mathrm{H} & -0.5353600 & 2.9607670 & -3.0523550 \\ \mathrm{H} & -0.5813630 & 1.2048840 & -2.7733650 \\ \mathrm{~S} & -1.6236310 & 2.1452560 & 1.4190610 \\ \mathrm{Br} & 5.6057230 & 2.5291670 & -0.8740030 \\ 89 & & & \\ \mathrm{Ar}= & \text { methylbenzothiophene TS } & \\ \mathrm{C} & 1.9074590 & 1.5238330 & 0.7294160 \\ \mathrm{C} & 3.0241100 & 1.0705540 & -1.7835310 \\ \mathrm{C} & 1.0717340 & 0.9571320 & -0.2751650 \\ \mathrm{H} & 3.4970250 & 0.8722350 & -2.7471210 \\ \mathrm{Ni} & -0.4226500 & -0.2907780 & -0.0121950 \\ \mathrm{P} & -2.4163430 & -1.2706980 & -0.1095260 \\ \mathrm{P} & 0.4468210 & -2.1853510 & 0.7358620 \\ \mathrm{C} & -2.2517140 & -2.8710010 & 0.8739780 \\ \mathrm{C} & -2.9062640 & -1.9324590 & -1.7764570 \\ \mathrm{C} & -3.9757130 & -0.5066180 & 0.5125650 \\ \mathrm{C} & -0.8858640 & -3.5049020 & 0.5635660 \\ \mathrm{C} & 1.9747340 & -2.9681110 & 0.0558490 \\ \mathrm{C} & 0.7539270 & -2.1986660 & 2.5684240 \\ \mathrm{H} & -2.3170890 & -2.6083730 & 1.9444500 \\ \mathrm{H} & -3.0721580 & -3.5713900 & 0.6436150 \\ \mathrm{C} & -4.2216300 & -2.3432720 & -2.0686840 \\ \mathrm{C} & -1.9089600 & -2.0698700 & -2.7615680 \\ \mathrm{C} & -4.8503730 & -1.1344350 & 1.4208480\end{array}$




\begin{tabular}{|c|c|c|c|}
\hline C & -4.2757530 & 0.7960290 & 0.0628170 \\
\hline $\mathrm{H}$ & -0.8667770 & -3.8581910 & -0.4823180 \\
\hline 卜 & -0.6866280 & -4.3686020 & 1.2199230 \\
\hline & 3.1481210 & -2.1837260 & 0.0319810 \\
\hline C & 2.0183020 & -4.2741840 & -0.4708610 \\
\hline C & 1.5690160 & -3.1658410 & 3.1889700 \\
\hline C & 0.1171050 & -1.2271320 & 3.3649120 \\
\hline U & -4.5302970 & -2.8909270 & -3.3208630 \\
\hline H & -5.0113660 & -2.2220160 & -1.3199350 \\
\hline C & -2.2189960 & -2.6300480 & -4.0095040 \\
\hline $\mathrm{H}$ & -0.8930850 & -1.7202650 & -2.5457170 \\
\hline C & -6.0073730 & -0.4754230 & 1.8624410 \\
\hline $\mathrm{H}$ & -4.6387020 & -2.1421480 & 1.7910830 \\
\hline C & -5.4353460 & 1.4472630 & 0.4985130 \\
\hline $\mathrm{H}$ & -3.5894660 & 1.3071610 & -0.6205110 \\
\hline C & 4.3378110 & -2.7013630 & -0.4932500 \\
\hline $\mathbf{H}$ & 3.1302500 & -1.1618080 & 0.4248540 \\
\hline C & 3.2104020 & -4.7865710 & -1.0042050 \\
\hline $\mathrm{H}$ & 1.1257070 & -4.9066880 & -0.4648580 \\
\hline C & 1.7346410 & -3.1645080 & 4.5802080 \\
\hline $\mathrm{H}$ & 2.0871550 & -3.9153570 & 2.5817910 \\
\hline C & 0.2771650 & -1.2330 & 4.7579630 \\
\hline $\mathrm{H}$ & -0.4992480 & -0.4576440 & 2.8856550 \\
\hline C & -3.5290150 & -3.0404000 & -4.2917300 \\
\hline $\mathrm{H}$ & -5.5578940 & -3.1998670 & -3.5402940 \\
\hline $\mathrm{H}$ & -1.4366460 & -2.7393200 & -4.7683110 \\
\hline C & -6.3040540 & 0.8131480 & 1.3990690 \\
\hline $\mathrm{H}$ & -6.6788330 & -0.9740300 & 2.5696750 \\
\hline $\mathrm{H}$ & -5.6505790 & 2.4603720 & 0.1449410 \\
\hline C & 4.3723680 & -4.0038180 & -1.01 \\
\hline $\mathrm{H}$ & 5.2386410 & -2.0796030 & -0.5015670 \\
\hline $\mathrm{H}$ & 3.2294080 & -5.8045600 & -1.4078810 \\
\hline C & 1.0866870 & -2.2010400 & 5.3676200 \\
\hline $\mathrm{H}$ & 2.3758530 & -3.9171540 & 5.0512570 \\
\hline $\mathrm{H}$ & -0.2250300 & -0.4729460 & 5.3655400 \\
\hline $\mathrm{H}$ & -3.7720910 & -3.4697030 & -5.2692830 \\
\hline $\mathrm{H}$ & -7.2070250 & 1.3264870 & 1.7455430 \\
\hline $\mathrm{H}$ & 5.3026800 & -4.4059740 & -1.4280290 \\
\hline $\mathrm{H}$ & 1.2190430 & -2.2015590 & 6.4545840 \\
\hline $\mathrm{H}$ & 1.4626630 & 1.7331950 & 1.7035710 \\
\hline C & 3.2419880 & 1.8847260 & 0.5057100 \\
\hline $\mathrm{O}$ & 4.0618500 & 2.4474110 & 1.4515400 \\
\hline C & 3.4978210 & 2.7237850 & 2.7348040 \\
\hline
\end{tabular}




\begin{tabular}{|c|c|c|c|}
\hline $\mathrm{H}$ & 2.6496720 & 3.4272020 & 2.6597680 \\
\hline $\mathrm{H}$ & 4.3071090 & 3.1858470 & 3.3154510 \\
\hline $\mathrm{H}$ & 3.1657220 & 1.7983480 & 3.2387620 \\
\hline & 1.6944440 & 0.7020680 & -1.5384810 \\
\hline & 0.9387070 & -0.0103960 & -2.4570530 \\
\hline & 1.4740910 & -0.1656760 & -3.7724770 \\
\hline & 2.3874680 & -0.7869240 & -3.7670500 \\
\hline & 0.6945770 & -0.6726860 & -4.3570500 \\
\hline & 1.6960110 & 0.8134660 & -4.2347510 \\
\hline & 3.7896440 & 1.6680950 & -0.7763450 \\
\hline & -0.6227250 & 1.6025900 & -0.2037190 \\
\hline & -1.0339950 & 2.5627820 & -1.1432650 \\
\hline & -1.7265550 & 3.6895610 & -0.5587680 \\
\hline & -1.8607790 & 3.6052330 & 0.8595640 \\
\hline C & -2.5142100 & 4.5882390 & 1.6123740 \\
\hline & -2.6051650 & 4.4923910 & 2.6991820 \\
\hline & -3.0442700 & 5.7019690 & 0.9469200 \\
\hline & -3.5523670 & 6.4848570 & 1.5191890 \\
\hline C & -2.9193270 & 5.8176640 & -0.4 \\
\hline r & -3.3340390 & 6.6940610 & -0.9617940 \\
\hline & -2.2707010 & 4.8317230 & -1.1996400 \\
\hline ト & -2.1846780 & 4.9469680 & -2.2850020 \\
\hline$\varsigma$ & -1.1368030 & 2.113 & 8120 \\
\hline C & -0.7155010 & 2.5000870 & -2.6101680 \\
\hline ト & -1.3120610 & 3.2271090 & -3.1825490 \\
\hline ト & 0.3517110 & 2.7330750 & -2.7981000 \\
\hline r & -0.9002940 & 1.4999960 & -3.0286310 \\
\hline $\mathrm{Br}$ & 5.5965440 & 2.1839340 & -1.1535960 \\
\hline \multicolumn{4}{|c|}{83} \\
\hline \multicolumn{4}{|c|}{$\mathrm{Ar}=$ methylthiophene reactant } \\
\hline $\mathrm{Ni}$ & 0.5559230 & -0.2120510 & -0.0291960 \\
\hline $\mathrm{P}$ & 2.6875800 & 0.4548180 & -0.0649670 \\
\hline $\mathrm{F}$ & 0.0442410 & 1.8485840 & 0.6166310 \\
\hline $\mathrm{C}$ & 2.7921420 & 2.1398940 & 0.7654930 \\
\hline C & 3.2318440 & 0.8617380 & -1.7912570 \\
\hline $\mathrm{C}$ & 4.1133030 & -0.4961310 & 0.6135780 \\
\hline 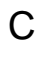 & -1.2942020 & -0.6988720 & -0.2307850 \\
\hline C & 1.5490600 & 2.9464810 & 0.3663030 \\
\hline C & -0.1492890 & 1.8966170 & 2.4615500 \\
\hline C & -1.3846390 & 2.8522560 & 0.0248010 \\
\hline $\mathrm{H}$ & 3.7209450 & 2.6646830 & 0.4867660 \\
\hline 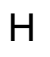 & 2.8017790 & 1.9773810 & 1.8569040 \\
\hline 0 & 4.5846610 & 1.1074510 & -2.0990900 \\
\hline
\end{tabular}




\begin{tabular}{|c|c|c|c|}
\hline $\mathrm{C}$ & 2.2597610 & 0.9740400 & -2.8033330 \\
\hline C & 4.3481480 & -1.7903490 & 0.1033650 \\
\hline C & 4.9564280 & 0.0059210 & 1.6236350 \\
\hline C & -1.9657010 & -0.3222560 & -1.4132600 \\
\hline C & -2.0373790 & -1.3873010 & 0.7428890 \\
\hline $\mathrm{H}$ & 1.4647520 & 3.8799970 & 0.9472010 \\
\hline $\mathrm{H}$ & 1.5992390 & 3.2098700 & -0.7040800 \\
\hline C & -0.6119520 & 3.0493080 & 3.1269990 \\
\hline C & 0.2244220 & 0.7696790 & 3.2174220 \\
\hline $\mathrm{C}$ & -2.6881190 & 2.4031920 & 0.3250600 \\
\hline C & -1.2245150 & 4.0266440 & -0.7362000 \\
\hline C & 4.9573900 & 1.4692100 & -3.3996420 \\
\hline $\mathrm{H}$ & 5.3512790 & 0.9997290 & -1.3245700 \\
\hline C & 2.6387390 & 1.3386160 & -4.1040890 \\
\hline $\mathrm{H}$ & 1.2099380 & 0.7597500 & -2.5713600 \\
\hline C & 5.4159200 & -2.5550080 & 0.5861280 \\
\hline $\mathrm{H}$ & 3.6823370 & -2.2045930 & -0.6600150 \\
\hline C & 6.0212090 & -0.7678690 & 2.1086050 \\
\hline $\mathrm{H}$ & 4.7957640 & 1.0039770 & 2.0413470 \\
\hline C & -3.3251570 & -0.6195240 & -1.6060100 \\
\hline $\mathrm{O}$ & -1.2077140 & 0.3625950 & -2.3629430 \\
\hline C & -3.4055490 & -1.6935820 & 0.58 \\
\hline $\mathrm{H}$ & -1.5282090 & -1.7215300 & 1.6504160 \\
\hline C & -0.6908390 & 3.0731640 & 4.5250860 \\
\hline $\mathrm{H}$ & -0.9270350 & 3.9256240 & 2.5506800 \\
\hline C & 0.1477950 & 0.7971070 & 4.6175010 \\
\hline $\mathrm{H}$ & 0.5686890 & -0.1339320 & 2.7006660 \\
\hline C & -3.8037140 & 3.1245290 & -0.1172330 \\
\hline $\mathrm{H}$ & -2.8319860 & 1.4860670 & 0.9039790 \\
\hline C & -2.3450870 & 4.7442950 & -1.17 \\
\hline $\mathrm{H}$ & -0.2266370 & 4.3967710 & -0.9885250 \\
\hline C & 3.9845600 & 1.5870170 & -4.4037940 \\
\hline $\mathrm{H}$ & 6.0118240 & 1.6520360 & -3.6320560 \\
\hline $\mathrm{H}$ & 1.8800320 & 1.4158400 & -4.8898550 \\
\hline C & 6.2547660 & -2.0472810 & 1.5888620 \\
\hline $\mathrm{H}$ & 5.5833490 & -3.5591410 & 0.1841530 \\
\hline $\mathrm{H}$ & 6.6697290 & -0.3648850 & 2.8936020 \\
\hline C & -4.0349790 & -1.2953410 & -0.6073610 \\
\hline $\mathrm{H}$ & -3.8533410 & -0.3378410 & -2.5189780 \\
\hline C & -1.8881820 & 0.8389000 & -3.5234370 \\
\hline O & -4.1667850 & -2.3606520 & 1.5135130 \\
\hline C & -0.3095310 & 1.9481790 & 5.2723300 \\
\hline $\mathrm{H}$ & -1.0571590 & 3.9713170 & 5.0333360 \\
\hline
\end{tabular}




\begin{tabular}{|c|c|c|c|}
\hline & & 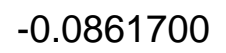 & \\
\hline C & .6361340 & 4.2967910 & .8682300 \\
\hline & -4.8081060 & 7617470 & 4 \\
\hline & -2.2049740 & 6591900 & 7642120 \\
\hline & 4.2786080 & 8639050 & 5.4215860 \\
\hline & 7.0861200 & 2.6504610 & .9682430 \\
\hline & -2.7114650 & 1.5256320 & -3.2562430 \\
\hline & -1.1385460 & 1.3870350 & -4.1109580 \\
\hline & -2.2863400 & 0.0070960 & -4.133292 \\
\hline & -3.5101070 & -2.8243460 & 2.693645 \\
\hline & -0.37 & 1.9686250 & 6.3651170 \\
\hline & -4.51 & 4.8592550 & -1.2 \\
\hline & -2.68 & -3.5220020 & 5800 \\
\hline & -4.28 & -3.35 & 3.2693100 \\
\hline & -3.11 & 1760 & 3.2942990 \\
\hline & 0.9 & -2.07 & 7490 \\
\hline & 1.0 & 39840 & 4200 \\
\hline & 1.2 & -2.8 & 6650 \\
\hline & 1.3 & -4.3 & 6500 \\
\hline & 1.4 & -4.4507950 & 2040 \\
\hline & 1.4 & -5.1 & 0350 \\
\hline & 1.7 & -5.3 & 1790 \\
\hline & $0.7 c$ & -2.6537860 & 51420 \\
\hline П & 1.73 & 3540 & -3.2941660 \\
\hline П & 0.11 & -3.3 & -3.1771490 \\
\hline & 0.34 & -1.6563840 & -2.8103120 \\
\hline & $-5.8 \varsigma$ & -1.6875020 & -0.889270 \\
\hline 83 & & & \\
\hline \multicolumn{4}{|c|}{$\mathrm{Ar}=$ methylthiphene $\mathrm{TS}$} \\
\hline 0 & -2.0887530 & -1.3254370 & 0.9658710 \\
\hline C & -3.0472420 & -1.0973910 & -1.6414630 \\
\hline C & -1.1384490 & -1.1136930 & -0.0732480 \\
\hline $\mathrm{H}$ & -3.4520870 & -0.9794400 & -2.6484450 \\
\hline $\mathrm{Ni}$ & 0.5789900 & -0.1845560 & 0.0398620 \\
\hline $\mathrm{P}$ & 2.7327310 & 0.3646420 & -0.1435220 \\
\hline$P$ & 0.1053920 & 1.9380230 & 0.4548100 \\
\hline C & 2.8862220 & 2.1014900 & 0.5759270 \\
\hline C & 3.3484760 & 0.6488650 & -1.8750750 \\
\hline C & 4.1128880 & -0.5754460 & 0.6432920 \\
\hline C & 1.6718990 & 2.9317920 & 0.1299420 \\
\hline C & -1.2344470 & 2.8892810 & -0.3882270 \\
\hline C & -0.1997260 & 2.2975980 & 2.2525480 \\
\hline 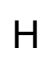 & 2.8992540 & 2.0014570 & 1.6755370 \\
\hline
\end{tabular}




\begin{tabular}{|c|c|c|c|}
\hline $\mathrm{H}$ & 3.8277210 & 2.5852750 & 0.2656230 \\
\hline C & 4.7192240 & 0.7129680 & -2.1931350 \\
\hline C & 2.3973610 & 0.8535590 & -2.8941870 \\
\hline C & 5.1210710 & 0.0187020 & 1.4278040 \\
\hline C & 4.1264380 & -1.9732180 & 0.4566920 \\
\hline $\mathrm{H}$ & 1.7248410 & 3.1165650 & -0.9573160 \\
\hline $\mathrm{H}$ & 1.6447910 & 3.9084960 & 0.6416700 \\
\hline $\mathrm{C}$ & -2.5380960 & 2.3494880 & -0.3440290 \\
\hline$C$ & -1.0177800 & 4.0872050 & -1.0978600 \\
\hline C & -0.8076700 & 3.49 & 2.6902670 \\
\hline C & 0.2275910 & 1.3564390 & 3.2092980 \\
\hline C & 5.1298330 & 0.9874250 & -3.5045120 \\
\hline$\vdash$ & 5.4696320 & 0.5354200 & -1.4157790 \\
\hline 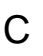 & 2.8120200 & 5570 & -4.2026340 \\
\hline $\mathrm{H}$ & 1.3312310 & 0.7690490 & -2.6553370 \\
\hline C & 6.1293400 & -0.7677740 & 2.0042690 \\
\hline $\mathrm{H}$ & 5.1301850 & 1.1000940 & 1.5949000 \\
\hline 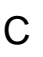 & 5.1405790 & -2.75 & 1.0242700 \\
\hline $\mathrm{H}$ & 3.3301250 & -2.45 & -0.1222960 \\
\hline C & -3.5989050 & 3.0020650 & -0.9828790 \\
\hline $\mathrm{H}$ & -2.7240790 & 1.4120510 & 0.1904010 \\
\hline C & -2.0819900 & 4.7340460 & -1.7436680 \\
\hline $\mathrm{H}$ & -0.0191060 & 4.53 & -1.1488790 \\
\hline C & -0.9748450 & 3.73 & 4.0589690 \\
\hline $\mathrm{H}$ & -1.1639560 & 4.2233030 & 1.9585580 \\
\hline C & 0.0671050 & 1.6108610 & 4.5788740 \\
\hline $\mathrm{H}$ & 0.6793980 & 0.41 & 2.8736780 \\
\hline C & 4.1777860 & 1.2080370 & -4.5105840 \\
\hline $\mathrm{H}$ & 6.1983320 & 1.0274160 & -3.7419060 \\
\hline $\mathrm{H}$ & 2.0658420 & 1.3066750 & -4.9873620 \\
\hline C & 6.1441250 & -2.1538530 & 1.7991760 \\
\hline $\mathrm{H}$ & 6.9064570 & -0.2932280 & 2.6130050 \\
\hline $\mathrm{H}$ & 5.1373120 & -3.8375090 & 0.8713860 \\
\hline C & -3.3741840 & 4.1956300 & -1.6851250 \\
\hline $\mathrm{H}$ & -4.6033000 & 2.5693970 & -0.9368110 \\
\hline $\mathrm{H}$ & -1.8982420 & 5.6658380 & -2.2892780 \\
\hline C & -0.5348210 & 2.8022690 & 5.0058240 \\
\hline $\mathrm{H}$ & -1.4545960 & 4.6674630 & 4.3874820 \\
\hline $\mathrm{H}$ & 0.4053410 & 0.8710980 & 5.3120100 \\
\hline $\mathrm{H}$ & 4.5008180 & 1.4243810 & -5.5342400 \\
\hline $\mathrm{H}$ & 6.9322860 & -2.7667620 & 2.2488110 \\
\hline $\mathrm{H}$ & -4.2042890 & 4.7027170 & -2.1878120 \\
\hline $\mathrm{H}$ & -0.6680640 & 2.9985350 & 6.0748370 \\
\hline
\end{tabular}




$\begin{array}{cccc}\mathrm{H} & -1.7122040 & -1.4517030 & 1.9825900 \\ \mathrm{C} & -3.4653590 & -1.4418660 & 0.7365630 \\ \mathrm{O} & -4.3995750 & -1.6588760 & 1.7194620 \\ \mathrm{C} & -3.9263490 & -1.8148400 & 3.0577600 \\ \mathrm{H} & -3.2410560 & -2.6766960 & 3.1461220 \\ \mathrm{H} & -4.8230870 & -1.9960700 & 3.6650870 \\ \mathrm{H} & -3.4175850 & -0.9021000 & 3.4167840 \\ \mathrm{C} & -1.6743830 & -0.9669030 & -1.3915760 \\ \mathrm{O} & -0.7678700 & -0.5980380 & -2.3763080 \\ \mathrm{C} & -1.2320850 & -0.5853860 & -3.7264760 \\ \mathrm{H} & -1.9957250 & 0.1971100 & -3.8859760 \\ \mathrm{H} & -0.3521490 & -0.3649810 & -4.3459550 \\ \mathrm{H} & -1.6454430 & -1.5679700 & -4.0193890 \\ \mathrm{C} & -3.9367680 & -1.3431650 & -0.5899090 \\ \mathrm{C} & 0.3964180 & -2.0905170 & 0.1768180 \\ \mathrm{C} & 0.5985990 & -3.2608330 & -0.5851490 \\ \mathrm{~S} & 0.7785520 & -2.4550020 & 1.8906340 \\ \mathrm{C} & 1.0301050 & -4.3780480 & 0.2014640 \\ \mathrm{C} & 1.1665780 & -4.1219870 & 1.5454070 \\ \mathrm{H} & 1.2199490 & -5.3639490 & -0.2353290 \\ \mathrm{H} & 1.4936660 & -4.7912750 & 2.3409990 \\ \mathrm{C} & 0.3132950 & -3.4011350 & -2.0553110 \\ \mathrm{H} & -0.7749160 & -3.3560200 & -2.2569080 \\ \mathrm{H} & 0.7787000 & -2.6007270 & -2.6509390 \\ \mathrm{H} & 0.6768120 & -4.3712710 & -2.4309860 \\ \mathrm{Br} & -5.8049790 & -1.5502710 & -0.9692950\end{array}$




\section{References}

1. E.A. Collins, P. Garcia-Losada, C. Hamdouchi, P.A. Hipskind, J. Lu, T. Takakuwa, WO/2006/107784 A1.

2. S.R Lee, J.W.G Bloom, S.E. Wheeler, A.J. McNeil, Dalton Trans., 2013, 42, 4218-4222.

${ }^{3}$ B. E. Love, E. G. Jones, J. Org Chem., 1999, 64, 3755-3756.

${ }^{4}$ http://collum.chem.cornell.edu/documents/Fitting_to_Differential_Equ_IgorPro.pdf Accessed December 2016

${ }^{5}$ (a) A. D. Becke, Phys. Rev. A 1988, 38, 3098-3100; (b) J. P. Perdew, Phys. Rev. B 1986, 33, 8822-8824.

6 (a) K. Raghavachari, J. S. Binkley, R. Seeger, J. A. Pople, J. Chem. Phys. 1980, 72, 650-654; (b) A. D. McLean, G. S. Chandler, J. Chem. Phys. 1980, 72, 5639-5648; (c) T. Clark, J. Chandrasekhar, G. W. Spitznagel, P. v. R. Schleyer, J. Comp. Chem. 1983, 4, 294-301.

7 (a) M. Dolg, U. Wedig, H. Stoll and H. Preuss, J. Chem. Phys., 1987, 86, 866-872; (b) J. M. L. Martin and A. Sundermann, J. Chem. Phys., 2001, 114, 3408-3420. 